\title{
The bacterial actin-like cell division protein FtsA forms curved antiparallel double filaments upon binding of Fts $\mathbf{N}$
}

Tim Nierhaus ${ }^{1}$, Stephen H McLaughlin¹, Frank Bürmann¹, Danguole KureisaiteCiziene$^{1}$, Sarah Maslen ${ }^{1,2}$, Mark J Skehel ${ }^{1,2}$, Conny WH Yu${ }^{1}$, Stefan MV Freund ${ }^{1}$, Louise FH Funke ${ }^{1}$, Jason W Chin ${ }^{1}$, Jan Löwe ${ }^{1 *}$

${ }^{1}$ MRC Laboratory of Molecular Biology, Cambridge, UK.

2 Present address: The Francis Crick Institute, London, UK.

*Corresponding author: Jan Löwe, MRC Laboratory of Molecular Biology, Cambridge Biomedical Campus, Francis Crick Avenue, Cambridge CB2 OQH, UK, email: jyl@mrc-Imb.cam.ac.uk, phone: +44 (0)1223 267064

Keywords: cell division; divisome; FtsA; FtsN; MreB; cryo-EM; X-ray crystallography 
bioRxiv preprint doi: https://doi.org/10.1101/2021.11.08.467742; this version posted November 8 , 2021. The copyright holder for this preprint (which was not certified by peer review) is the author/funder, who has granted bioRxiv a license to display the preprint in perpetuity. It is made available under aCC-BY 4.0 International license.

FtsA-FtsN antiparallel double filaments

Nierhaus 2021

\section{ABSTRACT}

Cell growth and division of walled bacteria depend on the synthesis and remodelling of peptidoglycan (PG). These activities are carried out by two multiprotein complexes, the elongasome and the divisome during cell elongation and division, respectively. Filaments of tubulin-like FtsZ form the cytoplasmic scaffold for divisome assembly, the Z-ring. In E. coli, the actin homologue FtsA anchors the Z-ring to the membrane and recruits downstream divisome components, including bitopic FtsN. FtsN is recruited late and activates the periplasmic PG synthase FtsWI. To start unravelling the activation mechanism involving FtsA and FtsN, we showed that E. coli FtsA forms antiparallel double filaments on lipid monolayers when also binding FtsN's cytoplasmic tail, and that Vibrio maritimus FtsA crystallised as an equivalent double filament. We structurally located the FtsA-FtsN interaction site in FtsA's IA-IC interdomain cleft and confirmed FtsA double filament formation in vivo using site-specific cysteine crosslinking. FtsA-FtsN double filaments reconstituted on and in liposomes preferred negative Gaussian curvature, as was previously shown for the elongasome's actin, MreB. MreB filaments serve as curvature-sensing "rudders", orienting insertion of PG around the cell's circumference. We propose that curved antiparallel FtsA double filaments function similarly in the divisome: FtsA filaments, together with dynamic FtsZ filaments orient and concentrate cell-constricting septal PG synthesis in the division plane. 
bioRxiv preprint doi: https://doi.org/10.1101/2021.11.08.467742; this version posted November 8, 2021. The copyright holder for this preprint (which was not certified by peer review) is the author/funder, who has granted bioRxiv a license to display the preprint in perpetuity. It is made available under aCC-BY 4.0 International license.

FtsA-FtsN antiparallel double filaments

Nierhaus 2021

\section{INTRODUCTION}

In non-spherical, walled bacteria, cell shape is determined by the peptidoglycan sacculus, the load-bearing structure counteracting turgor pressure (Typas et al., 2011). Insertion of new glycan strands into the sacculus is orchestrated by two related multiprotein complexes: the divisome, acting in cell division, and the elongasome (or rod complex), acting in cell elongation (Szwedziak and Löwe, 2013). In Escherichia coli, both complexes span the entire cell envelope and contain the cytoplasmic, membrane-binding and filament-forming actin homologues FtsA (divisome) and MreB (elongasome) (Pichoff and Lutkenhaus, 2005; Salje et al., 2011).

In E. coli and many other bacteria, FtsA is the main membrane anchor for the cell division ring, the Z-ring, which initiates and organises cell division (Geissler et al., 2003; Pichoff and Lutkenhaus, 2002). The Z-ring is mainly formed by filaments of the tubulin homologue FtsZ (Bisson-Filho et al., 2017; Nogales et al., 1998; Yang et al., 2017). FtsZ treadmilling dynamics, driven by FtsZ's GTPase activity, were shown to be essential for the initial condensation of FtsZ filaments into the Z-ring, but seem to become dispensable after partial constriction of the septum (Monteiro et al., 2018; Squyres et al., 2021; Whitley et al., 2021).

Apart from localising FtsZ to the membrane, FtsA is also involved in the recruitment of downstream divisome components such as FtsK, FtsN and potentially FtsQ (Du and Lutkenhaus, 2017; Karimova et al., 2005). Together with the bitopic membrane protein FtsN, FtsA is required for divisome integrity (Pichoff et al., 2018). FtsN assembles last into the divisome and activates the bipartite septal PG synthase FtsWI via FtsQLB (Gerding et al., 2009; Li et al., 2021; Liu et al., 2015; Marmont and Bernhardt, 2020; 
bioRxiv preprint doi: https://doi.org/10.1101/2021.11.08.467742; this version posted November 8, 2021. The copyright holder for this preprint (which was not certified by peer review) is the author/funder, who has granted bioRxiv a license to display the preprint in perpetuity. It is made available under aCC-BY 4.0 International license.

FtsA-FtsN antiparallel double filaments

Nierhaus 2021

Tsang and Bernhardt, 2015), and possibly also PBP1b (Boes et al., 2019; Müller et al., 2007).

Small amounts of FtsN are recruited early to the divisome in a FtsA-dependent manner (Busiek and Margolin, 2014). The FtsA-FtsN interaction is known to involve FtsA's for actin-like proteins uniquely positioned IC domain and FtsN's cytoplasmic tail, which comprises $~ 32$ amino acids in E. coli (Baranova et al., 2020; Busiek et al., 2012; Pichoff et al., 2015). Two FtsN suppressor mutations in FtsA located in its IC domain (Bernard et al., 2007; Liu et al., 2015) further support the idea that FtsN binds the IC domain of FtsA. In FtsN, a conserved stretch of basic amino acids in its cytoplasmic tail is required for interaction with FtsA in vitro (Baranova et al., 2020; Busiek et al., 2012). In a zipA null background, in which the FtsA-FtsN interaction becomes essential, mutation of the basic stretch in FtsN was however permissible, whereas a D5N mutation was not (Pichoff et al., 2015). It has been proposed that interaction with FtsN depolymerises FtsA and, thereby, allows recruitment of downstream divisome components via binding sites that were (partially) occluded in the FtsA polymer (Pichoff et al., 2015).

However, little else has been reported regarding FtsA's polymerisation state in the divisome and its interaction sites with other divisome proteins. Despite the uniqueness of FtsA's IC domain amongst the actin-like proteins (van den Ent and Löwe, 2000), FtsA was shown to form single protofilaments that recapitulate some structural features of bona fide actin protofilaments (Szwedziak et al., 2012). Double filaments were shown to be the smallest functional unit of all other known actin homologues (Wagstaff and Löwe, 2018) and, indeed, Thermotoga maritima FtsA was shown to 
bioRxiv preprint doi: https://doi.org/10.1101/2021.11.08.467742; this version posted November 8, 2021. The copyright holder for this preprint (which was not certified by peer review) is the author/funder, who has granted bioRxiv a license to display the preprint in perpetuity. It is made available under aCC-BY 4.0 International license.

FtsA-FtsN antiparallel double filaments

Nierhaus 2021

form double filaments (Szwedziak et al., 2012). Furthermore, several mutations in E. coli FtsA, originally described as ZipA suppressor mutations, were shown to facilitate double filament formation of FtsA on supported lipid monolayers (Schoenemann et al., 2018).

In contrast, the actin-like protein of the elongasome, MreB, adopts the canonical actinlike fold (van den Ent et al., 2001). MreB binds to membranes directly and forms curved antiparallel double filaments (Hussain et al., 2018; Salje et al., 2011; van den Ent et al., 2014). This enables a curvature-sensing mechanism that allows MreB filaments to align with the axis of highest principal curvature, the short axis of the cell in the case of rod-shaped cells, such as Bacillus subtilis (Hussain et al., 2018; Wong et al., 2019). Hence, the elongasome uses MreB double filaments as "rudders" to direct movement of its bipartite PG synthase RodA-PBP2 (equivalent to FtsWI in the divisome) and, thereby, directs insertion of new PG strands around the cell circumference (Dion et al., 2019; Garner et al., 2011). It is thought that the radially inserted PG hoops enforce rod shape by mechanically limiting cell width expansion.

Here, we showed that FtsA from the Gram-negative bacterium Vibrio maritimus crystallised as antiparallel double filaments. Using supported lipid monolayers, we demonstrated that E. coli FtsA forms very similar antiparallel double filaments upon binding the short, cytoplasmic tail of FtsN. Using crystallography, we showed that FtsN binds FtsA in the IA-IC interdomain cleft. Furthermore, we demonstrated the in vivo significance of FtsA double filaments by site-specific cysteine cross-linking in E. coli. FtsA-FtsN filaments reconstituted on and in liposomes preferred negative Gaussian curvature, suggesting that FtsA double filaments in the divisome sense curvature 
bioRxiv preprint doi: https://doi.org/10.1101/2021.11.08.467742; this version posted November 8,2021 . The copyright holder for this preprint (which was not certified by peer review) is the author/funder, who has granted bioRxiv a license to display the preprint in perpetuity. It is made available under aCC-BY 4.0 International license.

FtsA-FtsN antiparallel double filaments

Nierhaus 2021

using a similar mechanism as has been proposed for MreB filaments in the elongasome. We therefore propose that FtsA double filaments provide a curvatureguided mechanism to orient cell-constricting septal PG synthesis, which is further organised by dynamic FtsZ filaments into the required ring structure at the division site. 
bioRxiv preprint doi: https://doi.org/10.1101/2021.11.08.467742; this version posted November 8,2021 . The copyright holder for this preprint (which was not certified by peer review) is the author/funder, who has granted bioRxiv a license to display the preprint in perpetuity. It is made available under aCC-BY 4.0 International license.

FtsA-FtsN antiparallel double filaments

Nierhaus 2021

\section{RESULTS}

\section{Vibrio maritimus FtsA crystallises as an antiparallel double filament}

Previously obtained structures of FtsA are limited to the two organisms Staphylococcus aureus and Thermotoga maritima (Fujita et al., 2014; Szwedziak et al., 2012; van den Ent and Löwe, 2000). Encouraged by a recent study reporting double filaments formed by E. coli FtsA (Schoenemann et al., 2018), we reasoned that further FtsA crystal structures, especially from Gram-negative organisms such as E. coli, might provide new insights into the architecture of FtsA filaments and their function in the divisome.

We solved the crystal structure of C-terminally truncated FtsAs from E. coli (EcFtsA, Protein Data Bank (PDB) identifier: 7Q6D) and the closely related Gram-negative bacterium Xenorhabdus poinarii (PDB 7Q6G, $90 \%$ identity of XpFtsA to EcFtsA) and Vibrio maritimus (PDB 7Q6F, $70 \%$ identity of VmFtsA to EcFtsA) (Supplementary Table $T$ 1). The EcFts $A^{1-405}$ and $\mathrm{XpFts}^{1-396}$ structures showed single protofilaments with a loose longitudinal contact between the IIA and IIB subdomains (Supplementary Figure S1a). In contrast, VmFtsA ${ }^{1-396}$ crystallised as straight, antiparallel double filaments, with lateral contacts formed by the IC domain, which among actins is unique to FtsA (van den Ent and Löwe, 2000) (Figure 1a). The longitudinal interface contact between the IIA-IIB domains was tight in both protofilaments, as was the case for TmFtsA bound to ATP-y-S (PDB 4A2B) (Szwedziak et al., 2012) (Supplementary Figure S1a). We noticed that the position of the IC domain is variable within the FtsA monomers across FtsA structures (Supplementary Figure S1b). Positioning of the IC domain did neither correlate with species nor the presence of continuous protofilaments within the crystal, as analysed for PDB 1E4F, 4A2B and 7Q6F. 
bioRxiv preprint doi: https://doi.org/10.1101/2021.11.08.467742; this version posted November 8,2021 . The copyright holder for this preprint (which was not certified by peer review) is the author/funder, who has granted bioRxiv a license to display the preprint in perpetuity. It is made available under aCC-BY 4.0 International license.

FtsA-FtsN antiparallel double filaments

Nierhaus 2021

The lateral interface in the VmFtsA double filament is almost exclusively formed by contacts between IC domains (Figure 1b). Each FtsA monomer contacts two subunits in the opposing protofilament, forming the $\mathrm{FtsA}_{\mathrm{i}}-\mathrm{Fts} \mathrm{A}_{\mathrm{i}^{*}}$ and $\mathrm{Fts} \mathrm{A}_{\mathrm{i}}-\mathrm{Fts} \mathrm{A}_{\mathrm{i}^{*}-1}$ lateral interfaces. Both interfaces have local twofold (C2) symmetry as indicated in Figure $1 \mathrm{~b}$. The VmFtsA double filament is wider than the MreB double filament (PDB 4CZJ) (van den Ent et al., 2014), which is, like FtsA filaments, comprised of two antiparallel protofilaments (Supplementary Figure S1c). The membrane-proximal side of FtsA and MreB double filaments is flat. ZipA suppressor mutations in E. coli FtsA (including Fts $A^{R 286 W}$, also known as $F t s A^{*}$ ), which were described to also affect filament architecture (Schoenemann et al., 2018), correspond to residues in subunit interfaces in the VmFtsA double filament structure (Figure 1c). Interestingly, the FtsN suppressor mutations E124A (Bernard et al., 2007) and I143L (Liu et al., 2015) described for E. coli FtsA also map to subunit interfaces in the VmFtsA double filament structure (Figure 1c).

\section{E. coli FtsA forms antiparallel double filaments upon binding the cytoplasmic tail of FtsN, EcFtsN ${ }^{1-32}$}

As described previously (Krupka et al., 2017), we found that E. coli FtsA forms "minirings" on supported lipid monolayers (Figure 2g, "WT + no peptide"). Given that filament architecture mutations and FtsN suppressor mutations in E. coli FtsA map to lateral interfaces in the VmFtsA double filament (Figure 1c), we hypothesised that FtsN could induce double filament formation of E. coli FtsA. The short, cytoplasmic tail of FtsN (comprising $\sim 32$ amino acids in E. coli) (Supplementary Figure S2f) interacted with FtsA as had been shown previously (Busiek et al., 2012; Busiek and Margolin, 
bioRxiv preprint doi: https://doi.org/10.1101/2021.11.08.467742; this version posted November 8, 2021. The copyright holder for this preprint (which was not certified by peer review) is the author/funder, who has granted bioRxiv a license to display the preprint in perpetuity. It is made available under aCC-BY 4.0 International license.

FtsA-FtsN antiparallel double filaments

Nierhaus 2021

2014; Pichoff et al., 2015). Using surface plasmon resonance (SPR), we showed that EcFtsN ${ }^{1-32}$ binds EcFtsA and EcFtsA ${ }^{1-405}$, a C-terminal truncation of EcFtsA lacking the amphipathic membrane binding helix, with dissociation constants $\left(\mathrm{K}_{\mathrm{d}}\right)$ of $0.8 \mu \mathrm{M}$ and $2.0 \mu \mathrm{M}$, respectively (Figure $2 \mathrm{a}$ ). The interaction between $V$. maritimus Fts $\mathrm{A}^{1-396}$ and $\mathrm{Fts}^{1-29}$ was about three-fold weaker than the $\mathrm{EcFts}^{1-405}-\mathrm{EcFts}^{1-32}$ interaction $^{1}$ (Supplementary Figure S2a). Since cross-linking of FtsA to the flow cell surface in SPR might affect FtsA polymerisation, we also probed the FtsA-FtsN interaction in solution using fluorescence polarisation (FP), for which C-terminally truncated FtsA was titrated into fluorescently labelled FtsN peptide. FP data were fitted to a two-step model with $\mathrm{K}_{\mathrm{d}} \mathrm{S}$ of about $0.016 \mu \mathrm{M}$ and $11 \mu \mathrm{M}$ for the EcFtsA ${ }^{1-405}-\mathrm{FtsN}^{1-32-C-A t t o} 495$ interaction (Figure 2b). Again, the $\mathrm{VmFtsA}^{1-396}-\mathrm{FtsN}^{1-29}$ interaction was about four-fold weaker for the first binding event (Supplementary Figure S2b). Next, we subjected the system to analytical ultracentrifugation using a fluorescence detection system (FDS$A \cup C)$ to characterise the two binding events of the FtsA-FtsN interaction. FDS-AUC showed that both binding events are accompanied by formation of higher order FtsAFtsN aggregates or polymers, indicating that the cytoplasmic FtsN peptide not only binds to FtsA but could also facilitate FtsA polymerisation (Figure 2c; Supplementary Figure S2c). Using a co-pelleting assay, for which cytoplasmic FtsN peptide was titrated into truncated FtsA, we showed that FtsN peptide indeed induces FtsA polymerisation, as apparent by the increased fraction of FtsA in the pellet at higher concentrations of FtsN peptide (Figure 2d; Supplementary Figure S2d).

Given that the cytoplasmic peptide of FtsN induces FtsA polymerisation, we next investigated the architecture of those polymers using negative stain electron microscopy (EM). Both EcFtsA-FtsN ${ }^{1-32}$ and $V m F t s A-F t s N^{1-29}$ formed short double 
bioRxiv preprint doi: https://doi.org/10.1101/2021.11.08.467742; this version posted November 8, 2021. The copyright holder for this preprint (which was not certified by peer review) is the author/funder, who has granted bioRxiv a license to display the preprint in perpetuity. It is made available under aCC-BY 4.0 International license.

FtsA-FtsN antiparallel double filaments

Nierhaus 2021

filaments on supported lipid monolayers (Figure 2g, "WT”; Supplementary Figure S2e). Electron cryo-microscopy (cryo-EM) imaging and subsequent 2D averaging of EcFtsA-FtsN ${ }^{1-32}$ double filaments on lipid monolayers showed that EcFtsA-Fts $\mathrm{N}^{1-32}$ double filaments have very similar architecture to the VmFtsA ${ }^{1-396}$ double filaments determined by crystallography (PDB 7Q6F) (Figure 2e). To corroborate, we designed a lateral interface mutant of $E$. coli FtsA based on the VmFtsA double filament structure: EcFtsA $\mathrm{A}^{\mathrm{M} 66 \mathrm{E}, \mathrm{R} 153 \mathrm{D}}$ (Figure 2f, right). The lipid monolayer assay showed that EcFtsA $^{\mathrm{M} 96 \mathrm{E}, \mathrm{R} 153 \mathrm{D}}$ was indeed deficient in EcFtsN ${ }^{1-32}$-dependent double filament formation (Figure 2f).

The short cytoplasmic tail of FtsN harbours two sequence motifs that are conserved among E. coli and related proteobacteria with similar FtsA and FtsN sequences: a conserved ${ }^{3} \mathrm{R} / \mathrm{KDY}^{6}$ (E. coli amino acid positions) motif near the $\mathrm{N}$-terminus (Pichoff et al., 2015) and two to three stretches of basic amino acids, the most prominent of which in E. coli FtsN is ${ }^{16} \mathrm{RRKK}^{19}$ (Busiek et al., 2012) (Supplementary Figure S2f, g). In E. coli, a D5N mutation in the conserved $\mathrm{N}$-terminal motif of $\mathrm{Fts} \mathrm{N}$ was shown to impair FtsA-FtsN interactions in vivo (Pichoff et al., 2015), but did not affect binding or co-localisation with FtsA-FtsZ filaments on supported lipid bilayers in vitro (Baranova et al., 2020). In contrast, and somewhat confusingly, mutation of the basic ${ }^{16} \mathrm{RRKK}^{19}$ stretch abrogated binding in vitro (Baranova et al., 2020; Busiek et al., 2012), yet was permissible in vivo under conditions for which the FtsA-FtsN interaction becomes essential (Pichoff et al., 2015). We therefore tested a set of EcFtsN ${ }^{1-32}$ truncations and mutations in our SPR and monolayer assays to determine the effect of those modifications on FtsA-FtsN interactions and on double filament formation (Supplementary Figure S2h, i). Mutation or deletion of any one of the three stretches 
bioRxiv preprint doi: https://doi.org/10.1101/2021.11.08.467742; this version posted November 8, 2021. The copyright holder for this preprint (which was not certified by peer review) is the author/funder, who has granted bioRxiv a license to display the preprint in perpetuity. It is made available under aCC-BY 4.0 International license.

FtsA-FtsN antiparallel double filaments

Nierhaus 2021

of basic amino acids in $\mathrm{EcFtsN}^{1-32}$ reduced binding affinity for FtsA and, consequently, its ability to promote FtsA double filament formation. EcFtsN ${ }^{1-32, ~ D 5 N}$ and EcFtsN ${ }^{1-33}$, scrambled (Supplementary Table T 4), which has been described previously but was shortened through removal of its tags in this study (Baranova et al., 2020), did not show reduced binding affinity. But, $\mathrm{EcFtsN}^{1-32, \mathrm{D} 5 \mathrm{~N}}$ and $\mathrm{EcFts} \mathrm{N}^{1-33}$, scrambled were unable to induce FtsA double filament formation. Hence, the D5N mutation in FtsN might be non-permissible in vivo under conditions for which the FtsA-FtsN interaction becomes essential because it fails to promote formation of FtsA double filaments. In other words, this result supports the idea that FtsA double filaments are important for the activation of cell division by FtsA and FtsN.

We then tested whether any of the FtsN suppressor (Bernard et al., 2007; Liu et al., 2015) or filament architecture and ZipA suppressor mutations (Schoenemann et al., 2018) in FtsA would impact FtsN-induced double filament formation of FtsA (Figure 1c). While the FtsN suppressor mutants $F t s A^{E 124 A}$ and $F t s A^{1143 L}$, similar to wildtype FtsA, formed "mini-rings" in the absence of EcFtsN ${ }^{1-32}$, they more readily formed double filaments than wildtype FtsA at three- $(7 \mu \mathrm{M})$ and six-fold $(13 \mu \mathrm{M})$ molar excess of EcFtsN ${ }^{1-32}$ (Figure $2 \mathrm{~g}$ ). The filament architecture and ZipA suppressor mutants Fts $A^{\mathrm{G} 50 \mathrm{E}}$ and $\mathrm{Fts} \mathrm{A}^{\mathrm{R} 286 \mathrm{~W}}$ (also known as $\mathrm{Fts}^{*}$ ) formed fewer "mini-rings" than wildtype FtsA in the absence of FtsN (Figure 2g). For FtsA ${ }^{\mathrm{G} 50 \mathrm{E}}$, "mini-rings" and short double filaments were observed. FtsA $\mathrm{A}^{\mathrm{R} 286 \mathrm{~W}}$ predominantly formed arcs, curved, short and single filaments. Similar to the Fts $\mathrm{A}^{\mathrm{E} 124 \mathrm{~A}}$ and $\mathrm{Fts} \mathrm{A}^{1143 \mathrm{~L}}$ proteins, $\mathrm{Fts} \mathrm{A}^{\mathrm{G} 50 \mathrm{E}}$ and $\mathrm{Fts} \mathrm{A}^{\mathrm{R} 286 \mathrm{~W}}$ formed many more double filaments than wildtype FtsA at three- $(7 \mu \mathrm{M})$ and six-fold $(13 \mu \mathrm{M})$ molar excess of EcFtsN ${ }^{1-32}$ (Figure $2 \mathrm{~g}$ ). Thus, both FtsN suppressor as well 
bioRxiv preprint doi: https://doi.org/10.1101/2021.11.08.467742; this version posted November 8, 2021. The copyright holder for this preprint (which was not certified by peer review) is the author/funder, who has granted bioRxiv a license to display the preprint in perpetuity. It is made available under aCC-BY 4.0 International license.

FtsA-FtsN antiparallel double filaments

Nierhaus 2021

as ZipA suppressor and FtsA filament architecture mutants appear to facilitate FtsNdependent FtsA double filament formation.

\section{VmFts $N^{1-29}$ binds VmFtsA ${ }^{1-396}$ in the IA-IC interdomain cleft}

To understand the FtsA-FtsN interaction at the molecular level, we co-crystallised VmFtsA ${ }^{1-396}$ with the V. maritimus cytoplasmic FtsN peptide, $\mathrm{VmFts}^{1-29}$. Although similar crystallisation conditions were used, the $\mathrm{VmFtsA}^{1-396}-\mathrm{VmFtsN}^{1-29}$ co-crystal structure (PDB 7Q6I) showed a larger unit cell than that obtained for the VmFtsA ${ }^{1-396}$ double filament structure [PDB 7Q6F, two FtsA monomers per asymmetric unit (ASU)], encompassing 16 FtsA monomers per ASU (Supplementary Table T 1). The 16 FtsA monomers are organised into four tetramers, each containing two antiparallel very short protofilaments, each comprised of two FtsA monomers (Figure 3a). One of the two FtsA monomers in a protofilament adopts a closed and the other one an open conformation (Supplementary Figure S3a). The positions of the IC domain in the closed (PDB 7Q6I chain A) and open (PDB 7Q6I chain B) conformation are similar but not identical to the IC domain position in the $\mathrm{VmFts} \mathrm{A}^{1-396}$ double filament (PDB 7Q6F) (Supplementary Figure S1b). Only in the IA-IC interdomain cleft of closed FtsA monomers could we find electron density for the $\mathrm{VmFtsN}^{1-29}$ peptide (Figure 3a, c; Supplementary Figure S3a). The IC domain in the open conformation is rotated downwards by $13.8^{\circ}$ compared to the closed conformation, as analysed by DynDom (Hayward and Lee, 2002) (Supplementary Figure S3a). This means the open conformation is likely incompatible with $\mathrm{VmFtsN}^{1-29}$ binding (Supplementary Figure S3a). The IC domains in the lateral interface of each tetramer are twisted against each other compared to the straight $V m F t s A^{1-396}$ double filament (Figure 3a). Several hydrogen bonding contacts are lost because of the bending when compared to the 
bioRxiv preprint doi: https://doi.org/10.1101/2021.11.08.467742; this version posted November 8,2021 . The copyright holder for this preprint (which was not certified by peer review) is the author/funder, who has granted bioRxiv a license to display the preprint in perpetuity. It is made available under aCC-BY 4.0 International license.

FtsA-FtsN antiparallel double filaments

Nierhaus 2021

straight filaments (Figure 3a, asterisks; Figure $3 b$ ). The $V m F t s A^{1-396}-V m F t s N^{1-29}$ tetramer is bent along the filament axis with an estimated radius of curvature of $16.3 \mathrm{~nm}$ (Figure 3b).

Due to the low resolution (3.6 $\mathrm{A}$ ) of the $\mathrm{VmFts}^{1-396}-\mathrm{VmFtsN}^{1-29}$ co-crystal structure (Supplementary Table T 1), we could not unambiguously interpret the electron density map representing about seven to eight amino acids of the $\mathrm{VmFtsN}^{1-29}$ peptide. We therefore confirmed the location of the $\mathrm{VmFtsN}^{1-29}$ binding site in $\mathrm{VmFts}^{1-396}$ by hydrogen deuterium exchange mass spectrometry (HDX-MS) (Figure 3d). At three-fold molar excess $(30 \mu \mathrm{M})$ of $\mathrm{VmFtsN}^{1-29}$ over $\mathrm{VmFts}^{1-396}$, only helix 2 located in the IC domain of FtsA showed significantly reduced deuterium incorporation (lower mass differential) compared to free $\mathrm{VmFts}^{1-396}$ (Figure 3d, top left). This agrees with VmFtsN ${ }^{1-29}$ binding across the IC domain as seen in the co-crystal structure (Figure 3c). At 10 -fold molar excess $(100 \mu \mathrm{M})$ of $\mathrm{VmFtsN}^{1-29}$, FtsA peptides in filament interfaces were also protected, again, indicating that binding of the cytoplasmic FtsN peptide to FtsA facilitates filament formation (Figure 3d).

The FtsA-FtsN interaction is reminiscent of that between PilM and PilN, two proteins involved in type IV pilus formation (Karuppiah and Derrick, 2011; McCallum et al., 2016). PilM, which also has a IC subdomain, is a structural homologue of FtsA, and PilN, similar to FtsN, is a bitopic membrane protein with a short, cytoplasmic tail comprising about 30 amino acids (Karuppiah and Derrick, 2011; McCallum et al., 2016). FtsN and PiIN both bind in the IA-IC interdomain cleft (assuming FtsA domain nomenclature for PilM), but use somewhat different binding modes (Supplementary 
bioRxiv preprint doi: https://doi.org/10.1101/2021.11.08.467742; this version posted November 8, 2021. The copyright holder for this preprint (which was not certified by peer review) is the author/funder, who has granted bioRxiv a license to display the preprint in perpetuity. It is made available under aCC-BY 4.0 International license.

FtsA-FtsN antiparallel double filaments

Nierhaus 2021

Figure S3b). PilN makes extensive contacts with the IA domain of PilM. FtsN binds further downward in the cleft, predominantly contacting the IC domain of FtsA.

As mentioned, the low resolution of the electron density for the $\mathrm{VmFts}^{1-29}$ peptide in the $V m F t s A^{1-396}-V_{m F t s}{ }^{1-29}$ co-crystal structure limited our ability to assign the peptide register and only peptide density associated with two FtsA monomers (PDB 7Q6I chains $A$ and $C$ ) was interpretable. Based on the geometry in vivo, where FtsA binds to the cell membrane through its C-terminal amphipathic helix, we reasoned that the $\mathrm{N}$-terminal half of $\mathrm{VmFtsN}^{1-29}$ is expected to interact with FtsA, as the globular domain of FtsA was reported to be several nanometres away from the inner membrane in E. coli (Szwedziak et al., 2014). The C-terminal half of the $\mathrm{VmFtsN}^{1-29}$ peptide would be confined to the proximity of the inner membrane, as it is linked to the transmembrane helix in the full-length FtsN protein (Supplementary Figure S2f). Amino acids M1-R8 of $\mathrm{VmFtsN}^{1-29}$ provided the best fit for the density with reasonable chemistry, i.e. several hydrogen bonds to FtsA and a hydrophobic pocket accommodating the central tyrosine (Y6) in the sequence stretch (Supplementary Figure S3e, left). This model also implies a central position of aspartate D5 within the FtsA-FtsN interaction site that could point to a mechanism by which the D5N mutation impairs double filament formation (Supplementary Figure S2h; Supplementary Figure S3e, left). In that case, FtsN ${ }^{\mathrm{DN}}$ would not be able to bridge FtsA's IA and IC domain. We further studied the $V m F t s A^{1-396}-V_{m F t s} N^{1-29}$ interaction by nuclear magnetic resonance (NMR) spectroscopy. We assigned the peptide backbone of Gly-Gly$\mathrm{VmFtsN}^{2-29}$, a $\mathrm{VmFtsN}^{1-29}$ construct in which two glycine residues replace the $\mathrm{N}$-terminal methionine (Supplementary Figure S3c). Next, we analysed peak broadening (reduction in peak intensity due to the slower tumbling rate of FtsA-bound 
bioRxiv preprint doi: https://doi.org/10.1101/2021.11.08.467742; this version posted November 8, 2021. The copyright holder for this preprint (which was not certified by peer review) is the author/funder, who has granted bioRxiv a license to display the preprint in perpetuity. It is made available under aCC-BY 4.0 International license.

FtsA-FtsN antiparallel double filaments

Nierhaus 2021

Gly-Gly-VmFtsN ${ }^{2-29}$ peptide) upon addition of equimolar amounts of $\mathrm{VmFts} \mathrm{A}^{1-396}$ (Supplementary Figure S3d). Intensity reduction was most prominent in the stretch of amino acids Y6-G10 (Supplementary Figure S3d), suggesting a slightly shifted binding motif compared to our density-based assignment (M1-R8) (Supplementary Figure S3e). We were not able to generate a good fit of these residues into the electron density map of the $\mathrm{VmFtsA} \mathrm{A}^{1-396}-\mathrm{VmFts} \mathrm{N}^{1-29}$ co-crystal structure. For technical reasons, the NMR experiments were carried out at $\mathrm{pH} 6.0$, whereas binding experiments were done at $\mathrm{pH} 7.7$ and crystallisation was achieved at $\mathrm{pH} 8.5$.

\section{FtsA double filaments prefer negative Gaussian curvature}

Based on the observation that $\mathrm{VmFts} \mathrm{A}^{1-396}-\mathrm{VmFtsN}^{1-29}$ double filaments were curved in the co-crystal structure (Figure 3b), we hypothesised that the intrinsic curvaturepreference of MreB double filaments might also be a feature of FtsA-FtsN double filaments (Hussain et al., 2018; Salje et al., 2011). The curvature preference of MreB filaments enables a curvature-sensing mechanism that allows them to robustly align in cells with the axis of highest principal curvature, which corresponds to the short axis of rod-shaped bacteria such as E. coli and B. subtilis (Hussain et al., 2018; Wong et al., 2019). The elongasome uses the aligned MreB filaments to guide glycan strand synthesis around the cell's circumference, producing radially inserted glycan strands that are believed to mechanically reinforce rod shape (Dion et al., 2019; Garner et al., 2011; Hussain et al., 2018).

To investigate the curvature preference of FtsA filaments, we bound EcFtsA-FtsN ${ }^{1-32}$ double filaments on the outside of liposomes by adding the proteins to preformed liposomes made of E. coli polar lipid extract. Liposomes vitrified on EM grids in the 
bioRxiv preprint doi: https://doi.org/10.1101/2021.11.08.467742; this version posted November 8, 2021. The copyright holder for this preprint (which was not certified by peer review) is the author/funder, who has granted bioRxiv a license to display the preprint in perpetuity. It is made available under aCC-BY 4.0 International license.

FtsA-FtsN antiparallel double filaments

Nierhaus 2021

absence of proteins are typically round or oval (Figure 4a, left). In contrast, liposomes coated with EcFtsA-FtsN $\mathrm{N}^{1-32}$ double filaments regularly showed membrane indentations with negative Gaussian curvature (Figure 4a, right). We encourage the reader to revisit previously published images of MreB double filaments bound to the outside of liposomes showing a remarkably similar binding mode (Salje et al., 2011; van den Ent et al., 2014). To better match the geometry inside an E. coli cell, we then encapsulated EcFtsA-FtsN ${ }^{1-32}$ double filaments in liposomes by co-dilution with CHAPS-solubilised E. coli total lipid extract (Szwedziak et al., 2014). Protein-filled liposomes were spherocylindrical (rod-shaped) or had spherocylindrical protrusions (Figure 4b). Spherocylinders were either $\sim 40 \mathrm{~nm}$ or $\sim 70 \mathrm{~nm}$ in diameter. Thicker spherocylinders contained tightly packed EcFtsA-FtsN ${ }^{1-32}$ double filaments that were aligned with the short axis in the cylindrical section (Figure $4 b, c)$. We again suggest the reader to compare with published images of MreB filaments inside liposomes showing similar filament arrangements (Hussain et al., 2018). EcFtsA-Fts $\mathrm{N}^{1-32}$ filaments were regularly absent in the hemispheres of thick spherocylinders (Figure $4 b, c)$. If filaments were present in the hemispheres, they showed random angular orientations (Figure 4c, bottom). Rarely, we obtained liposomes with only a few EcFtsA-FtsN ${ }^{1-32}$ double filaments inside (Figure 4d). Again, filaments were distributed randomly in spherical sections of the liposomes but aligned with the short axis of the liposomes in more cylindrical sections. We performed 2D averaging and image classification focussed on the membrane attachment sites of the FtsA filaments in thin and thick spherocylinders. Class averages clearly illustrated the different organisation of FtsA filaments in thin and thick spherocylinders (Figure 4e). In thin spherocylinders, FtsA was organised into bent single protofilaments, suggesting that only low concentrations of $\mathrm{FtsN}^{1-32}$ were encapsulated in the thin spherocylinders (Figure $4 \mathrm{e}$, 
bioRxiv preprint doi: https://doi.org/10.1101/2021.11.08.467742; this version posted November 8, 2021. The copyright holder for this preprint (which was not certified by peer review) is the author/funder, who has granted bioRxiv a license to display the preprint in perpetuity. It is made available under aCC-BY 4.0 International license.

FtsA-FtsN antiparallel double filaments

Nierhaus 2021

left). In thick spherocylinders however, FtsA formed bent double filaments, as apparent by superposition of the VmFtsA ${ }^{1-396}$ double filament crystal structure (PDB 7Q6F) onto the 2D class average (Figure $4 \mathrm{e}$, right).

\section{E. coli FtsA forms antiparallel double filaments in vivo}

To complement and validate our in vitro findings, we investigated double filament formation of FtsA in vivo using site-specific cysteine cross-linking in E. coli. For greater feasibility of targeting the native ftsA locus, which is located in the dense division and cell wall (dcw) gene cluster, and to increase throughput with a number of mutants needed, we used a derivative of replicon excision for enhanced genome engineering through programmed recombination 2 (REXER 2) (Wang et al., 2016) (Supplementary Figure S4a). We inserted a neoR marker downstream of $I p \times C$ for positive selection. For visualisation via Western blotting, we introduced a 3x HA-tag (comprising 40 amino acids including linkers) into the H7-S12 loop of FtsA (Bendezu et al., 2009; van den Ent and Löwe, 2000). Cysteine mutations for in vivo site-specific cross-linking were designed based on the $\mathrm{VmFts} \mathrm{A}^{1-396}$ double filament crystal structure (PDB 7Q6F) (Figure 5a). Mutant strains showed no growth defects and no elongated cells compared to the MG1655 parent strain (Supplementary Figure S4b-d).

This way we generated FtsA double cysteine mutant strains $f t s A^{3 x} H A, P 98 C, S 118 C$ and $f t s A^{3 \times H A}, E 199 C$, S252C, which probe the lateral FtsA $A_{i}-F t s A_{i^{*}-1}$ and the longitudinal Fts $A_{i^{-}}$ FtsA $_{i \pm 1}$ interface of the FtsA double filament, respectively (Figure 5b). E. coli cells were treated with bismaleimidoethane $(B M O E)$ in exponential phase $\left(O_{600}=0.2-0.4\right)$. BMOE enters living E. coli cells and rapidly cross-links closely spaced thiols such as cysteine side chains in vivo. FtsA species were visualised by SDS-PAGE and Western 
bioRxiv preprint doi: https://doi.org/10.1101/2021.11.08.467742; this version posted November 8, 2021. The copyright holder for this preprint (which was not certified by peer review) is the author/funder, who has granted bioRxiv a license to display the preprint in perpetuity. It is made available under aCC-BY 4.0 International license.

FtsA-FtsN antiparallel double filaments

Nierhaus 2021

blotting against the 3x HA-tag in FtsA (Figure 5c). We detected efficient formation of crosslinked FtsA dimers for both the fts $A^{3 \times H A, P 98 C,}$ S118C and fts $A^{3 \times H A, E 199 C,}$, $252 C$ double mutants, but only weak background signal spread across multiple species in single cysteine mutant controls. We also detected higher order polymers for the fts $A^{3 \times H A, E 199 C, ~ S 252 C}$ mutant since the open symmetry of the longitudinal filament contact allows for more than two FtsA monomers to be cross-linked, through chaining.

To probe the lateral association in vivo further, we generated the two, additional FtsA single cysteine mutant strains $f t s A^{3 \times H A, D 123 C}$ and $f t s A^{3 \times H A, Q 155 C}$, which probe the lateral Fts $\mathrm{A}_{i}-\mathrm{Fts} \mathrm{A}_{i^{*}}$ and $\mathrm{Fts} \mathrm{A}_{i}-\mathrm{Fts} \mathrm{A}_{i^{*}-1}$ interface of the FtsA double filament, respectively (Figure $5 \mathrm{~d}$ ). These single cysteine mutants may cross-link to their symmetry mates because of the local C2 symmetry in each of the two lateral filament interfaces. However, $C_{\beta}-C_{\beta}$ distances in the $V m F t s A$ double filament structure of $3.9 \AA$ for $\mathrm{fts} A^{3 \times} H A, D 123 C$ and $12.6 \AA$ for $f t s A^{3 \times} H A, Q 155 C$ indicated that cross-linking with BMOE with an expected cross-linking distance of $\sim 8 \AA$ might be inefficient, which prompted us to try thiol-directed cross-linkers of different lengths (Figure 5f). The fts $A^{3 x} H A, D 123 C$ mutant showed more efficient cross-linking of FtsA using dibromobimane ( $\mathrm{dBBr}$ ) than using BMOE (Figure 5e, left). In case of the fts $A^{3 x} H A, Q 155 C$ mutant, BMOE cross-linking did not lead to efficient formation of covalent FtsA dimers, whereas treatment with the longer maleimide cross-linkers 1,4-bismaleimidobutane (BMB) and bismaleimidohexane $(\mathrm{BMH})$ did (Figure 5e, right). Taken together, our data strongly suggest that FtsA forms protofilaments in cells and, that these protofilaments are further arranged into antiparallel double filaments as suggested by the $\mathrm{VmFts} \mathrm{A}^{1-396}$ crystal structure (PDB 7Q6F) . 
bioRxiv preprint doi: https://doi.org/10.1101/2021.11.08.467742; this version posted November 8,2021 . The copyright holder for this preprint (which was not certified by peer review) is the author/funder, who has granted bioRxiv a license to display the preprint in perpetuity. It is made available under aCC-BY 4.0 International license.

FtsA-FtsN antiparallel double filaments

Nierhaus 2021

\section{DISCUSSION}

Here, we found that FtsA forms antiparallel double filaments in E. coli and that in vitro the same filaments are induced by the binding of the cytoplasmic tail of FtsN. The only other polymerising actin-like protein known to form antiparallel and, therefore, apolar double filaments is the actin homologue of the elongasome, MreB, which serves as a "rudder" (Hussain et al., 2018; van den Ent et al., 2014; Wagstaff and Löwe, 2018). Given the shared preference for negative Gaussian curvature displayed by FtsA-FtsN and MreB double filaments reconstituted in and on liposomes (Hussain et al., 2018; Salje et al., 2011; van den Ent et al., 2014) (Figure 4), we propose that MreB and FtsA share the same curvature sensing mechanism. Hence, we put forward a model for curvature-guided cell constriction by FtsA-FtsN double filaments, which serve as a "rudder" to align the direction of the divisome's PG synthesis activity, more precisely glycan strand synthesis, with the cell's circumference (Figure 6a).

In our model, we discriminate three distinct phases in divisome assembly and maturation: unaligned FtsZ filaments at midcell, a fully assembled divisome aligned with the short axis of the cell, and a fully activated divisome synthesising septal PG and driving cell constriction (Figure 6a). However, the temporal order of individual recruitment and activation events during divisome maturation remains largely unknown and would benefit from in vivo single molecule imaging of FtsA. FtsZ filaments are positioned at midcell to determine the division plane but are unaligned in the absence of an alignment mechanism (Figure 6a, left). After recruitment of divisome proteins and Z-ring condensation (Squyres et al., 2021; Whitley et al., 2021), FtsN-induced FtsA double filaments will align themselves and the other divisome components with the short axis of the cell, possibly aided by FtsZ treadmilling, which 
bioRxiv preprint doi: https://doi.org/10.1101/2021.11.08.467742; this version posted November 8, 2021. The copyright holder for this preprint (which was not certified by peer review) is the author/funder, who has granted bioRxiv a license to display the preprint in perpetuity. It is made available under aCC-BY 4.0 International license.

FtsA-FtsN antiparallel double filaments

Nierhaus 2021

may provide a distribution mechanism that avoids FtsA filaments and divisome components to cluster in one spot (Bisson-Filho et al., 2017; McQuillen and Xiao, 2020; Yang et al., 2017) (Figure 6a, middle). We propose that curvature-sensing FtsA double filaments provide a solution to the FtsZ alignment problem noted previously (Du and Lutkenhaus, 2019). Consistently, the fraction of directionally treadmilling FtsZ filaments was reported to be decreased in a $\Delta f t s A$ strain of $B$. subtilis (Squyres et al., 2021). Together FtsA double filaments and treadmilling FtsZ filaments we suggest align and evenly distribute divisome components in the narrow division plane. Most importantly, this will restrict movement of FtsWI, the bipartite PG synthase of the divisome, in such a way that cell-constricting septal PG synthesis follows the cell's circumference (Figure 6a, right). In this context, FtsN might function as an activation switch of the divisome by coordinating activities of FtsA and FtsWI. Recently, a more direct interaction between FtsA and FtsW has been proposed (Park et al., 2021).

Based on bacterial and yeast two-hybrid assays, it has been suggested that FtsN promotes divisome maturation through depolymerisation of FtsA, which would free FtsA's IC domain and thereby allow recruitment of downstream divisome components (Pichoff et al., 2012; Pichoff et al., 2015, 2018). In contradiction to that we found that the short cytoplasmic tail of FtsN promotes FtsA polymerisation, or more precisely FtsA double filament formation (Figure 2c, $d$ and $\mathrm{g}$ ). Our work adds to previous evidence illustrating that FtsA can form different polymers (Krupka et al., 2017; Schoenemann et al., 2018; Szwedziak et al., 2012). Using FRET probes attached to FtsA, a complementary fluorescence microscopy study found FtsA* to be less polymeric than wildtype FtsA on supported lipid bilayers (Radler et al., manuscript in preparation). Addition of cytoplasmic FtsN peptide however induced FtsA* 
bioRxiv preprint doi: https://doi.org/10.1101/2021.11.08.467742; this version posted November 8, 2021. The copyright holder for this preprint (which was not certified by peer review) is the author/funder, who has granted bioRxiv a license to display the preprint in perpetuity. It is made available under aCC-BY 4.0 International license.

FtsA-FtsN antiparallel double filaments

Nierhaus 2021

polymerisation to levels comparable to wildtype FtsA, again questioning the prevalent model that FtsN depolymerises FtsA. Further, our data clearly demonstrate that the FtsA double filament is compatible with FtsN binding, as could be the case for other downstream divisome components. Double filament formation will also position FtsA's IC domain close to the inner membrane (Supplementary Figure S1c), which could facilitate recruitment of downstream divisome components that possibly bind to FtsA's IC domain such as FtsQ (Baranova et al., 2020).

Taken together with recent reports establishing FtsWI (Taguchi et al., 2019) and RodA-PBP2 (Cho et al., 2016; Sjodt et al., 2020) as bipartite PG synthases, our data on the similarities between FtsA and MreB double filaments strengthen the previously proposed evolutionary relationship between the divisome and elongasome (Szwedziak and Löwe, 2013) (Figure 6b). In Chlamydia, one of the few bacteria that lack FtsZ, MreB was implied to organise cell division (Jacquier et al., 2015; Ranjit et al., 2020), yet another indication that divisome and elongasome share at least some basic principles of function.

In this context it is also interesting to speculate which of FtsZ's many functions in cell division "converted" the presumably ancestral elongasome into the divisome. Our model suggests that FtsZ is the long-range organiser of the division site which ensures that septal PG synthases are functioning in a single division plane, only, and are evenly distributed around the cell's circumference. FtsA on the other hand aligns these PG synthases with the orientation of the division ring, making sure septal PG glycan synthesis by the divisome goes around the ring's circumference. It will require further studies before we truly understand, or can reconstitute FtsZ-based cell division but our 
bioRxiv preprint doi: https://doi.org/10.1101/2021.11.08.467742; this version posted November 8, 2021. The copyright holder for this preprint (which was not certified by peer review) is the author/funder, who has granted bioRxiv a license to display the preprint in perpetuity. It is made available under aCC-BY 4.0 International license.

FtsA-FtsN antiparallel double filaments

Nierhaus 2021

present study highlights the central role FtsA polymerisation might play in this process

and, further, illustrates important similarities between elongasome and divisome mechanisms. 
bioRxiv preprint doi: https://doi.org/10.1101/2021.11.08.467742; this version posted November 8,2021 . The copyright holder for this preprint (which was not certified by peer review) is the author/funder, who has granted bioRxiv a license to display the preprint in perpetuity. It is made available under aCC-BY 4.0 International license.

FtsA-FtsN antiparallel double filaments

Nierhaus 2021

\section{METHODS}

\section{Expression plasmids}

Expression plasmids (Supplementary Table T 2) were cloned by isothermal assembly using NEBuilder HiFi DNA Assembly Mix (NEB). Plasmids were transformed into E. coli MAX Efficiency DH5a (ThermoFisher) or C41(DE3) cells (Lucigen or Sigma) for plasmid propagation and protein expression, respectively.

\section{Protein expression and purification}

The amino acid sequences of all proteins used in this study are listed in Supplementary Table $\mathrm{T}$ 3. If applicable, removable tags that were cleaved during purification are indicated. All purification steps were carried out on ice or in a cold room at $4-6^{\circ} \mathrm{C}$ unless stated otherwise. Buffers were prepared in Millipore water (MPW), $\mathrm{pH}$-adjusted at room temperature and filtered through a $0.2 \mu \mathrm{m}$ PES filter.

\section{SUMO protease (GST-SENP1)}

GST-SENP1 (pTN_AN_902) was expressed in C41(DE3) cells. Cells were grown in 2xTY medium, supplemented with $100 \mu \mathrm{g} / \mathrm{ml}$ ampicillin, at $37^{\circ} \mathrm{C}$. Expression was induced at $\mathrm{OD}_{600}=0.6-0.8$ by adding $0.5 \mathrm{mM}$ IPTG. Cells were grown over night at $18^{\circ} \mathrm{C}$ and harvested by centrifugation. Cells were lysed in buffer SA (50 mM Tris/ $\mathrm{HCl}$, $150 \mathrm{mM} \mathrm{NaCl}, 2$ mM TCEP, 1 mM EDTA, $5 \%$ glycerol, pH 8.5), supplemented with DNase, RNase and cOmplete EDTA-free Protease Inhibitor Cocktail (Roche), using a cell disruptor at $25 \mathrm{kpsi}$ (Constant Systems). The lysate was cleared by ultracentrifugation at $100,000 \times \mathrm{g}$ for $30 \mathrm{~min}$ at $4^{\circ} \mathrm{C}$. The supernatant was added to pre-washed Glutathione Sepharose 4B beads (Cytiva) and incubated for $2 \mathrm{~h}$ at $4{ }^{\circ} \mathrm{C}$, with gentle stirring. The sample was passed through an Econo gravity flow column 
bioRxiv preprint doi: https://doi.org/10.1101/2021.11.08.467742; this version posted November 8,2021 . The copyright holder for this preprint (which was not certified by peer review) is the author/funder, who has granted bioRxiv a license to display the preprint in perpetuity. It is made available under aCC-BY 4.0 International license.

FtsA-FtsN antiparallel double filaments

Nierhaus 2021

(Bio-Rad) and washed $5 x$ with $50 \mathrm{ml}$ buffer SA, followed by $2 x 50 \mathrm{ml}$ buffer SB (buffer SA with $500 \mathrm{mM} \mathrm{NaCl}$ ) and 2x $50 \mathrm{ml}$ buffer SA. The protein was eluted in 5x $5 \mathrm{ml}$ buffer SA supplemented with $10 \mathrm{mM}$ reduced glutathione. Peak fractions were pooled and concentrated with a Vivaspin 20 concentrator (30 kDa MWCO, Sartorius). The protein was further purified by size exclusion chromatography on a HiLoad 26/600 Superdex 200 pg column (Cytiva), equilibrated in buffer SEC-S (50 mM Tris/HCl, 50 $\mathrm{mM} \mathrm{NaCl}, 5 \mathrm{mM}$ TCEP, $1 \mathrm{mM}$ EDTA, $1 \mathrm{mM} \mathrm{NaN}_{3}, 5 \%$ glycerol, pH 8.0). Peak fractions were analysed by SDS-PAGE, pooled and concentrated to $\sim 15-20 \mathrm{mg} / \mathrm{ml}$ using Vivaspin 20 concentrators (30 kDa MWCO, Sartorius). Small aliquots were flash-frozen in liquid nitrogen and stored at $-80^{\circ} \mathrm{C}$.

\section{TEV protease $\left(6 \mathrm{H}-\mathrm{Po} / \mathrm{G}^{*}\right)$}

6H-PolG* (pTN_AN_901) was expressed in C41(DE3) cells. Cells were grown in 2xTY medium, supplemented with $30 \mu \mathrm{g} / \mathrm{ml}$ kanamycin, at $37^{\circ} \mathrm{C}$. Expression was induced at $\mathrm{OD}_{600}=0.6-0.8$ by adding $1 \mathrm{mM}$ IPTG. Cells were grown over night at $19^{\circ} \mathrm{C}$ and harvested by centrifugation. Cells were lysed in TEV lysis buffer $(20 \mathrm{mM}$ Tris/HCl, 500 $\mathrm{mM} \mathrm{NaCl}, 1 \mathrm{mM}$ TCEP, $1 \mathrm{mM} \mathrm{NaN}_{3}, \mathrm{pH} 8.0$ ), supplemented with DNase and RNase using a cell disruptor at $25 \mathrm{kpsi}$ (Constant Systems). The lysate was cleared by ultracentrifugation at $100,000 \mathrm{x}$ for $30 \mathrm{~min}$ at $4^{\circ} \mathrm{C} .20 \mathrm{mM}$ imidazole was added to the supernatant before loading onto a HisTrap FF column (Cytiva). The column was washed with TEV Iysis buffer supplemented with $20 \mathrm{mM}$ imidazole. The protease was eluted in TEV lysis buffer with increasing amounts of imidazole (50/100/200/500 mM steps). Peak fractions were pooled and concentrated with Vivaspin 20 concentrators (10 kDa MWCO, Sartorius). Concentrated protein was further purified by size exclusion chromatography on a HiLoad 16/600 Superdex 75 pg column (Cytiva), 
bioRxiv preprint doi: https://doi.org/10.1101/2021.11.08.467742; this version posted November 8, 2021. The copyright holder for this preprint (which was not certified by peer review) is the author/funder, who has granted bioRxiv a license to display the preprint in perpetuity. It is made available under aCC-BY 4.0 International license.

FtsA-FtsN antiparallel double filaments

Nierhaus 2021

equilibrated in TEV lysis buffer. Peak fractions were analysed by SDS-PAGE, pooled and concentrated to $30 \mathrm{mg} / \mathrm{ml}$ using Vivaspin 20 concentrators (10 kDa MWCO, Sartorius). Small aliquots were flash-frozen in liquid nitrogen and stored at $-80^{\circ} \mathrm{C}$.

\section{Full-length FtsAs}

C-terminal intein-CBD-12H fusions of EcFtsA (pTN_AN_001), EcFtsA ${ }^{\text {M96E, R153D }}$ $\left(p T N \_A N \_059\right), E c F t s A^{E 124 A}\left(p T N \_A N \_003\right), E c F t s A^{I 143 L}\left(p T N \_A N \_004\right), E c F t s A^{G 50 E}$ $\left(p T N \_A N \_024\right), \quad E c F t s A^{R 286 W} / E c F t s A^{*}$ (pTN_AN_005) or VmFtsA (pTN_AN_057) were expressed in C41(DE3) cells. Cells were grown in 2xTY, supplemented with $100 \mu \mathrm{g} / \mathrm{ml}$ ampicillin, at $37^{\circ} \mathrm{C}$. Expression was induced at $\mathrm{OD}_{600}=0.8-1.0$ by adding $0.5 \mathrm{mM}$ IPTG. Cells were grown over night at $18^{\circ} \mathrm{C}$ and harvested by centrifugation. Cells were lysed in buffer LB2 (50 mM Tris/HCl, $500 \mathrm{mM} \mathrm{NaCl,} 5 \mathrm{mM}$ TCEP, $10 \mathrm{mM}$ $\mathrm{MgCl}$ 2, $1 \mathrm{mM} \mathrm{NaN}_{3}, \mathrm{pH}$ 8.0), supplemented with DNase, RNase and cOmplete EDTA-free Protease Inhibitor Cocktail (Roche), using a cell disruptor at $25 \mathrm{kpsi}$ (Constant Systems). The lysate was cleared by ultracentrifugation at $100,000 \times \mathrm{g}$ for $30 \mathrm{~min}$ at $4^{\circ} \mathrm{C} .50 \mathrm{mM}$ imidazole was added to the supernatant before loading onto a HisTrap HP column (Cytiva). After loading, the column was washed with buffer SEC2 (50 mM CHES/KOH, 500 mM KCl, 5 mM TCEP, 10 mM MgCl2, 5 \% glycerol, 1 mM $\mathrm{NaN}_{3}, \mathrm{pH}$ 9.0) supplemented with $100 \mathrm{mM}$ imidazole. The protein was eluted in buffer SEC2 with increasing amounts of imidazole (200/300/500 mM steps). Most of the protein eluted in $200 \mathrm{mM}$ imidazole. Peak fractions were pooled and loaded onto chitin resin (NEB) packed in a XK 50/20 column (Cytiva). The column was thoroughly washed with buffer CHIT2 (50 mM CHES/KOH, 500 mM KCl, 5 mM TCEP, 10 mM $\mathrm{MgCl} 2,5 \%$ glycerol, $1 \mathrm{mM} \mathrm{EGTA}, 1 \mathrm{mM} \mathrm{NaN}_{3}, \mathrm{pH}$ 9.0), followed by 2 column volumes (CV) of buffer CHIT2 + 50 mM $\beta$-mercaptoethanol. Afterwards, the flow was stopped, 
bioRxiv preprint doi: https://doi.org/10.1101/2021.11.08.467742; this version posted November 8, 2021. The copyright holder for this preprint (which was not certified by peer review) is the author/funder, who has granted bioRxiv a license to display the preprint in perpetuity. It is made available under aCC-BY 4.0 International license.

FtsA-FtsN antiparallel double filaments

Nierhaus 2021

and the column incubated over night at $4^{\circ} \mathrm{C}$, allowing for intein cleavage. Cleaved Fts $\mathrm{A}$ was eluted with $2 \mathrm{CV}$ of buffer CHIT2 $+50 \mathrm{mM} \beta$-mercaptoethanol, followed by $2 \mathrm{CV}$ of buffer CHIT2. The protein was concentrated with Vivaspin 20 concentrators $(30 \mathrm{kDa}$ MWCO, Sartorius). Concentrated protein was further purified by size exclusion chromatography on a HiLoad 16/600 Superdex 200 pg column (Cytiva), equilibrated in buffer SEC2. Peak fractions were analysed by SDS-PAGE, pooled and concentrated to $7-8 \mathrm{mg} / \mathrm{ml}$ using Vivaspin 20 concentrators (30 kDa MWCO, Sartorius). Small aliquots were flash-frozen in liquid nitrogen and stored at $-80^{\circ} \mathrm{C}$. Protein mass for each batch was verified by ESI-TOF mass spectrometry on a Micromass LCT mass spectrometer (Waters).

\section{C-terminally truncated FtsAs}

N-terminal $6 \mathrm{H}-\mathrm{SUMO}$ fusions of EcFtsA ${ }^{1-405}$ (pTN_AN_022), XpFtsA ${ }^{1-396}$ (pTN_AN_050) or VmFtsA ${ }^{1-396}$ (pTN_AN_052) were expressed in C41(DE3) cells. Cells were grown in $2 x T Y$, supplemented with $30 \mu \mathrm{g} / \mathrm{ml}$ kanamycin, at $37^{\circ} \mathrm{C}$. Expression was induced at $\mathrm{OD}_{600}=0.8-1.0$ by adding $0.5 \mathrm{mM} \mathrm{IPTG}$. For XpFts $\mathrm{A}_{\Delta \mathrm{c}}$, cells were harvested by centrifugation $5 \mathrm{~h}$ later. Cells expressing $6 \mathrm{H}$-SUMOEcFtsA ${ }^{1-405}$ or $6 \mathrm{H}-\mathrm{SUMO}-\mathrm{VmFts} \mathrm{A}^{1-396}$ were grown over night at $25^{\circ} \mathrm{C}$ and harvested the next day by centrifugation. Cells were lysed in buffer LB2 (50 mM Tris/HCl, 500 $\mathrm{mM} \mathrm{NaCl}, 5 \mathrm{mM}$ TCEP, $10 \mathrm{mM} \mathrm{MgCl}_{2}, 1 \mathrm{mM} \mathrm{NaN}_{3}, \mathrm{pH}$ 8.0), supplemented with DNase, RNase and cOmplete EDTA-free Protease Inhibitor Cocktail (Roche), using a cell disruptor at $25 \mathrm{kpsi}$ (Constant Systems). The lysate was cleared by ultracentrifugation at $100,000 \times \mathrm{g}$ for $30 \mathrm{~min}$ at $4^{\circ} \mathrm{C} .20 \mathrm{mM}$ imidazole was added to the supernatant before loading onto a HisTrap HP column (Cytiva). After loading, the column was washed with buffer SEC2 (50 mM CHES/KOH, $500 \mathrm{mM} \mathrm{KCl,} 5 \mathrm{mM}$ TCEP, $10 \mathrm{mM}$ 
bioRxiv preprint doi: https://doi.org/10.1101/2021.11.08.467742; this version posted November 8,2021 . The copyright holder for this preprint (which was not certified by peer review) is the author/funder, who has granted bioRxiv a license to display the preprint in perpetuity. It is made available under aCC-BY 4.0 International license.

FtsA-FtsN antiparallel double filaments Nierhaus 2021

$\mathrm{MgCl}_{2}, 5 \%$ glycerol, $1 \mathrm{mM} \mathrm{NaN}$, $\mathrm{pH}$ 9.0) supplemented with $20 \mathrm{mM}$ imidazole. The protein was eluted in buffer SEC2 with increasing amounts of imidazole $(100 / 300 / 500 \mathrm{mM}$ steps). Most of the protein eluted in $100 \mathrm{mM}$ imidazole. Peak fractions were pooled and mixed with pre-washed Glutathione Sepharose 4B beads (Cytiva) and purified GST-SENP1 (final concentration $\sim 0.01 \mathrm{mg} / \mathrm{ml}$ ). The sample was incubated over night at $4^{\circ} \mathrm{C}$, with gentle stirring. The next day, the sample was passed through an Econo gravity flow column (Bio-Rad). The flow-through was concentrated using Vivaspin 20 concentrators (30 kDa MWCO, Sartorius). Concentrated protein was further purified by size exclusion chromatography on a HiLoad 26/600 Superdex 200 pg column (Cytiva), equilibrated in buffer SEC2 in case of EcFtsA ${ }^{1-405}$ or crystallisation buffer $\left(20 \mathrm{mM} \mathrm{CHES} / \mathrm{KOH}, 100 \mathrm{mM} \mathrm{KCl}, 5 \mathrm{mM}\right.$ TCEP, $5 \mathrm{mM} \mathrm{MgCl}_{2}, 5 \%$ glycerol, $1 \mathrm{mM} \mathrm{NaN}_{3}, \mathrm{pH}$ 9.0) in case of $\mathrm{XpFts}^{1-396}$ and $\mathrm{VmFts}^{1-396}$. Peak fractions were analysed by SDS-PAGE, pooled and concentrated to $12-19 \mathrm{mg} / \mathrm{ml}$ using Vivaspin 20 concentrators (30 kDa MWCO, Sartorius). Small aliquots were flash-frozen in liquid nitrogen and stored at $-80^{\circ} \mathrm{C}$. Protein mass for each batch was verified by ESI-TOF mass spectrometry on a Micromass LCT mass spectrometer (Waters).

Isotope-labelled VmFtsN ${ }^{1-29}-E N L Y F Q$ and Gly-Gly-VmFtsN $N^{2-29}$

Isotope-labelled proteins were overexpressed in C41(DE3) cells in M9 media (6 g/L

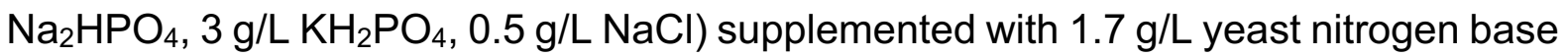
without $\mathrm{NH}_{4} \mathrm{Cl}$ and amino acids (Sigma Y1251). $1 \mathrm{~g} / \mathrm{L}{ }^{15} \mathrm{NH}_{4} \mathrm{Cl}$ and $4 \mathrm{~g} / \mathrm{L}{ }^{13} \mathrm{C}$-glucose were supplemented for ${ }^{15} \mathrm{~N}$ and ${ }^{13} \mathrm{C}$ labelling, respectively. $V m F t s N^{1-29}-E N L Y F Q$ (pTN_AN_069) and Gly-Gly-VmFtsN ${ }^{2-29}$ (pTN_AN_071) were expressed in C41(DE3) cells grown in the presence of $30 \mu \mathrm{g} / \mathrm{ml}$ ampicillin at $37^{\circ} \mathrm{C}$. Expression was induced at 
bioRxiv preprint doi: https://doi.org/10.1101/2021.11.08.467742; this version posted November 8, 2021. The copyright holder for this preprint (which was not certified by peer review) is the author/funder, who has granted bioRxiv a license to display the preprint in perpetuity. It is made available under aCC-BY 4.0 International license.

FtsA-FtsN antiparallel double filaments

Nierhaus 2021

$\mathrm{OD}_{600}=0.6-0.8$ by adding $0.5 \mathrm{mM}$ IPTG. Cells were grown over night at $25^{\circ} \mathrm{C}$ and harvested by centrifugation. Cells were lysed in buffer LB5 (50 mM HEPES/KOH, 250 $\mathrm{mM} \mathrm{KCl}, 1 \mathrm{mM}$ TCEP, $\mathrm{pH}$ 7.7), supplemented with DNase, RNase and cOmplete EDTA-free Protease Inhibitor Cocktail (Roche), using a cell disruptor at $25 \mathrm{kpsi}$ (Constant Systems). The lysate was cleared by ultracentrifugation at 100,000x g for $30 \mathrm{~min}$ at $4^{\circ} \mathrm{C} .20 \mathrm{mM}$ imidazole was added to the supernatant before loading onto a HisTrap HP column (Cytiva). The column was washed with buffer LB5 supplemented with $20 \mathrm{mM}$ or $50 \mathrm{mM}$ imidazole for $V m F t s N^{1-29}-E N L Y F Q$ and Gly-Gly-VmFtsN ${ }^{2-29}$, respectively. Proteins were eluted in buffer LB5 with increasing amounts of imidazole (100/200/300/500 mM steps). Peak fractions were pooled and mixed with TEV protease, $6 \mathrm{H}-\mathrm{PolG}^{*}$, (final concentration $0.01-0.02 \mathrm{mg} / \mathrm{ml}$ ). The sample was incubated over night at $4^{\circ} \mathrm{C}$, with gentle stirring. The next day, samples were diluted with buffer LB5 to a final imidazole concentration of $\sim 50 \mathrm{mM}$ and loaded onto a HisTrap HP column equilibrated in buffer LB5 supplemented with $50 \mathrm{mM}$ imidazole. The column was washed with buffer LB5 supplemented with $50 \mathrm{mM}$ imidazole. Flow-through and wash fractions were pooled and concentrated using Vivaspin 15R concentrators (2 kDa MWCO HY, Sartorius).

For Gly-Gly-VmFtsN ${ }^{2-29}$ only, an additional cation exchange purification step was performed. The sample was diluted in buffer SA2 (50 mM HEPES/KOH, $50 \mathrm{mM} \mathrm{KCl,}$ $1 \mathrm{mM}$ TCEP, $\mathrm{pH}$ 7.7) to a final salt concentration of $\leq 100 \mathrm{mM}$ and loaded on a HiTrap SP HP column (Cytiva). The sample was eluted with a linear gradient of buffer SB2 (50 mM HEPES/KOH, $1000 \mathrm{mM} \mathrm{KCl,} 1 \mathrm{mM}$ TCEP, pH 7.7). Peak fractions were pooled and concentrated.

Concentrated VmFtsN ${ }^{1-29}$-ENLYFQ or Gly-Gly-VmFtsN ${ }^{2-29}$ was further purified by size exclusion chromatography on a Superdex Peptide 10/300 GL column (Cytiva), 
bioRxiv preprint doi: https://doi.org/10.1101/2021.11.08.467742; this version posted November 8,2021 . The copyright holder for this preprint (which was not certified by peer review) is the author/funder, who has granted bioRxiv a license to display the preprint in perpetuity. It is made available under aCC-BY 4.0 International license.

FtsA-FtsN antiparallel double filaments

Nierhaus 2021

equilibrated in NMR buffer (50 mM MES/KOH, 50 mM KCl, 1 mM TCEP, pH 6.0). Peak fractions were analysed by SDS-PAGE, pooled and concentrated to $2-3 \mathrm{mg} / \mathrm{ml}$ using Vivaspin 15R concentrators (2 kDa MWCO HY, Sartorius). Small aliquots were flash-frozen in liquid nitrogen and stored at $-80^{\circ} \mathrm{C}$. Protein mass for each batch was verified by ESI-TOF mass spectrometry on a Micromass LCT mass spectrometer (Waters).

\section{FtsN peptides}

All FtsN peptides were chemically synthesised by Generon/Neobiotech. Purity ( $\geq 95 \%$ in HPLC) and molecular mass were verified by the company. Lyophilised peptides were resuspended in binding buffer (50 mM HEPES/KOH, $100 \mathrm{mM} \mathrm{KAc,} 5 \mathrm{mM} \mathrm{MgAc} 2$, $\mathrm{pH}$ 7.7). Stock concentrations were determined using an ND-1000 spectrophotometer (NanoDrop Technologies) or, if the peptide did not contain any tyrosines or tryptophans, a Direct Detect Infrared Spectrometer (Merck Millipore). Concentrations of resuspended peptides were in the range of 20-70 mM. Peptide sequences are given in Supplementary Table T 4.

\section{Crystal structure determination}

Crystallisation conditions were screened using our in-house high-throughput crystallisation facility (Gorrec and Löwe, 2018). EcFtsA ${ }^{1-405}$ at $7 \mathrm{mg} / \mathrm{ml}, \mathrm{XpFts}^{1-396}$ at $7 \mathrm{mg} / \mathrm{ml}$ or $\mathrm{VmFts} \mathrm{A}^{1-396}$ at $5 \mathrm{mg} / \mathrm{ml}$ was mixed with $2 \mathrm{mM} \mathrm{ATP}$. For co-crystallisation, VmFtsA ${ }^{1-396}$ at $3 \mathrm{mg} / \mathrm{ml}$ was mixed with $2 \mathrm{mM} \mathrm{ATP}$ and $0.353 \mathrm{mM} \mathrm{VmFtsN}^{1-29}$ (5-fold molar excess). For EcFtsA $\mathrm{A}^{1-405}$ and $\mathrm{XpFtsA}^{1-396}, 100 \mathrm{nl}$ protein solution and $100 \mathrm{nl}$ of the crystallisation solutions were mixed in MRC sitting drop crystallisation plates for vapour diffusion. $500 \mathrm{nl}$ protein solution and $500 \mathrm{nl}$ of crystallisation solutions were 
bioRxiv preprint doi: https://doi.org/10.1101/2021.11.08.467742; this version posted November 8, 2021. The copyright holder for this preprint (which was not certified by peer review) is the author/funder, who has granted bioRxiv a license to display the preprint in perpetuity. It is made available under aCC-BY 4.0 International license.

FtsA-FtsN antiparallel double filaments

Nierhaus 2021

used to obtain optimised co-crystals of $\mathrm{VmFts} \mathrm{A}^{1-396}$ with $\mathrm{VmFts} \mathrm{N}^{1-29}$. Optimisation for VmFtsA ${ }^{1-396}$ followed the idea of an "anticipated optimisation approach" (Gorrec, 2019). $250 \mathrm{nl}$ of protein solution were mixed with $200 \mathrm{nl}$ of initial crystallisation solution $(31.55 \%$ v/v PEG 400, $0.21 \mathrm{M} \mathrm{MgCl} 2,0.1 \mathrm{M}$ Tris/HCl pH 8.5) and $50 \mathrm{nl}$ of follow-up crystallisation solution (10 \% v/v 2-propanol, 0.2 $\mathrm{M} \mathrm{CaAc}_{2}, 0.1 \mathrm{M} \mathrm{MES/NaOH} \mathrm{pH} \mathrm{6.0).}$ When completed, drops were pipetted up and down 5 times by the Mosquito robot (TTP Labtech) to minimise diffusion effects. Plates were incubated at $21^{\circ} \mathrm{C} .1-2 \mu \mathrm{l}$ of cryoprotectant solution were added to crystals shortly before mounting. Single crystals were mounted in CryoLoops (Hampton Research) and flash-frozen in liquid nitrogen. VmFtsA ${ }^{1-396}-\mathrm{FtsN}^{1-29}$ co-crystals (PDB 7Q6I) were soaked in cryoprotectant solution for $1 \mathrm{~h}$ prior to mounting. Optimised conditions yielding crystals and cryoprotectant solutions are listed in Supplementary Table T 1. Diffraction data were collected on single crystals at Diamond Light Source (DLS), Harwell, UK, at $100 \mathrm{~K}$, as indicated in Supplementary Table T 1. XDS (Kabsch, 2010), POINTLESS and SCALA (Evans, 2006) or DIALS (Winter et al., 2018) were used to process diffraction images. Initial phases were obtained by molecular replacement using PHASER (McCoy et al., 2007). Search models used for molecular replacement are indicated in Supplementary Table T 1. Models were rebuilt manually using MAIN (Turk, 2013) and COOT (Emsley et al., 2010) and refined using REFMAC (Murshudov et al., 1997) and PHENIX (Afonine et al., 2018). Models were validated using PROCHECK (Laskowski et al., 1993) and MOLPROBITY (Williams et al., 2018). Final statistics are summarised in Supplementary Table T 1, and the structure factors as well as atomic coordinates have been deposited in the Protein Data Bank (PDB) with accession codes 7Q6D, 7Q6G, 7Q6F and 7Q6I. Note that $\mathrm{VmFtsN}^{1-29}$ (chains $\mathrm{X}$ and $\mathrm{Y}$ ) density was modelled as VmFtsN ${ }^{1-8}$ for refinement but deposited as polyAla. 
bioRxiv preprint doi: https://doi.org/10.1101/2021.11.08.467742; this version posted November 8,2021 . The copyright holder for this preprint (which was not certified by peer review) is the author/funder, who has granted bioRxiv a license to display the preprint in perpetuity. It is made available under aCC-BY 4.0 International license.

FtsA-FtsN antiparallel double filaments

Nierhaus 2021

\section{Surface plasmon resonance (SPR)}

SPR was performed using a Biacore T200 using CM5-sensor chips (Cytiva). Both reference control and analyte channels were equilibrated in binding buffer $(50 \mathrm{mM}$ HEPES/KOH, 100 mM KAc, 5 mM MgAc 2 , pH 7.7). EcFtsA, EcFtsA ${ }^{1-405}$ or VmFtsA ${ }^{1-396}$ was immobilised onto the chip surface via amide coupling using the supplied kit (Cytiva) to reach a RU value of between 2000 and $7800 \mathrm{RU}$ for separate experiments. SPR runs were performed with analytes injected for $120 \mathrm{~s}$ followed by a $300 \mathrm{~s}$ dissociation in a 1:2 dilution series with initial concentrations of: $10 \mu \mathrm{M}$ for peptide EcFts $\mathrm{N}^{1-32}$ (Figure 2a); $60 \mu \mathrm{M}$ for $\mathrm{VmFtsN}^{1-29}$ (Supplementary Figure S2a); $20 \mu \mathrm{M}$ for peptides EcFtsN ${ }^{1-12}, \quad E c F t s N^{1-22}, \quad E c F t s N^{11-32}, \quad E c F t s N^{4-26}, \quad E c F t s N^{1-32}, \quad E c F t s N^{1-32, ~ D 5 N}$, EcFtsN $^{1-32, \Delta R K 1}, \quad$ EcFtsN $^{1-32, \Delta R K 2}, \quad$ EcFtsN $^{1-32, \Delta R K 3}, \quad \operatorname{EcFtsN}^{1-32, \Delta R K 2,3}$ and EcFtsN ${ }^{1-33, \text { scrambled }}$ (Supplementary Figure S2i). After reference and buffer signal correction, sensogram data were fitted using Prism 8.0 (GraphPad Software Inc). The equilibrium response $\left(R_{e q}\right)$ data were fitted to a single-site interaction model to determine $K_{d}$ :

$$
R_{e q}=\left(\frac{C R_{\max }}{C+K_{d}}\right)+B
$$

where $C$ is the analyte concentration and $R_{\max }$ is the maximum response at saturation and $B$ is the background resonance. Binding constants are given as mean.

\section{Fluorescence polarisation (FP)}

Peptides $\mathrm{EcFts}^{1-32}-\mathrm{C}$ and $\mathrm{VmFtsN}^{1-29}-\mathrm{C}$ were labelled with maleimide-Atto 495 (Merck Life Science UK). EcFtsA $\mathrm{A}^{1-405}$ and $\mathrm{VmFtsA}^{1-396}$ were buffer exchanged into

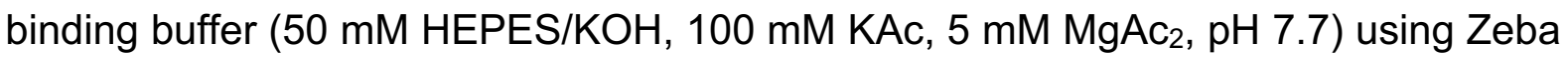
Spin Desalting Columns $(0.5 \mathrm{ml}, 7 \mathrm{kDa}$ MWCO, ThermoFisher $)$ prior to FP experiments. $20 \mathrm{nM}$ labelled peptide was mixed 1:1 with a 1:2 dilution series of protein 
bioRxiv preprint doi: https://doi.org/10.1101/2021.11.08.467742; this version posted November 8,2021 . The copyright holder for this preprint (which was not certified by peer review) is the author/funder, who has granted bioRxiv a license to display the preprint in perpetuity. It is made available under aCC-BY 4.0 International license.

FtsA-FtsN antiparallel double filaments

Nierhaus 2021

with initial concentrations of $40 \mu \mathrm{M}$ for $\mathrm{EcFts}^{1-405}$ or $120 \mu \mathrm{M}$ for $\mathrm{VmFts} \mathrm{A}^{1-396}$ in binding buffer supplemented with Tween-20 (50 mM HEPES/KOH, 100 mM KAc, 5 mM MgAc 2 , $\mathrm{pH} 7.7,0.05 \% \mathrm{v} / \mathrm{v}$ Tween-20) in a 384-well low flange black flat bottom non-binding surface microplate (Corning). Reactions were prepared in triplicate. Fluorescence polarisation was measured using a PHERAstar FSX (BMG Labtech) directly after initial reaction setup and after incubation at room temperature for 30 min and $2 \mathrm{~h}$ to ensure equilibrium had been reached. Error bars indicate the standard deviation of three technical replicates. Data were fitted using Prism 8.0 (GraphPad Software Inc). Dissociation constants were calculated using a two-step model:

$$
F=F_{0}+\frac{F_{L o} \cdot\left[P_{T}\right]}{\left[K_{D L o}\right]+\left[P_{T}\right]}+\frac{F_{H i} \cdot\left[P_{T}\right]}{\left[K_{D H i}\right]+\left[P_{T}\right]}
$$

where $F_{L o}$ and $F_{H i}$ are the anisotropy changes at saturation of low and high affinity sites with binding constants of $K_{D L o}$ and $K_{D H i}$, respectively. Binding constants were averaged from 5 replicates and are given as mean \pm SEM.

\section{Fluorescence detection system-analytical ultracentrifugation (FDS-AUC)}

Peptides $\mathrm{EcFtsN}^{1-32}-\mathrm{C}$ and $\mathrm{VmFtsN}^{1-29}-\mathrm{C}$ were labelled with maleimide-Atto 495 (Merck Life Science UK). EcFtsA $\mathrm{A}^{1-405}$ and $\mathrm{VmFtsA}^{1-396}$ were buffer exchanged into

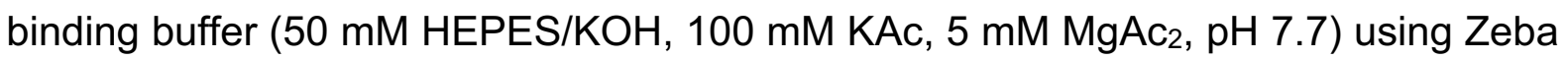
Spin Desalting Columns $(0.5 \mathrm{ml}, 7 \mathrm{kDa}$ MWCO, ThermoFisher) prior to FDS-AUC experiments. $20 \mathrm{nM}$ labelled peptide was mixed 1:1 with a 1:3 dilution series of protein with initial concentrations of $90 \mu \mathrm{M}$ for $\mathrm{EcFts}^{1-405}$ or $120 \mu \mathrm{M}$ for $\mathrm{VmFtsA}{ }^{1-396}$ in binding buffer supplemented with Tween (50 mM HEPES/KOH, $100 \mathrm{mM} \mathrm{KAc,} 5 \mathrm{mM} \mathrm{MgAc} 2$, $\mathrm{pH} 7.7,0.05 \% \mathrm{v} / \mathrm{v}$ Tween-20). Samples were centrifuged at $45,000 \mathrm{rpm}$ at $20^{\circ} \mathrm{C}$ in an An50Ti rotor using an Optima XL-I analytical ultracentrifuge (Beckman) equipped with a fluorescence optical system (Aviv Biomedical) with fixed excitation at $488 \mathrm{~nm}$ and 
bioRxiv preprint doi: https://doi.org/10.1101/2021.11.08.467742; this version posted November 8,2021 . The copyright holder for this preprint (which was not certified by peer review) is the author/funder, who has granted bioRxiv a license to display the preprint in perpetuity. It is made available under aCC-BY 4.0 International license.

FtsA-FtsN antiparallel double filaments

Nierhaus 2021

fluorescence detection at $>505 \mathrm{~nm}$. Data were processed and analysed using SEDFIT 16 and SEDPHAT 15.2 (Schuck, 2003) according to the published protocol for high-affinity interactions detected by fluorescence (Chaturvedi et al., 2017). Binding constants were estimated using a two-step model. Data were plotted using GUSSI (Brautigam, 2015).

\section{Co-pelleting assay}

EcFtsA ${ }^{1-405}$ or $V m F t s A^{1-396}$ at $1 \mathrm{mg} / \mathrm{ml}(\sim 23 \mu \mathrm{M})$ alone or mixed with half, 1-, 3-, 6- or 10-fold the concentration of EcFtsN $\mathrm{N}^{1-32}$ or $\mathrm{VmFtsN}^{1-29}$, respectively, in binding buffer (50 mM HEPES/KOH, $100 \mathrm{mM} \mathrm{KAc,} 5 \mathrm{mM} \mathrm{MgAc} 2$, $\mathrm{pH}$ 7.7) was incubated at room temperature for $5-15 \mathrm{~min}$ before centrifugation at $20,000 \mathrm{xg}$ for $10 \mathrm{~min}$ at $20^{\circ} \mathrm{C}$. Supernatant and pellet fractions were separated carefully and analysed by SDS-PAGE. Protein band intensities were quantified using ImageJ 2.1.0 (Abràmoff et al., 2004). Given are mean \pm sd of two technical replicates for EcFtsA ${ }^{1-405}$ and VmFtsA ${ }^{1-396}$, respectively.

\section{Lipid monolayer assays and negative stain electron microscopy}

Two-dimensional lipid monolayers were prepared from E. coli polar lipid extract (Avanti Polar Lipids) (Ford et al., 2001; Levy et al., 1999). Wells of a custom-made Teflon block were filled with $60 \mu$ l binding buffer (50 mM HEPES/KOH, $100 \mathrm{mM} \mathrm{KAc}$, $5 \mathrm{mM} \mathrm{MgAc}_{2}, \mathrm{pH}$ 7.7). $20 \mu \mathrm{g}$ of lipids, dissolved in chloroform, were applied on top of the buffer, and incubated for 2-3 min to allow evaporation of chloroform. Next, baked $\left(60^{\circ} \mathrm{C}\right.$, overnight) $\mathrm{CF} 300-\mathrm{Cu}-\mathrm{UL}$ EM grids (Electron Microscopy Sciences) were placed on top of the wells with the carbon side facing downwards. Grids were incubated for $20-60$ min to allow formation and attachment of the lipid monolayer to 
bioRxiv preprint doi: https://doi.org/10.1101/2021.11.08.467742; this version posted November 8,2021 . The copyright holder for this preprint (which was not certified by peer review) is the author/funder, who has granted bioRxiv a license to display the preprint in perpetuity. It is made available under aCC-BY 4.0 International license.

FtsA-FtsN antiparallel double filaments

Nierhaus 2021

the grid. In the meantime, full-length FtsA protein at $0.1 \mathrm{mg} / \mathrm{ml}(\sim 2.2 \mu \mathrm{M})$ for EcFtsA, $E_{c F t s A}{ }^{E 124 A}, E c F t s A^{1143 L}, E c F t s A^{G 50 E}$ and $E c F t s A^{R 286 W / E c F t s A *}$ or at $0.2 \mathrm{mg} / \mathrm{ml}$ $(\sim 4.4 \mu \mathrm{M})$ for EcFtsA ${ }^{\mathrm{M} 96 \mathrm{E}, \mathrm{R} 153 \mathrm{D}}$ and $\mathrm{VmFtsA}$ was mixed with $1 \mathrm{mM}$ ATP and indicated FtsN peptides at 10 -fold molar excess, if not stated otherwise, in binding buffer (50 mM HEPES/KOH, 100 mM KAc, 5 mM MgAc 2 , pH 7.7). Samples were incubated for 10 min at RT. EM grids were carefully lifted off the buffer and blotted from the side using Whatman No1 filter paper. $4 \mu \mathrm{l}$ sample were applied to the carbon side of an EM grid and incubated for $30 \mathrm{~s}$ before staining with $2 \% \mathrm{w} / \mathrm{v}$ uranyl formate. Grids were imaged on a Tecnai Spirit electron microscope (ThermoFisher) operating at $120 \mathrm{kV}$ and equipped with a Gatan Orius SC200W camera. Presented micrographs were contrast adjusted and blurred for display purposes.

\section{Cryo-EM of EcFtsA-Fts $\mathbf{N}^{1-32}$ double filaments on lipid monolayer}

Lipid monolayers were prepared as described above, with the exception that Quantifoil Au R0.6/1 300 mesh grids (Quantifoil) were used. EcFtsA at $0.1 \mathrm{mg} / \mathrm{ml}(\sim 2.2 \mu \mathrm{M})$ was mixed with $1 \mathrm{mM}$ ATP and EcFtsN $\mathrm{N}^{1-32}$ at $22 \mu \mathrm{M}$ in binding buffer $(50 \mathrm{mM} \mathrm{HEPES/KOH}$, $100 \mathrm{mM} \mathrm{KAc}, 5 \mathrm{mM} \mathrm{MgAc} 2, \mathrm{pH} 7.7$ ), and incubated for 20 min at RT. Grids were blotted from the side after attachment of the monolayer using Whatman No 1 filter paper and inserted into a Vitrobot Mark III (ThermoFisher) set to $20^{\circ} \mathrm{C}$ and $100 \%$ humidity. $3 \mu \mathrm{l}$ of mixed protein sample were applied to the carbon side of the grid, incubated for $30 \mathrm{~s}$ and blotted for $12-15 \mathrm{~s}$ ( $0.5 \mathrm{~s}$ drain time, -15 blot force) before plunge-freezing into liquid ethane maintained at $-180^{\circ} \mathrm{C}$ using a cryostat (Russo et al., 2016). Grids were imaged using a Tecnai G2 Polara (ThermoFisher) operating at $300 \mathrm{kV}$. Movies were collected on a Falcon III direct electron detector at a pixel size of $1.38 \AA,-3.3$ to $-4 \mu \mathrm{m}$ defocus and a total dose of $100 \mathrm{e}^{-} / \AA^{2}$ using EPU 
bioRxiv preprint doi: https://doi.org/10.1101/2021.11.08.467742; this version posted November 8,2021 . The copyright holder for this preprint (which was not certified by peer review) is the author/funder, who has granted bioRxiv a license to display the preprint in perpetuity. It is made available under aCC-BY 4.0 International license.

FtsA-FtsN antiparallel double filaments

Nierhaus 2021

(ThermoFisher) for automated acquisition. Data were processed using MotionCor2 (Zheng et al., 2017), CTFFIND4 (Rohou and Grigorieff, 2015) and RELION3 (Zivanov et al., 2018). A total of 104,660 particles were automatically picked and extracted, with the presented 2D class average corresponding to 14,602 particles (Figure 2e). Presented micrographs were contrast adjusted and blurred for display purposes.

\section{Multiple sequence alignment}

Annotated FtsA (TIGR01174) and FtsN (TIGR02223) sequences from 2110 bacterial genomes were retrieved from the AnnoTree server (Haft et al., 2001; Mendler et al., 2019; Parks et al., 2018). Genomes with multiple or short FtsA or FtsN sequences were removed. The remaining $1983 \mathrm{FtsN}$ sequences were aligned using Clustal Omega (Sievers et al., 2011). Only sequence stretches corresponding to FtsN's cytoplasmic and transmembrane domain ( $\mathrm{FtsN}^{\text {cyto-TM}}$ ) were used for analysis, corresponding to $\mathrm{EcFtsN}^{1-54}$ for example. Only $\mathrm{FtsN}^{\text {cyto-TM }}$ sequences with a length between 44 and 64 amino acids and a sequence identity to EcFtsNcyto-TM $\geq 35 \%$ were retained if the sequence identity of the corresponding FtsA sequence to E. coli FtsA also was $\geq 70 \%$. The remaining $245 \mathrm{FtsN}^{\text {cyto-TM }}$ sequences were aligned using Muscle (Edgar, 2004). The sequence logo was created using Weblogo 3.7.4 (Crooks et al., 2004).

\section{Hydrogen deuterium exchange mass spectrometry (HDX-MS)}

VmFtsA ${ }^{1-396}$ at $10 \mu \mathrm{M}$ was mixed with $2 \mathrm{mM}$ ATP and, if indicated, $\mathrm{VmFts}^{1-29}$ at 3- (30 $\mu \mathrm{M})$ or 10 -fold $(100 \mu \mathrm{M})$ molar excess in binding buffer (50 mM HEPES/KOH, $100 \mathrm{mM}$ $\left.\mathrm{KAc}, 5 \mathrm{mM} \mathrm{MgAc}_{2}, \mathrm{pH} 7.7\right) .5 \mu \mathrm{L}$ of protein solution were added to $40 \mu \mathrm{L}$ of $\mathrm{D}_{2} \mathrm{O}$ buffer at room temperature for $3,30,300$ and 1800 seconds. Reactions were quenched and 
bioRxiv preprint doi: https://doi.org/10.1101/2021.11.08.467742; this version posted November 8, 2021. The copyright holder for this preprint (which was not certified by peer review) is the author/funder, who has granted bioRxiv a license to display the preprint in perpetuity. It is made available under aCC-BY 4.0 International license.

FtsA-FtsN antiparallel double filaments

Nierhaus 2021

frozen until further processing. Quenched protein samples were rapidly thawed and subjected to proteolytic cleavage by pepsin followed by reversed phase HPLC separation. Briefly, the protein was passed through a $2.1 \times 30 \mathrm{~mm}, 5 \mu \mathrm{m}$ Enzymate BEH immobilised pepsin column (Waters, UK) at $200 \mu \mathrm{L} / \mathrm{min}$ for $2 \mathrm{~min}$. Peptic peptides were trapped and desalted on a $2.1 \times 5$ mm C18 trap column (Acquity BEH C18 Vanguard pre-column, $1.7 \mu \mathrm{m}$, Waters, UK). Trapped peptides were subsequently eluted over 12 min using a 5-36\% gradient of acetonitrile in $0.1 \% \mathrm{v} / \mathrm{v}$ formic acid at $40 \mu \mathrm{L} / \mathrm{min}$. Peptides were separated on a $100 \mathrm{~mm} \times 1 \mathrm{~mm}, 1.7 \mu \mathrm{m}$ Acquity UPLC BEH C18 reverse phase column (Waters, UK). Peptides were detected on a SYNAPT G2-Si HDMS mass spectrometer (Waters, UK) acquiring over a $\mathrm{m} / \mathrm{z}$ range of 300 to 2000 , with standard electrospray ionisation (ESI) source and lock mass calibrated using [Glu1]-fibrino peptide B $(50 \mathrm{fmol} / \mu \mathrm{L})$. The mass spectrometer was operated at a source temperature of $80^{\circ} \mathrm{C}$ and a spray voltage of $2.6 \mathrm{kV}$. Spectra were collected in positive ion mode. Peptides were identified by $\mathrm{MS}^{\mathrm{e}}$ (Silva et al., 2005) using a 5-36\% gradient of acetonitrile in $0.1 \% \mathrm{v} / \mathrm{v}$ formic acid over $12 \mathrm{~min}$. The resulting MS data were analysed using Protein Lynx Global Server software (Waters, UK) with an MS tolerance of $5 \mathrm{ppm}$. Mass analysis of the peptide centroids was performed using DynamX software (Waters, UK). Only peptides with a score $>6.4$ were considered. The first round of analysis and identification was performed automatically by the DynamX software; however, all peptides (deuterated and non-deuterated) were manually verified at every time point for the correct charge state, presence of overlapping peptides, and correct retention time. Deuterium incorporation was not corrected for back-exchange and represents relative, rather than absolute changes in deuterium levels. Changes in H/D amide exchange in any peptide may be due to a single or multiple amides within that peptide. Time points were prepared in parallel 
bioRxiv preprint doi: https://doi.org/10.1101/2021.11.08.467742; this version posted November 8,2021 . The copyright holder for this preprint (which was not certified by peer review) is the author/funder, who has granted bioRxiv a license to display the preprint in perpetuity. It is made available under aCC-BY 4.0 International license.

FtsA-FtsN antiparallel double filaments

Nierhaus 2021

and data for individual time points were acquired on the mass spectrometer on the same day.

\section{Nuclear magnetic resonance (NMR) spectroscopy}

Backbone amide peaks of $\mathrm{mmFtsN}^{1-29}$-ENLYFQ were assigned using $167 \mu \mathrm{M}{ }^{15} \mathrm{~N},{ }^{13} \mathrm{C}$ labelled peptide at $278 \mathrm{~K}$ in NMR buffer (50 mM MES/KOH, $50 \mathrm{mM} \mathrm{KCl,} 1 \mathrm{mM}$ TCEP, $\mathrm{pH}$ 6.0). Standard triple resonance spectra: HNCO, HN(CA)CO, HNCACB, and $\mathrm{CBCA}(\mathrm{CO}) \mathrm{NH}$ (Bruker) were collected with $20 \%$ non-uniform sampling and processed with compressed sensing using the MddNMR package (Jaravine et al., 2008). Backbone resonances were assigned using MARS (Jung and Zweckstetter, 2004). Topspin 3.6.0 (Bruker) was used for processing of 2D data and NMRFAMSparky 1.47 (Lee et al., 2015) was used for spectra analysis. Assignment of VmFtsN ${ }^{1-29}$-ENLYFQ was transferred to Gly-Gly-VmFtsN ${ }^{2-29}$ using $295 \mu \mathrm{M}{ }^{15} \mathrm{~N}-$ labelled peptide at $278 \mathrm{~K}$ in NMR buffer. Gly1, Ala2 and Asn3, which were not observed for VmFtsN ${ }^{1-29}$-ENLYFQ, were newly assigned. The first glycine (G0) of GlyGly-VmFtsN ${ }^{2-29}$ was not observed.

For binding studies, ${ }^{1} \mathrm{H},{ }^{15} \mathrm{~N}$ BEST-TROSY spectra were acquired at $278 \mathrm{~K}$ on $50 \mu \mathrm{M}$ Gly-Gly-VmFtsN ${ }^{2-29}$ mixed with an equimolar concentration of $\mathrm{VmFts}^{1-396}$ in NMR buffer. As sensitivity was compromised by the formation of FtsA polymers upon binding of FtsN peptide, multiple short experiments were acquired and added up to define the ideal time window for data analysis. Each spectrum was acquired with 128 scans and a recycle delay of $400 \mathrm{~ms}$, with a final spectral resolution of $4.7 \mathrm{~Hz}$ per points. Relative peak intensities were normalised to the C-terminal residue Arg29 of Gly-Gly-VmFtsN ${ }^{2-29}$ and analysed as $I_{\text {bound }} / I_{\text {free, }}$ with $I_{\text {bound }}$ and $I_{\text {free }}$ being the peak 
bioRxiv preprint doi: https://doi.org/10.1101/2021.11.08.467742; this version posted November 8, 2021. The copyright holder for this preprint (which was not certified by peer review) is the author/funder, who has granted bioRxiv a license to display the preprint in perpetuity. It is made available under aCC-BY 4.0 International license.

FtsA-FtsN antiparallel double filaments

Nierhaus 2021

intensities of Gly-Gly-VmFtsN ${ }^{2-29}$ with (bound) and without (free) VmFtsA ${ }^{1-396}$, respectively.

\section{EcFtsA-FtsN ${ }^{1-32}$ filaments on liposomes}

Liposomes were prepared from E. coli polar lipid extract (Avanti Polar Lipids) by extrusion using a Mini Extruder fitted with a polycarbonate membrane with $1 \mu \mathrm{m}$ pore size (Avanti Polar Lipids) in binding buffer without magnesium (50 mM HEPES/KOH, $100 \mathrm{mM} \mathrm{KAc}, \mathrm{pH} 7.7$ ). Preformed liposomes at $1 \mathrm{mg} / \mathrm{ml}$ were mixed with $0.5 \mathrm{mM}$ MgATP and proteins at the following concentrations: no proteins (Figure 4a, left), FtsA at $20 \mu \mathrm{M}$ and $\mathrm{FtsN}^{1-32}$ at $200 \mu \mathrm{M}$ (Figure $4 \mathrm{a}$, top right) and FtsA at $5 \mu \mathrm{M}$ and $\mathrm{FtsN}^{1-32}$ at $50 \mu \mathrm{M}$ (Figure 4a, bottom right). Samples were incubated at room temperature for $30 \mathrm{~min}$ without proteins or $10 \mathrm{~min}$ with proteins, respectively. $3 \mu \mathrm{l}$ of sample were applied to a freshly glow-discharged Quantifoil Au R2/2 200 mesh grid (Quantifoil), blotted for 3.5-7.5 s (0.5 s drain time, -15 blot force) and plunge-frozen into liquid ethane maintained at $-180^{\circ} \mathrm{C}$ using a cryostat (Russo et al., 2016) using a Vitrobot Mark III (ThermoFisher) set to $20^{\circ} \mathrm{C}$ and $100 \%$ humidity. Grids were imaged on a Tecnai F20 (ThermoFisher) equipped with a Falcon II direct electron detector or a Glacios (ThermoFisher) equipped with a Falcon III detector. Microscopes were operated at $200 \mathrm{kV}$ and cryogenic temperature. Presented micrographs were motioncorrected (if collected on the Glacios), contrast adjusted and blurred for display purposes.

\section{EcFtsA-Fts $N^{1-32}$ filaments inside liposomes}

EcFtsA-FtsN ${ }^{1-32}$ filaments were encapsulated into liposomes by dilution of CHAPSsolubilised E. coli total lipid extract (Avanti Polar Lipids) (Szwedziak et al., 2014). 50 l 
bioRxiv preprint doi: https://doi.org/10.1101/2021.11.08.467742; this version posted November 8, 2021. The copyright holder for this preprint (which was not certified by peer review) is the author/funder, who has granted bioRxiv a license to display the preprint in perpetuity. It is made available under aCC-BY 4.0 International license.

FtsA-FtsN antiparallel double filaments

Nierhaus 2021

of preincubated FtsA at $20 \mu \mathrm{M}$ mixed with $200 \mu \mathrm{M} \mathrm{FtsN}^{1-32}$ and $0.5 \mathrm{mM}$ MgATP in binding buffer without magnesium (50 mM HEPES/KOH, $100 \mathrm{mM} \mathrm{KAc,} \mathrm{pH} \mathrm{7.7)} \mathrm{were}$ added to $50 \mu$ l of $E$. coli total lipid extract (Avanti Polar Lipids) solubilised at $10 \mathrm{mg} / \mathrm{ml}$ in binding buffer without magnesium supplemented with $20 \mathrm{mM}$ CHAPS (50 mM HEPES/KOH, $100 \mathrm{mM} \mathrm{KAc,} \mathrm{pH} \mathrm{7.7,} 20$ mM CHAPS). The sample was incubated at room temperature for $35 \mathrm{~min}$, before it was gradually diluted with $500 \mu \mathrm{l}$ of binding buffer without magnesium supplemented with $0.5 \mathrm{mM}$ MgATP (50 mM HEPES/KOH, $100 \mathrm{mM} \mathrm{KAc}, \mathrm{pH} 7.7,0.5 \mathrm{mM}$ MgATP) within $20 \mathrm{~min} .3 \mu \mathrm{l}$ of sample were applied to a freshly glow-discharged Quantifoil Au R2/2 200 mesh grid (Quantifoil), blotted for 5.57.5 s (0.5 s drain time, -15 blot force) and plunge-frozen into liquid ethane maintained at $-180^{\circ} \mathrm{C}$ using a cryostat (Russo et al., 2016) using a Vitrobot Mark III (ThermoFisher) set to $20^{\circ} \mathrm{C}$ and $100 \%$ humidity. Grids were imaged on a Tecnai F20 (ThermoFisher) equipped with a Falcon II direct electron detector, operating at $200 \mathrm{kV}$ and cryogenic temperature. Rarely, EcFtsA-FtsN ${ }^{1-32}$ filaments were observed inside liposomes when added to the outside of preformed liposomes (Figure 4d), most likely due to membrane rearrangements during handling. Here, preformed liposomes extruded to $1 \mu \mathrm{m}$ at 1 $\mathrm{mg} / \mathrm{ml}$ were mixed with $0.5 \mathrm{mM} \mathrm{MgATP}$, FtsA at $2.5 \mu \mathrm{M}$ and $\mathrm{FtsN}^{1-32}$ at $25 \mu \mathrm{M}$. Presented micrographs were contrast adjusted and blurred for display purposes. For 2D class averages (Figure 4e), movies were collected on a Glacios with a Falcon III at a pixel size of $1.99 \AA,-2.5$ to $-4 \mu \mathrm{m}$ defocus and a total dose of $56 \mathrm{e}^{-} / \AA^{2}$ using SerialEM (Mastronarde, 2005). Data were processed using MotionCor2 (Zheng et al., 2017), CTFFIND4.1 (Rohou and Grigorieff, 2015) and RELION-3.1 (Zivanov et al., 2018). Presented images were upscaled and blurred for display purposes. 
bioRxiv preprint doi: https://doi.org/10.1101/2021.11.08.467742; this version posted November 8,2021 . The copyright holder for this preprint (which was not certified by peer review) is the author/funder, who has granted bioRxiv a license to display the preprint in perpetuity. It is made available under aCC-BY 4.0 International license.

FtsA-FtsN antiparallel double filaments

Nierhaus 2021

\section{Strain construction}

The general cloning and recombination strategy is illustrated in Supplementary Figure S4a. The helper plasmid pKW20 (NCBI ID: MN927219.1) (Wang et al., 2016) was used for genome engineering. pKW20 encodes for a constitutively expressed tracrRNA as well as Cas 9 and $\lambda$-Red components under control of a L-arabinoseinducible promotor. Acceptor strain SFB123 was created by integrating a phe $S^{T 251 A, A 294 G}$-hygR double selection cassette downstream of the IpxC gene using $\lambda$ Red recombineering (Yu et al., 2000). phe $S^{T 251 A, A 294 G} / p h e S^{*}$ is a negative selection marker encoding a mutant phenylalanyl-tRNA synthetase that confers toxicity through misincorporation of 4-chloro-phenylalanine (4-CP) during translation (Miyazaki, 2015). We found a long $(5 \mathrm{kB})$ homologous region upstream of FtsA to benefit recombination efficiency. SFB143 was used as donor strain during conjugation. SFB143 is an E. coli MDS42 thi strain transformed with the non-transferrable conjugative plasmid pJF146 (NCBI ID: MK809154.1) (Fredens et al., 2019). pJF146 bears an apR resistance marker and a truncated nick site of the origin of transfer. SFB143 cells were made chemically competent enabling parallelised transformation (Inoue et al., 1990).

Shuttle plasmid pFB483 was designed with a pMB1 origin of replication, a pheS ${ }^{T 251 A, A 294 G}$-hygR double selection cassette, a CRISPR array targeting ftsW and the region just upstream of $\sec M$, and a $c c d B$ toxin gene (outsert) flanked by Bsal acceptor sites via Golden Gate assembly (Engler et al., 2008). CRISPR arrays were designed to mediate scarless excision. pFB483 was propagated in a ccdB survival strain.

Targeting constructs were split into 2-3 modules for insertion of single or double point mutations, respectively. Initially, the internal 3x HA-tag (120 bp including a Xhol restriction site) was inserted into ftsA using three modules, resulting in sTN001 
bioRxiv preprint doi: https://doi.org/10.1101/2021.11.08.467742; this version posted November 8, 2021. The copyright holder for this preprint (which was not certified by peer review) is the author/funder, who has granted bioRxiv a license to display the preprint in perpetuity. It is made available under aCC-BY 4.0 International license.

FtsA-FtsN antiparallel double filaments

Nierhaus 2021

(ftsA269-3x HA-tag-270(SW), IpxC::neoR), and propagated in modules in the following. Point mutations were introduced by PCR and modules assembled into pFB483 via Golden Gate assembly with Bsal. The final targeting construct also introduced a kanamycin-selectable neoR marker downstream of the $I p x C$ gene. Assembled shuttle vectors were transformed into SFB143 and selected on LB agar plates supplemented with $200 \mu \mathrm{g} / \mathrm{ml}$ hygromycin-B and $50 \mu \mathrm{g} / \mathrm{ml}$ apramycin at $37^{\circ} \mathrm{C}$. Acceptor cells (SFB123) were grown to stationary phase in $5 \mathrm{ml}$ LB supplemented with $10 \mu \mathrm{g} / \mathrm{ml}$ tetracycline. $4 \mathrm{ml}$ of culture were harvested by centrifugation and washed three times in LB, before being transferred into $50 \mathrm{ml}$ LB supplemented with $10 \mu \mathrm{g} / \mathrm{ml}$ tetracycline and $0.5 \% \mathrm{w} / \mathrm{v}$ L-arabinose. Cells were grown at $37^{\circ} \mathrm{C}$ for $1 \mathrm{~h}$, harvested by centrifugation and washed three times in LB. In the meantime, donor transformants were washed off the agar plates using $2 \mathrm{ml} \mathrm{LB}$ and left at room temperature. All cultures were resuspended in LB to an $\mathrm{OD}_{600}$ of $40.12 .5 \mu \mathrm{l}$ of acceptor cells were mixed $87.5 \mu$ l of donor cells and spotted onto well-dried TYE plates in 10-20 $\mu$ l drops. Spots were air-dried, before plates were incubated at $30^{\circ} \mathrm{C}$ for $1 \mathrm{~h}$. Cells were washed off the plates with LB and transferred into 50 LB supplemented with $12.5 \mu \mathrm{g} / \mathrm{ml}$ kanamycin and $10 \mu \mathrm{g} / \mathrm{ml}$ tetracycline. Cells were grown at $37^{\circ} \mathrm{C}$ for $1 \mathrm{~h}$, harvested by centrifugation and plated on LB agar plates supplemented with $12.5 \mu \mathrm{g} / \mathrm{ml}$ kanamycin, $10 \mu \mathrm{g} / \mathrm{ml}$ tetracycline, $2 \%$ glucose and $2.5 \mathrm{mM} \mathrm{4-CP.} \mathrm{Strains} \mathrm{were} \mathrm{single} \mathrm{colony}$ purified, and verified by marker analysis and colony PCR followed by Xhol digestion and Sanger sequencing. Strains with desired point mutations were cured of pKW20 by repeated growth in LB in absence of antibiotics, diluted $1: 10^{6}$ and plated on TYE plates. pKW20 was typically lost in one of eight cells after 2-3 growth cycles. Strains were verified by marker analysis and Sanger sequencing of PCR products covering the targeting region. Strains used in Figure $5 c$ were further whole genome sequenced 
bioRxiv preprint doi: https:/doi.org/10.1101/2021.11.08.467742; this version posted November 8, 2021. The copyright holder for this preprint (which was not certified by peer review) is the author/funder, who has granted bioRxiv a license to display the preprint in perpetuity. It is made available under aCC-BY 4.0 International license.

FtsA-FtsN antiparallel double filaments

Nierhaus 2021

on a MiSeq (Illumina). NGS data were analysed using breseq v0.35.1 (Deatherage and Barrick, 2014).

Strains are listed in Supplementary Table T 5.

\section{Assessment of growth and cell elongation phenotypes}

Growth on solid media

Strains were streaked on the same TYE plate and incubated at $37^{\circ} \mathrm{C}$ overnight. The next morning, strains were re-streaked on a fresh TYE plate and incubated at $37^{\circ} \mathrm{C}$ for $12 \mathrm{~h}$.

Growth in liquid media

Strains were inoculated into $5 \mathrm{ml} \mathrm{LB}$ and incubated at $37^{\circ} \mathrm{C}$ overnight. Cells were diluted $1 / 1000$ into fresh LB into a 96 -well flat bottom plate in octuplicate. The plate was incubated at $37^{\circ} \mathrm{C}$ in a Tecan microplate reader with regular shaking. Absorbance at $600 \mathrm{~nm}$ wavelength was measured every $5 \mathrm{~min}$ for $24 \mathrm{~h}$. $\mathrm{OD}_{600}$ values were background corrected, normalised to the maximum $\mathrm{OD}_{600}$ value of each well, averaged and plotted as mean \pm sd

DIC imaging of exponential phase cultures

Strains were inoculated into $5 \mathrm{ml} \mathrm{LB}$ and incubated at $37^{\circ} \mathrm{C}$ overnight. The next day, cells were diluted $1 / 1000$ in $5 \mathrm{ml}$ fresh medium and incubated at $37^{\circ} \mathrm{C}$. 2-3 $\mu \mathrm{l}$ of exponential phase cells $\left(\mathrm{OD}_{600}=0.2-0.3\right)$ were applied onto an agarose pad and imaged on a Nikon Eclipse E800 microscope equipped with a 100x oil objective and a Photometrics Iris 9 CMOS camera using a differential interference contrast (DIC) imaging setup. Presented images were contrast-adjusted for display purposes. 
bioRxiv preprint doi: https://doi.org/10.1101/2021.11.08.467742; this version posted November 8,2021 . The copyright holder for this preprint (which was not certified by peer review) is the author/funder, who has granted bioRxiv a license to display the preprint in perpetuity. It is made available under aCC-BY 4.0 International license.

FtsA-FtsN antiparallel double filaments

Nierhaus 2021

\section{In vivo cysteine cross-linking}

Strains were grown to exponential phase $\left(\mathrm{OD}_{600}=0.2-0.4\right)$ and $0.9375 \mathrm{OD}$ units harvested using centrifugation at $4^{\circ} \mathrm{C}$. Cells were kept on ice for the duration of the experiment, unless stated otherwise. Cells were washed in $500 \mu \mathrm{l} \mathrm{PBS}$, spun and resuspended in $50 \mu$ l PBS. $1.25 \mu$ LMSO or cross-linker (dBBr: Dibromobimane, BMOE: Bismaleimidoethane, BMB: 1,4-bismaleimidobutane or $\mathrm{BMH}$ : Bismaleimidohexane) in DMSO (20 mM stock) were added. Samples were incubated for $10 \mathrm{~min}$ and quenched by adding $1 \mu$ l 2-mercaptoethanol (2-ME, $1.43 \mathrm{M}$ stock in MPW). Cells were spun and resuspended in $50 \mu$ lysis buffer [1 mM EDTA ( $\mathrm{pH} 7.4), 14.3 \mathrm{mM}$ 2-ME, cOmplete EDTA-free Protease Inhibitor Cocktail (Roche), $0.25 \mathrm{U} / \mu \mathrm{l}$ Benzonase (Merck) and $0.5 \mathrm{U} / \mu \mathrm{l}$ ReadyLyse Lysozyme (Lucigen) in B-PER (ThermoFisher)]. Samples were incubated at room temperature for $5 \mathrm{~min} .50 \mu \mathrm{l}$ of $2 x$ SDS sample loading buffer supplemented with $3 \%$ v/v 2-ME were added. Samples were incubated at $95^{\circ} \mathrm{C}$ for $5 \mathrm{~min}$, and the equivalent of $0.1875 \mathrm{OD}$ units of cells was loaded onto a gel and analysed by SDS-PAGE. Western blotting was performed using a Trans-Blot turbo (BioRad) with the corresponding Midi $0.2 \mu \mathrm{m}$ PVDF transfer pack. Blots were run at $25 \mathrm{~V}$ and $2.5 \mathrm{~A}$ for $7 \mathrm{~min}$ (mixed molecular weight programme). Membranes were blocked in PBS $+5 \%$ milk for 30-40 min, washed in PBS and incubated with anti-HA-Peroxidase antibody (Roche 12013819001) (1/1000 in PBST + $5 \%$ milk) at room temperature for 1-1.5h. Membranes were washed thoroughly with PBS and developed using the ECL Prime Western blotting detection kit (Amersham/Cytiva). Western blots were imaged on a Gel DocTM XR+ (Bio-Rad). Presented images were contrast-adjusted for display purposes. 
bioRxiv preprint doi: https://doi.org/10.1101/2021.11.08.467742; this version posted November 8,2021 . The copyright holder for this preprint (which was not certified by peer review) is the author/funder, who has granted bioRxiv a license to display the preprint in perpetuity. It is made available under aCC-BY 4.0 International license.

FtsA-FtsN antiparallel double filaments

Nierhaus 2021

\section{REFERENCES}

Abràmoff, M. D., P. J. Magalhães and S. J. Ram (2004). Image processing with ImageJ. Biophotonics international 11: 36-42.

Afonine, P. V., B. K. Poon, R. J. Read, O. V. Sobolev, T. C. Terwilliger, A. Urzhumtsev and P. D. Adams (2018). Real-space refinement in PHENIX for cryo-EM and crystallography. Acta Crystallogr D Struct Biol 74: 531-544.

Baranova, N., P. Radler, V. M. Hernandez-Rocamora, C. Alfonso, M. Lopez-Pelegrin, G. Rivas, W. Vollmer and M. Loose (2020). Diffusion and capture permits dynamic coupling between treadmilling FtsZ filaments and cell division proteins. Nat Microbiol

Bendezu, F. O., C. A. Hale, T. G. Bernhardt and P. A. de Boer (2009). RodZ (YfgA) is required for proper assembly of the MreB actin cytoskeleton and cell shape in $\mathrm{E}$. coli. EMBO J 28: 193-204.

Bernard, C. S., M. Sadasivam, D. Shiomi and W. Margolin (2007). An altered FtsA can compensate for the loss of essential cell division protein FtsN in Escherichia coli. Mol Microbiol 64: 1289-305.

Bisson-Filho, A. W., Y. P. Hsu, G. R. Squyres, E. Kuru, F. Wu, C. Jukes, Y. Sun, C. Dekker, S. Holden, M. S. VanNieuwenhze, Y. V. Brun and E. C. Garner (2017). Treadmilling by FtsZ filaments drives peptidoglycan synthesis and bacterial cell division. Science 355: 739-743.

Boes, A., S. Olatunji, E. Breukink and M. Terrak (2019). Regulation of the Peptidoglycan Polymerase Activity of PBP1b by Antagonist Actions of the Core Divisome Proteins FtsBLQ and FtsN. mBio 10

Brautigam, C. A. (2015). Calculations and Publication-Quality Illustrations for Analytical Ultracentrifugation Data. Methods Enzymol 562: 109-33.

Busiek, K. K., J. M. Eraso, Y. Wang and W. Margolin (2012). The early divisome protein FtsA interacts directly through its 1c subdomain with the cytoplasmic domain of the late divisome protein FtsN. J Bacteriol 194: 1989-2000. 
bioRxiv preprint doi: https://doi.org/10.1101/2021.11.08.467742; this version posted November 8,2021 . The copyright holder for this

preprint (which was not certified by peer review) is the author/funder, who has granted bioRxiv a license to display the preprint in perpetuity. It is made available under aCC-BY 4.0 International license.

FtsA-FtsN antiparallel double filaments

Nierhaus 2021

Busiek, K. K. and W. Margolin (2014). A role for FtsA in SPOR-independent localization of the essential Escherichia coli cell division protein FtsN. Mol Microbiol 92: 1212-26.

Chaturvedi, S. K., J. Ma, H. Zhao and P. Schuck (2017). Use of fluorescence-detected sedimentation velocity to study high-affinity protein interactions. Nat Protoc 12: 1777-1791.

Cho, H., C. N. Wivagg, M. Kapoor, Z. Barry, P. D. A. Rohs, H. Suh, J. A. Marto, E. C. Garner and T. G. Bernhardt (2016). Bacterial cell wall biogenesis is mediated by SEDS and PBP polymerase families functioning semi-autonomously. Nat Microbiol 1: 16172.

Crooks, G. E., G. Hon, J. M. Chandonia and S. E. Brenner (2004). WebLogo: a sequence logo generator. Genome Res 14: 1188-90.

Deatherage, D. E. and J. E. Barrick (2014). Identification of mutations in laboratoryevolved microbes from next-generation sequencing data using breseq. Methods Mol Biol 1151: 165-88.

Dion, M. F., M. Kapoor, Y. Sun, S. Wilson, J. Ryan, A. Vigouroux, S. van Teeffelen, R. Oldenbourg and E. C. Garner (2019). Bacillus subtilis cell diameter is determined by the opposing actions of two distinct cell wall synthetic systems. Nat Microbiol 4: $1294-1305$.

Du, S. and J. Lutkenhaus (2017). Assembly and activation of the Escherichia coli divisome. Mol Microbiol 105: 177-187.

Du, S. and J. Lutkenhaus (2019). At the Heart of Bacterial Cytokinesis: The Z Ring. Trends Microbiol 27: 781-791.

Edgar, R. C. (2004). MUSCLE: multiple sequence alignment with high accuracy and high throughput. Nucleic Acids Res 32: 1792-7.

Emsley, P., B. Lohkamp, W. G. Scott and K. Cowtan (2010). Features and development of Coot. Acta Crystallogr D Biol Crystallogr 66: 486-501. 
bioRxiv preprint doi: https://doi.org/10.1101/2021.11.08.467742; this version posted November 8,2021 . The copyright holder for this preprint (which was not certified by peer review) is the author/funder, who has granted bioRxiv a license to display the preprint in perpetuity. It is made available under aCC-BY 4.0 International license.

FtsA-FtsN antiparallel double filaments

Nierhaus 2021

Engler, C., R. Kandzia and S. Marillonnet (2008). A one pot, one step, precision cloning method with high throughput capability. PLoS One 3: e3647.

Evans, P. (2006). Scaling and assessment of data quality. Acta Crystallogr D Biol Crystallogr 62: 72-82.

Ford, M. G., B. M. Pearse, M. K. Higgins, Y. Vallis, D. J. Owen, A. Gibson, C. R. Hopkins, P. R. Evans and H. T. McMahon (2001). Simultaneous binding of Ptdlns(4,5)P2 and clathrin by AP180 in the nucleation of clathrin lattices on membranes. Science 291: 1051-5.

Fredens, J., K. Wang, D. de la Torre, L. F. H. Funke, W. E. Robertson, Y. Christova, T. Chia, W. H. Schmied, D. L. Dunkelmann, V. Beranek, C. Uttamapinant, A. G. Llamazares, T. S. Elliott and J. W. Chin (2019). Total synthesis of Escherichia coli with a recoded genome. Nature 569: 514-518.

Fujita, J., Y. Maeda, C. Nagao, Y. Tsuchiya, Y. Miyazaki, M. Hirose, E. Mizohata, Y. Matsumoto, T. Inoue, K. Mizuguchi and H. Matsumura (2014). Crystal structure of FtsA from Staphylococcus aureus. FEBS Lett 588: 1879-85.

Garner, E. C., R. Bernard, W. Wang, X. Zhuang, D. Z. Rudner and T. Mitchison (2011). Coupled, circumferential motions of the cell wall synthesis machinery and MreB filaments in B. subtilis. Science 333: 222-5.

Geissler, B., D. Elraheb and W. Margolin (2003). A gain-of-function mutation in ftsA bypasses the requirement for the essential cell division gene zipA in Escherichia coli. Proc Natl Acad Sci U S A 100: 4197-202.

Gerding, M. A., B. Liu, F. O. Bendezu, C. A. Hale, T. G. Bernhardt and P. A. de Boer (2009). Self-enhanced accumulation of FtsN at Division Sites and Roles for Other Proteins with a SPOR domain (DamX, DedD, and RIpA) in Escherichia coli cell constriction. J Bacteriol 191: 7383-401.

Gorrec, F. and J. Löwe (2018). Automated Protocols for Macromolecular Crystallization at the MRC Laboratory of Molecular Biology. J Vis Exp 
bioRxiv preprint doi: https://doi.org/10.1101/2021.11.08.467742; this version posted November 8,2021 . The copyright holder for this

preprint (which was not certified by peer review) is the author/funder, who has granted bioRxiv a license to display the preprint in perpetuity. It is made available under aCC-BY 4.0 International license.

FtsA-FtsN antiparallel double filaments

Nierhaus 2021

Gorrec, F. (2019). An anticipated optimization approach to macromolecular crystallization. bioRxiv: 620328.

Haft, D. H., B. J. Loftus, D. L. Richardson, F. Yang, J. A. Eisen, I. T. Paulsen and O. White (2001). TIGRFAMs: a protein family resource for the functional identification of proteins. Nucleic Acids Res 29: 41-3.

Hayward, S. and R. A. Lee (2002). Improvements in the analysis of domain motions in proteins from conformational change: DynDom version 1.50. J Mol Graph Model 21: 181-3.

Hussain, S., C. N. Wivagg, P. Szwedziak, F. Wong, K. Schaefer, T. Izore, L. D. Renner, M. J. Holmes, Y. Sun, A. W. Bisson-Filho, S. Walker, A. Amir, J. Löwe and E. C. Garner (2018). MreB filaments align along greatest principal membrane curvature to orient cell wall synthesis. Elife 7

Inoue, H., H. Nojima and H. Okayama (1990). High efficiency transformation of Escherichia coli with plasmids. Gene 96: 23-8.

Jacquier, N., P. H. Viollier and G. Greub (2015). The role of peptidoglycan in chlamydial cell division: towards resolving the chlamydial anomaly. FEMS Microbiol Rev 39: 262-75.

Jaravine, V. A., A. V. Zhuravleva, P. Permi, I. Ibraghimov and V. Y. Orekhov (2008). Hyperdimensional NMR spectroscopy with nonlinear sampling. J Am Chem Soc 130: 3927-36.

Jung, Y. S. and M. Zweckstetter (2004). Mars -- robust automatic backbone assignment of proteins. J Biomol NMR 30: 11-23.

Kabsch, W. (2010). Xds. Acta Crystallogr D Biol Crystallogr 66: 125-32.

Karimova, G., N. Dautin and D. Ladant (2005). Interaction network among Escherichia coli membrane proteins involved in cell division as revealed by bacterial twohybrid analysis. J Bacteriol 187: 2233-43. 
bioRxiv preprint doi: https://doi.org/10.1101/2021.11.08.467742; this version posted November 8,2021 . The copyright holder for this

preprint (which was not certified by peer review) is the author/funder, who has granted bioRxiv a license to display the preprint in perpetuity. It is made available under aCC-BY 4.0 International license.

FtsA-FtsN antiparallel double filaments

Nierhaus 2021

Karuppiah, V. and J. P. Derrick (2011). Structure of the PilM-PiIN inner membrane type IV pilus biogenesis complex from Thermus thermophilus. J Biol Chem 286: 24434-42.

Krupka, M., V. W. Rowlett, D. Morado, H. Vitrac, K. Schoenemann, J. Liu and W. Margolin (2017). Escherichia coli FtsA forms lipid-bound minirings that antagonize lateral interactions between FtsZ protofilaments. Nat Commun 8: 15957.

Laskowski, R. A., M. W. Macarthur, D. S. Moss and J. M. Thornton (1993). Procheck - a Program to Check the Stereochemical Quality of Protein Structures. Journal of Applied Crystallography 26: 283-291.

Lee, W., M. Tonelli and J. L. Markley (2015). NMRFAM-SPARKY: enhanced software for biomolecular NMR spectroscopy. Bioinformatics 31: 1325-7.

Levy, D., G. Mosser, O. Lambert, G. S. Moeck, D. Bald and J. L. Rigaud (1999). Twodimensional crystallization on lipid layer: A successful approach for membrane proteins. J Struct Biol 127: 44-52.

Li, Y., H. Gong, R. Zhan, S. Ouyang, K. T. Park, J. Lutkenhaus and S. Du (2021). Genetic analysis of the septal peptidoglycan synthase FtsWI complex supports a conserved activation mechanism for SEDS-bPBP complexes. PLoS Genet 17: e1009366.

Liu, B., L. Persons, L. Lee and P. A. de Boer (2015). Roles for both FtsA and the FtsBLQ subcomplex in FtsN-stimulated cell constriction in Escherichia coli. Mol Microbiol 95: 945-70.

Marmont, L. S. and T. G. Bernhardt (2020). A conserved subcomplex within the bacterial cytokinetic ring activates cell wall synthesis by the FtsW-FtsI synthase. Proc Natl Acad Sci U S A 117: 23879-23885.

Mastronarde, D. N. (2005). Automated electron microscope tomography using robust prediction of specimen movements. Journal of Structural Biology 152: 36-51. 
bioRxiv preprint doi: https://doi.org/10.1101/2021.11.08.467742; this version posted November 8, 2021. The copyright holder for this

preprint (which was not certified by peer review) is the author/funder, who has granted bioRxiv a license to display the preprint in perpetuity. It is made available under aCC-BY 4.0 International license.

FtsA-FtsN antiparallel double filaments

Nierhaus 2021

McCallum, M., S. Tammam, D. J. Little, H. Robinson, J. Koo, M. Shah, C. Calmettes, T. F. Moraes, L. L. Burrows and P. L. Howell (2016). PilN Binding Modulates the Structure and Binding Partners of the Pseudomonas aeruginosa Type IVa Pilus Protein PilM. J Biol Chem 291: 11003-15.

McCoy, A. J., R. W. Grosse-Kunstleve, P. D. Adams, M. D. Winn, L. C. Storoni and R. J. Read (2007). Phaser crystallographic software. J App/ Crystallogr 40: 658-674.

McQuillen, R. and J. Xiao (2020). Insights into the Structure, Function, and Dynamics of the Bacterial Cytokinetic FtsZ-Ring. Annu Rev Biophys

Mendler, K., H. Chen, D. H. Parks, B. Lobb, L. A. Hug and A. C. Doxey (2019). AnnoTree: visualization and exploration of a functionally annotated microbial tree of life. Nucleic Acids Res 47: 4442-4448.

Miyazaki, K. (2015). Molecular engineering of a PheS counterselection marker for improved operating efficiency in Escherichia coli. Biotechniques 58: 86-8.

Monteiro, J. M., A. R. Pereira, N. T. Reichmann, B. M. Saraiva, P. B. Fernandes, H. Veiga, A. C. Tavares, M. Santos, M. T. Ferreira, V. Macario, M. S. VanNieuwenhze, S. R. Filipe and M. G. Pinho (2018). Peptidoglycan synthesis drives an FtsZ-treadmilling-independent step of cytokinesis. Nature 554: 528-532.

Müller, P., C. Ewers, U. Bertsche, M. Anstett, T. Kallis, E. Breukink, C. Fraipont, M. Terrak, M. Nguyen-Disteche and W. Vollmer (2007). The essential cell division protein FtsN interacts with the murein (peptidoglycan) synthase PBP1B in Escherichia coli. J Biol Chem 282: 36394-402.

Murshudov, G. N., A. A. Vagin and E. J. Dodson (1997). Refinement of macromolecular structures by the maximum-likelihood method. Acta Crystallogr D Biol Crystallogr 53: 240-55.

Nogales, E., K. H. Downing, L. A. Amos and J. Löwe (1998). Tubulin and FtsZ form a distinct family of GTPases. Nat Struct Biol 5: 451-8. 
bioRxiv preprint doi: https://doi.org/10.1101/2021.11.08.467742; this version posted November 8, 2021. The copyright holder for this preprint (which was not certified by peer review) is the author/funder, who has granted bioRxiv a license to display the preprint in perpetuity. It is made available under aCC-BY 4.0 International license.

FtsA-FtsN antiparallel double filaments

Nierhaus 2021

Park, K. T., S. Pichoff, S. Du and J. Lutkenhaus (2021). FtsA acts through FtsW to promote cell wall synthesis during cell division in Escherichia coli. Proc Natl Acad Sci U S A 118

Parks, D. H., M. Chuvochina, D. W. Waite, C. Rinke, A. Skarshewski, P. A. Chaumeil and P. Hugenholtz (2018). A standardized bacterial taxonomy based on genome phylogeny substantially revises the tree of life. Nat Biotechnol 36: 996-1004.

Pichoff, S. and J. Lutkenhaus (2002). Unique and overlapping roles for ZipA and FtsA in septal ring assembly in Escherichia coli. EMBO J 21: 685-93.

Pichoff, S. and J. Lutkenhaus (2005). Tethering the $Z$ ring to the membrane through a conserved membrane targeting sequence in FtsA. Mol Microbiol 55: 1722-34.

Pichoff, S., B. Shen, B. Sullivan and J. Lutkenhaus (2012). FtsA mutants impaired for self-interaction bypass ZipA suggesting a model in which FtsA's self-interaction competes with its ability to recruit downstream division proteins. Mol Microbio/ 83: 151-67.

Pichoff, S., S. Du and J. Lutkenhaus (2015). The bypass of ZipA by overexpression of FtsN requires a previously unknown conserved FtsN motif essential for FtsAFtsN interaction supporting a model in which FtsA monomers recruit late cell division proteins to the $\mathrm{Z}$ ring. Mol Microbiol 95: 971-87.

Pichoff, S., S. Du and J. Lutkenhaus (2018). Disruption of divisome assembly rescued by FtsN-FtsA interaction in Escherichia coli. Proc Natl Acad Sci U S A

Posfai, G., G. Plunkett, 3rd, T. Feher, D. Frisch, G. M. Keil, K. Umenhoffer, V. Kolisnychenko, B. Stahl, S. S. Sharma, M. de Arruda, V. Burland, S. W. Harcum and F. R. Blattner (2006). Emergent properties of reduced-genome Escherichia coli. Science 312: 1044-6.

Ranjit, D. K., G. W. Liechti and A. T. Maurelli (2020). Chlamydial MreB Directs Cell Division and Peptidoglycan Synthesis in Escherichia coli in the Absence of FtsZ Activity. mBio 11 
bioRxiv preprint doi: https://doi.org/10.1101/2021.11.08.467742; this version posted November 8, 2021. The copyright holder for this preprint (which was not certified by peer review) is the author/funder, who has granted bioRxiv a license to display the preprint in perpetuity. It is made available under aCC-BY 4.0 International license.

FtsA-FtsN antiparallel double filaments

Nierhaus 2021

Rohou, A. and N. Grigorieff (2015). CTFFIND4: Fast and accurate defocus estimation from electron micrographs. J Struct Biol 192: 216-21.

Russo, C. J., S. Scotcher and M. Kyte (2016). A precision cryostat design for manual and semi-automated cryo-plunge instruments. Rev Sci Instrum 87: 114302.

Salje, J., F. van den Ent, P. de Boer and J. Löwe (2011). Direct membrane binding by bacterial actin MreB. Mol Cell 43: 478-87.

Schoenemann, K. M., M. Krupka, V. W. Rowlett, S. L. Distelhorst, B. Hu and W. Margolin (2018). Gain-of-function variants of FtsA form diverse oligomeric structures on lipids and enhance FtsZ protofilament bundling. Mol Microbiol

Schuck, P. (2003). On the analysis of protein self-association by sedimentation velocity analytical ultracentrifugation. Anal Biochem 320: 104-24.

Sievers, F., A. Wilm, D. Dineen, T. J. Gibson, K. Karplus, W. Li, R. Lopez, H. McWilliam, M. Remmert, J. Soding, J. D. Thompson and D. G. Higgins (2011). Fast, scalable generation of high-quality protein multiple sequence alignments using Clustal Omega. Mol Syst Biol 7: 539.

Silva, J. C., R. Denny, C. A. Dorschel, M. Gorenstein, I. J. Kass, G. Z. Li, T. McKenna, M. J. Nold, K. Richardson, P. Young and S. Geromanos (2005). Quantitative proteomic analysis by accurate mass retention time pairs. Anal Chem 77: 2187200.

Sjodt, M., P. D. A. Rohs, M. S. A. Gilman, S. C. Erlandson, S. Zheng, A. G. Green, K. P. Brock, A. Taguchi, D. Kahne, S. Walker, D. S. Marks, D. Z. Rudner, T. G. Bernhardt and A. C. Kruse (2020). Structural coordination of polymerization and crosslinking by a SEDS-bPBP peptidoglycan synthase complex. Nat Microbiol

Squyres, G. R., M. J. Holmes, S. R. Barger, B. R. Pennycook, J. Ryan, V. T. Yan and E. C. Garner (2021). Single-molecule imaging reveals that Z-ring condensation is essential for cell division in Bacillus subtilis. Nat Microbiol 6: 553-562.

Szwedziak, P., Q. Wang, S. M. Freund and J. Löwe (2012). FtsA forms actin-like protofilaments. EMBO J 31: 2249-60. 
bioRxiv preprint doi: https://doi.org/10.1101/2021.11.08.467742; this version posted November 8,2021 . The copyright holder for this

preprint (which was not certified by peer review) is the author/funder, who has granted bioRxiv a license to display the preprint in perpetuity. It is made available under aCC-BY 4.0 International license.

FtsA-FtsN antiparallel double filaments

Nierhaus 2021

Szwedziak, P. and J. Löwe (2013). Do the divisome and elongasome share a common evolutionary past? Curr Opin Microbiol 16: 745-51.

Szwedziak, P., Q. Wang, T. A. Bharat, M. Tsim and J. Löwe (2014). Architecture of the ring formed by the tubulin homologue FtsZ in bacterial cell division. Elife 3: e04601.

Taguchi, A., M. A. Welsh, L. S. Marmont, W. Lee, M. Sjodt, A. C. Kruse, D. Kahne, T. G. Bernhardt and S. Walker (2019). FtsW is a peptidoglycan polymerase that is functional only in complex with its cognate penicillin-binding protein. Nat Microbiol 4: 587-594.

Tsang, M. J. and T. G. Bernhardt (2015). A role for the FtsQLB complex in cytokinetic ring activation revealed by an ftsL allele that accelerates division. Mol Microbiol 95: 925-44.

Turk, D. (2013). MAIN software for density averaging, model building, structure refinement and validation. Acta Crystallogr D Biol Crystallogr 69: 1342-57.

Typas, A., M. Banzhaf, C. A. Gross and W. Vollmer (2011). From the regulation of peptidoglycan synthesis to bacterial growth and morphology. Nat Rev Microbiol 10: 123-36.

van den Ent, F. and J. Löwe (2000). Crystal structure of the cell division protein FtsA from Thermotoga maritima. EMBO J 19: 5300-7.

van den Ent, F., L. A. Amos and J. Löwe (2001). Prokaryotic origin of the actin cytoskeleton. Nature 413: 39-44.

van den Ent, F., T. Izore, T. A. Bharat, C. M. Johnson and J. Löwe (2014). Bacterial actin MreB forms antiparallel double filaments. Elife 3: e02634.

Wagstaff, J. and J. Löwe (2018). Prokaryotic cytoskeletons: protein filaments organizing small cells. Nat Rev Microbiol 16: 187-201.

Wang, K., J. Fredens, S. F. Brunner, S. H. Kim, T. Chia and J. W. Chin (2016). Defining synonymous codon compression schemes by genome recoding. Nature 539: 5964. 
bioRxiv preprint doi: https://doi.org/10.1101/2021.11.08.467742; this version posted November 8, 2021. The copyright holder for this

preprint (which was not certified by peer review) is the author/funder, who has granted bioRxiv a license to display the preprint in perpetuity. It is made available under aCC-BY 4.0 International license.

FtsA-FtsN antiparallel double filaments

Nierhaus 2021

Whitley, K. D., C. Jukes, N. Tregidgo, E. Karinou, P. Almada, Y. Cesbron, R. Henriques, C. Dekker and S. Holden (2021). FtsZ treadmilling is essential for Zring condensation and septal constriction initiation in Bacillus subtilis cell division. Nat Commun 12: 2448.

Williams, C. J., J. J. Headd, N. W. Moriarty, M. G. Prisant, L. L. Videau, L. N. Deis, V. Verma, D. A. Keedy, B. J. Hintze, V. B. Chen, S. Jain, S. M. Lewis, W. B. Arendall, 3rd, J. Snoeyink, P. D. Adams, S. C. Lovell, J. S. Richardson and D. C. Richardson (2018). MolProbity: More and better reference data for improved allatom structure validation. Protein Sci 27: 293-315.

Winter, G., D. G. Waterman, J. M. Parkhurst, A. S. Brewster, R. J. Gildea, M. Gerstel, L. Fuentes-Montero, M. Vollmar, T. Michels-Clark, I. D. Young, N. K. Sauter and G. Evans (2018). DIALS: implementation and evaluation of a new integration package. Acta Crystallogr D Struct Biol 74: 85-97.

Wong, F., E. C. Garner and A. Amir (2019). Mechanics and dynamics of translocating MreB filaments on curved membranes. Elife 8

Yang, X., Z. Lyu, A. Miguel, R. McQuillen, K. C. Huang and J. Xiao (2017). GTPase activity-coupled treadmilling of the bacterial tubulin FtsZ organizes septal cell wall synthesis. Science 355: 744-747.

Yu, D., H. M. Ellis, E. C. Lee, N. A. Jenkins, N. G. Copeland and D. L. Court (2000). An efficient recombination system for chromosome engineering in Escherichia coli. Proc Natl Acad Sci U S A 97: 5978-83.

Zheng, S. Q., E. Palovcak, J. P. Armache, K. A. Verba, Y. Cheng and D. A. Agard (2017). MotionCor2: anisotropic correction of beam-induced motion for improved cryo-electron microscopy. Nat Methods 14: 331-332.

Zivanov, J., T. Nakane, B. O. Forsberg, D. Kimanius, W. J. Hagen, E. Lindahl and S. H. Scheres (2018). New tools for automated high-resolution cryo-EM structure determination in RELION-3. Elife 7 
bioRxiv preprint doi: https://doi.org/10.1101/2021.11.08.467742; this version posted November 8,2021 . The copyright holder for this preprint (which was not certified by peer review) is the author/funder, who has granted bioRxiv a license to display the preprint in perpetuity. It is made available under aCC-BY 4.0 International license.

FtsA-FtsN antiparallel double filaments

Nierhaus 2021

\section{ACKNOWLEDGEMENTS}

We thank D. Bellini, F. Gorrec and M. Yu (MRC LMB) for many helpful discussions on crystallisation and help with synchrotron data collection; the staff at Diamond Light Source beamlines 103 and I04 for excellent technical support; G. Cannone, C. Savva and all members of the LMB EM facility for training and support; G. Cannone and Y. Liu for help with EM data collection; T. Darling and J. Grimmett for help with computing infrastructure; K. Liu for WGS library preparation; all members of the Löwe group for discussions and technical help (all MRC LMB). T.N. was supported by a Boehringer Ingelheim Fonds (BIF) PhD fellowship and a Vice-Chancellor's Award by the Cambridge Commonwealth, European \& International Trust. F.B. was supported by an EMBO Advanced fellowship (ALTF 605-2019). This work was funded by the Medical Research Council (U105184326 to J.L.) and the Wellcome Trust (202754/Z/16/Z to J.L.). 
bioRxiv preprint doi: https://doi.org/10.1101/2021.11.08.467742. this version posted November 8,2021 . The copyright holder for this preprint (which was not certified by peer review) is the author/funder, who has granted bioRxiv a license to display the preprint in perpetuity. It is made available under aCC-BY 4.0 International license.

FtsA-FtsN antiparallel double filaments

Nierhaus 2021

\section{AUTHOR CONTRIBUTIONS}

T.N. performed protein purifications, electron microscopy, co-pelleting, in vivo cysteine cross-linking and strain characterisation. S.H.M. performed SPR, FP and FDS-AUC experiments. T.N., D.K.-C. and J.L. performed crystallisation and crystallography. S.M. and M.J.S. performed HDX-MS experiments. C.W.H.Y. and S.M.V.F. performed NMR experiments and assignments. L.F.H.F. designed the genome mutagenesis strategy under supervision of J.W.C., which was adapted by F.B. for combinatorial mutagenesis. T.N. and F.B. performed genome engineering. T.N. and L.F.H.F. performed next generation sequencing. J.L. supervised the study. T.N. and J.L. wrote the manuscript with contributions from all authors. 
bioRxiv preprint doi: https://doi.org/10.1101/2021.11.08.467742; this version posted November 8 , 2021. The copyright holder for this preprint (which was not certified by peer review) is the author/funder, who has granted bioRxiv a license to display the preprint in perpetuity. It is made available under aCC-BY 4.0 International license.

FtsA-FtsN antiparallel double filaments

Nierhaus 2021

\section{DATA AVAILABILITY}

Atomic coordinates have been deposited in the PDB with accession codes 7Q6D (Escherichia coli FtsA ${ }^{1-405}$ ), 7Q6G (Xenorhabdus poinarii FtsA $^{1-396}$ ), 7Q6F (Vibrio maritimus $\mathrm{FtsA}^{1-396}$, antiparallel double filament) and 7Q6I (Vibrio maritimus FtsA ${ }^{1-396}$ and $\mathrm{Fts}^{1-29}$, bent tetramers in antiparallel double filament arrangement). 
bioRxiv preprint doi: https://doi org/10.1101/2021 11.08.467742 this version posted November 8,2021 . The copyright holder for this preprint (which was not certified by peer review) is the author/funder, who has granted bioRxiv a license to display the preprint in perpetuity. It is made available under aCC-BY 4.0 International license.

FtsA-FtsN antiparallel double filaments

Nierhaus 2021

\section{FIGURES}

a

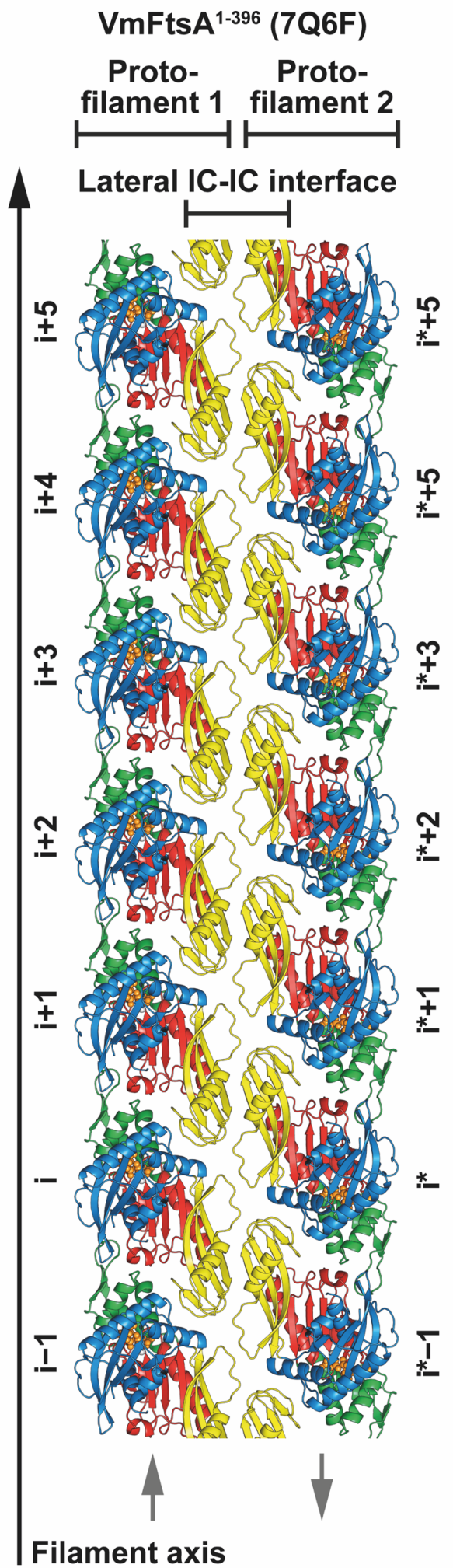

b

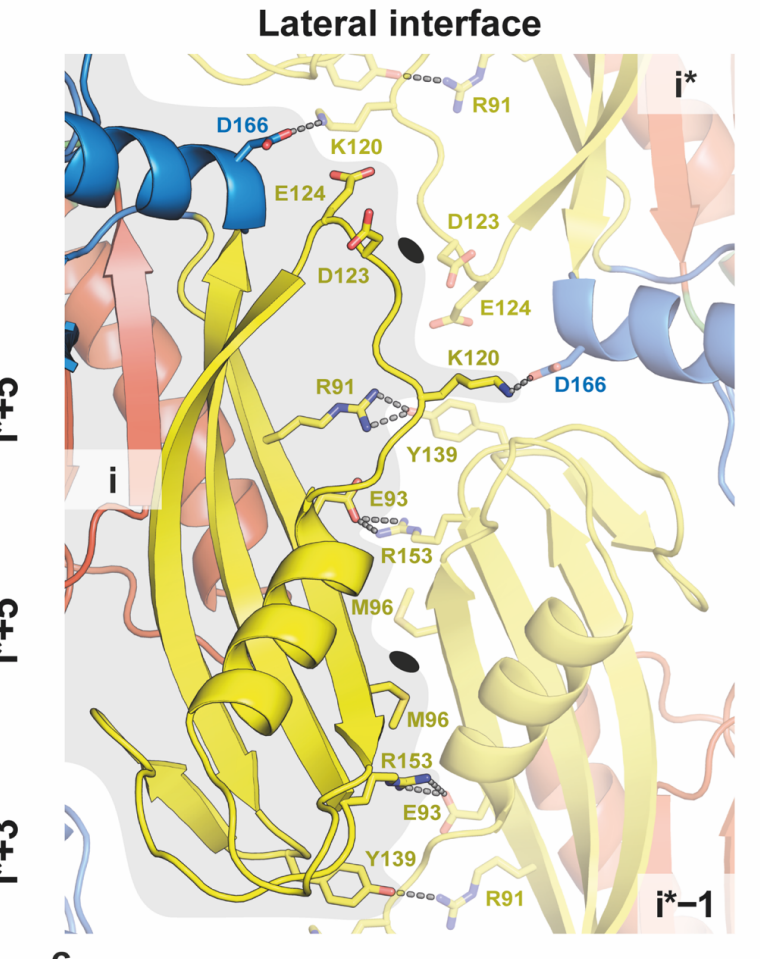

FtsA mutations

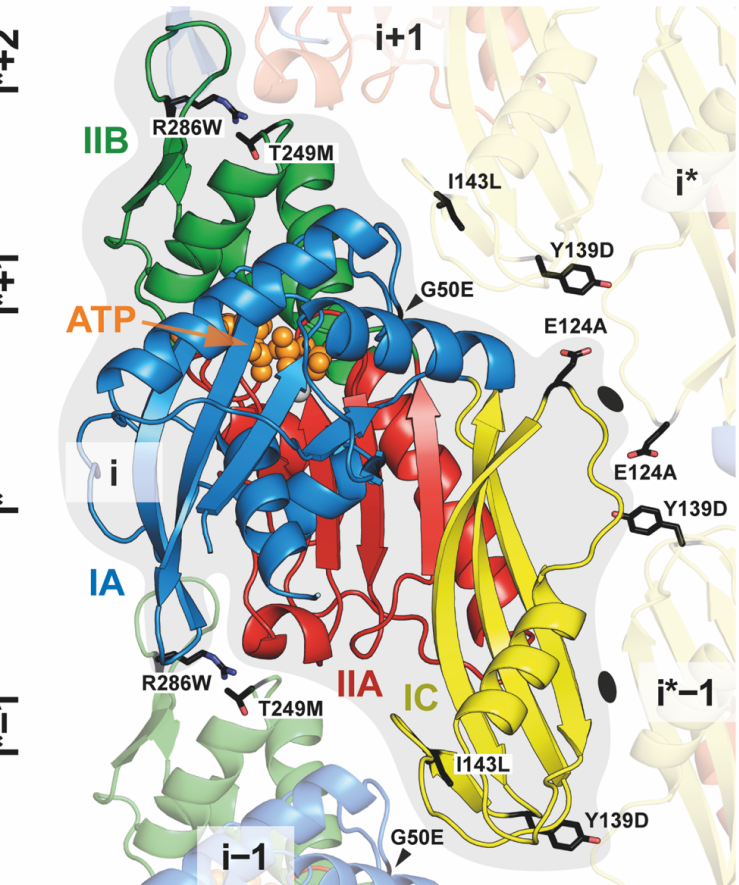

FtsN suppressor mutations: E124A, I143L

Mutations implied in FtsA filament architecture and ZipA suppression: G50E, Y139D, T249M, R286W 
bioRxiv preprint doi: https://doi.org/10.1101/2021.11.08.467742; this version posted November 8,2021 . The copyright holder for this preprint (which was not certified by peer review) is the author/funder, who has granted bioRxiv a license to display the preprint in perpetuity. It is made available under aCC-BY 4.0 International license.

FtsA-FtsN antiparallel double filaments

Nierhaus 2021

Figure 1. Vibrio maritimus FtsA crystallises as antiparallel double filaments via lateral contacts between IC domains.

a, Top view of the $\mathrm{VmFts} \mathrm{A}^{1-396}$ antiparallel double filament in cartoon representation from the membrane-proximal side (PDB 7Q6F). The lateral interface is almost exclusively formed by the IC domain (yellow). Grey arrows indicate the relative orientations of FtsA monomers in each protofilament. $\mathbf{b}$, Side chain interactions in the lateral filament interface. Each FtsA $A_{i}$ contacts two neighbouring FtsAs, Fts $A_{i-1^{*}}$ and Fts $A_{i^{*}}$, in the opposing protofilament. Both interfaces have local C2 symmetry (black ellipses). c, Reported FtsN suppressor mutations in E. coli FtsA, E124A (Bernard et al., 2007) and I143L (Liu et al., 2015), and ZipA suppressor mutations that recently have been implied in FtsA (double) filament formation (Schoenemann et al., 2018) are mapped on the VmFtsA double filament structure. All mutations are part of filament interfaces. 
bioRxiv preprint doi: https://doi.org/10.1101/2021.11.08.467742; this version posted November 8,2021 . The copyright holder for this preprint (which was not certified by peer review) is the author/funder, who has granted bioRxiv a license to display the preprint in perpetuity. It is made available under aCC-BY 4.0 International license.

a
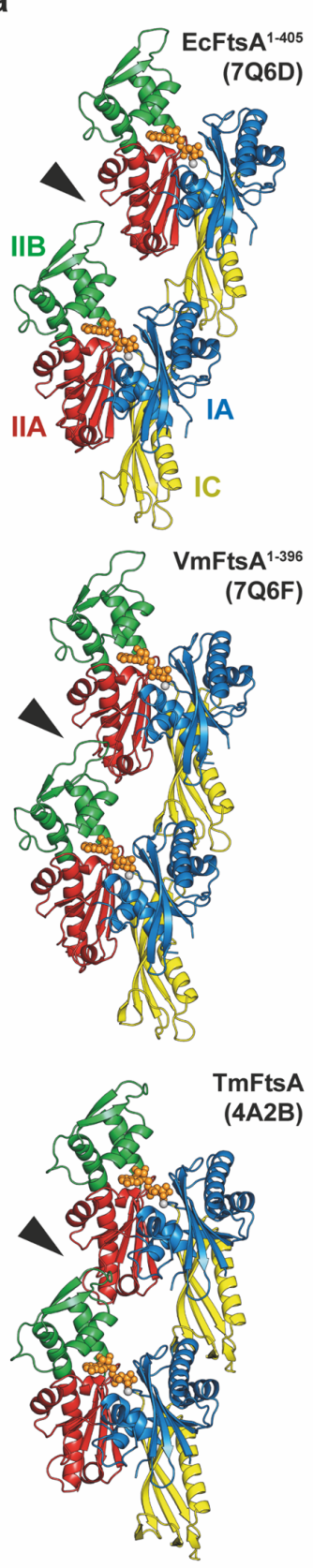

b
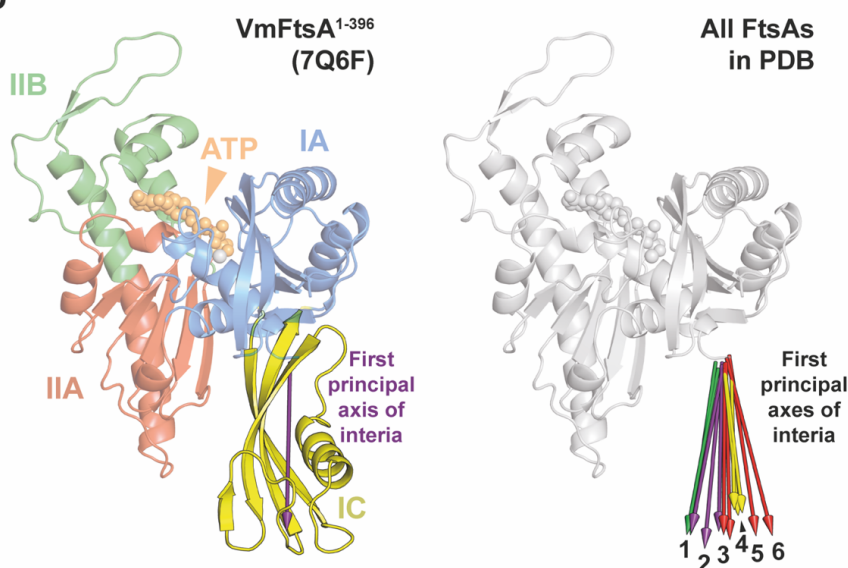

1: EcFtsA $A^{1.405}(7 Q 6 \mathrm{D}), \mathrm{XpFtsA}^{1.396}(7 \mathrm{QGG}), \mathrm{VmFtsA}^{1.396}+\mathrm{VmFtsN}^{1.29}$ (7Q61_A

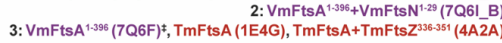
4: 6His-SaFtsA (3WT0), 6His-SaFsA (3WQU), GHis-SaFtsA (3WQT) 5: TmFtsA (4A2B)
6: TmFtsA (1E4F)

C
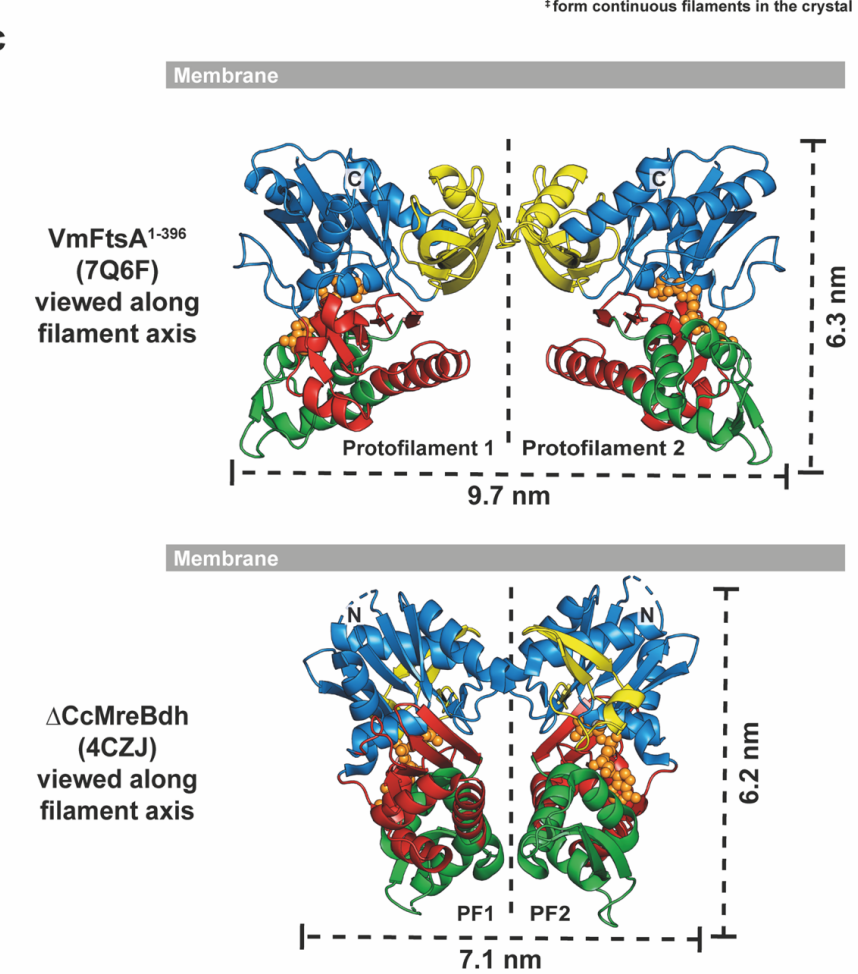
bioRxiv preprint doi: https://doi.org/10.1101/2021.11.08.467742; this version posted November 8 , 2021. The copyright holder for this preprint (which was not certified by peer review) is the author/funder, who has granted bioRxiv a license to display the preprint in perpetuity. It is made available under aCC-BY 4.0 International license.

FtsA-FtsN antiparallel double filaments

Nierhaus 2021

\section{Supplementary Figure S1.}

a, Comparison of longitudinal filament contacts in FtsA crystal structures from E. coli (PDB 7Q6D), V. maritimus (PDB 7Q6F) and T. maritima (PDB 4A2B). E. coli FtsA forms loose protofilaments with detached IIA and IIB domains (arrowhead). IIA and IIB domains are in close contact in the VmFtsA and TmFtsA structures, which form continuous filaments in the crystals. $\mathbf{b}$, The IC domain of FtsA is flexible. Left: an arrow along the first principal axis of inertia of the IC domain (purple) can be used to indicate IC domain orientation. Principal axes of inertia were calculated using main chain atoms (N, CA, C) of IC domains. Right: FtsA structures in the PDB aligned on their IA, IIA and IIB domains, with arrows indicating the position of the IC domains, showing that the IC domain orientation is variable within the FtsA monomer. There is no correlation between IC domain position and species (different colours) or formation of continuous filaments in the crystals $\left(^{\ddagger}\right)$. c, Comparison between the FtsA and MreB double filaments. Because the lateral interface is formed by the IC domain in the FtsA double filament, it is wider than the MreB double filament. The membrane-proximal side of both double filaments is flat. 
bioRxiv preprint doi: https://doi.org/10.1101/2021.11.08.467742; this version posted November 8, 2021. The copyright holder for this preprint (which was not certified by peer review) is the author/funder, who has granted bioRxiv a license to display the preprint in perpetuity. It is made available under aCC-BY 4.0 International license.

a

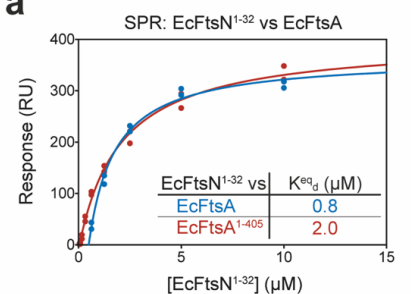

C

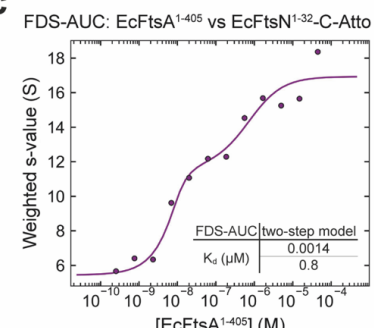

f
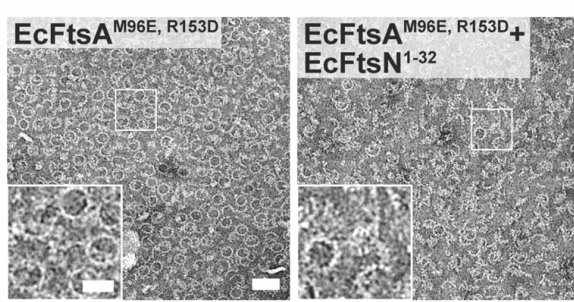

g

EcFtsA $(2.2 \mu \mathrm{M}) \quad$ FtsN suppressor mutations $(2.2 \mu \mathrm{M})$
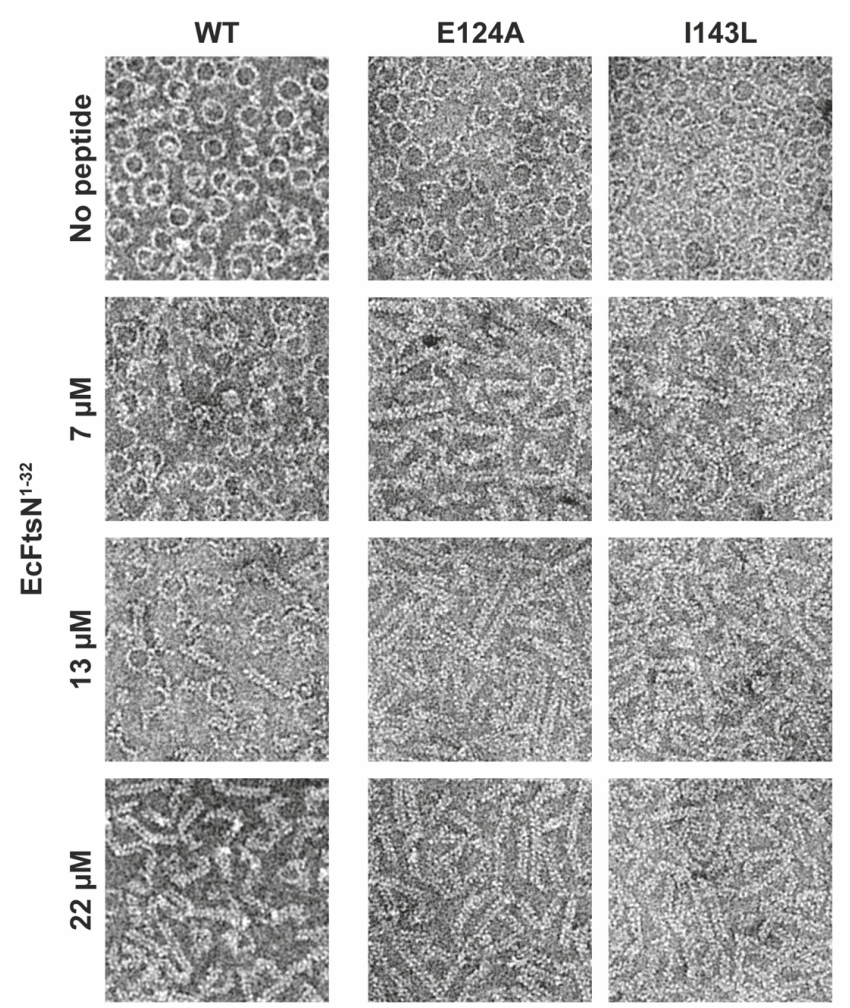

e
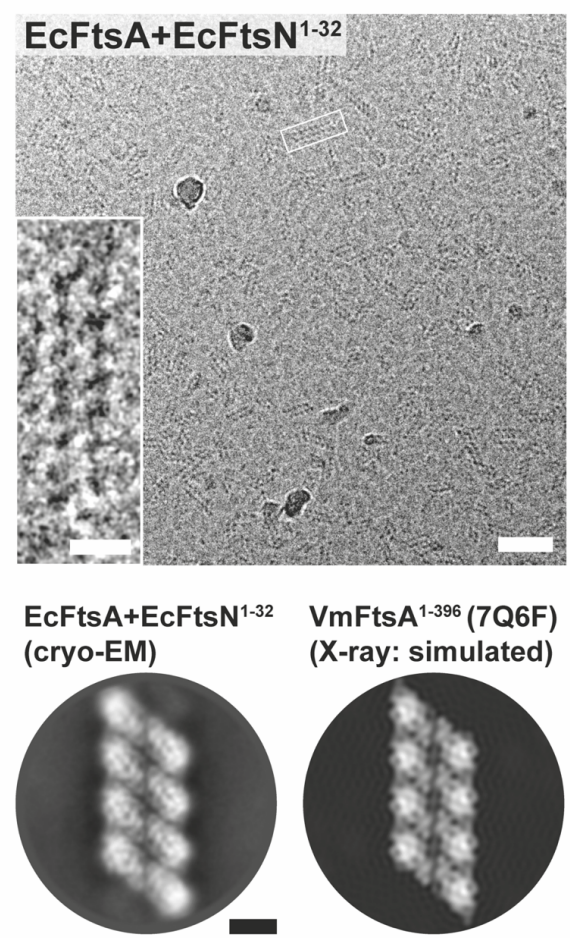

Filament architecture and ZipA suppressor mutations $(2.2 \mu \mathrm{M})$

G50E R286W/FtsA*
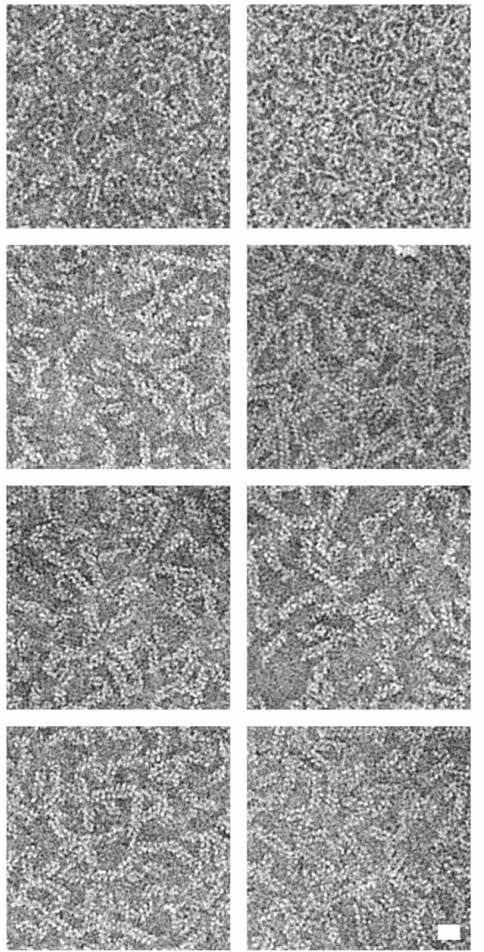
bioRxiv preprint doi: https://doi.org/10.1101/2021.11.08.467742; this version posted November 8, 2021. The copyright holder for this preprint (which was not certified by peer review) is the author/funder, who has granted bioRxiv a license to display the preprint in perpetuity. It is made available under aCC-BY 4.0 International license.

FtsA-FtsN antiparallel double filaments

Nierhaus 2021

Figure 2: E. coli FtsA forms antiparallel double filaments upon binding the cytoplasmic tail of FtsN, EcFtsN ${ }^{1-32}$.

a, SPR equilibrium response titration of $\mathrm{EcFtsN}^{1-32}$ binding to immobilised EcFtsA (blue) or EcFtsA lacking its C-terminal membrane binding helix, EcFtsA ${ }^{1-405}$ (red). EcFtsN ${ }^{1-32}$ has micromolar affinity for both FtsA proteins. b, EcFtsA ${ }^{1-405}$ titration into fluorescently labelled EcFtsN ${ }^{1-32}$-Cys-Atto 495. Data were fitted with a two-step model, with transitions being indicative of FtsN binding and polymerisation (panel c). $\mathrm{K}_{d} \mathrm{~S}$ are given as mean \pm SEM. C, Change in the weight-averaged sedimentation coefficient of a EcFtsA ${ }^{1-405}$ titration into fluorescently labelled EcFtsN ${ }^{1-32}-C y s-A t t o 495$ by fluorescence detection system (FDS)-AUC shows that EcFtsN ${ }^{1-32}$ is part of higher order FtsA polymers. Data were fitted to a two-step model, recapitulating the FP data in panel b. $\mathbf{d}$, Co-pelleting assay of EcFtsN $\mathrm{N}^{1-32}$ titrated into EcFts $\mathrm{A}^{1-405}$. The fraction of FtsA in the pellet (orange) increases with increasing amounts of $\mathrm{EcFtsN}^{1-32}$, indicating that $\mathrm{EcFtsN}^{1-32}$ induces FtsA polymerisation. Given are mean \pm sd (black lines) of technical duplicates. e, EcFtsA and EcFtsN ${ }^{1-32}$ form double filaments on supported lipid monolayers as determined by cryo-EM. 2D classification confirmed the antiparallel arrangement of the observed double filaments. A computed 2D projection from the VmFtsA double filament crystal structure (PDB 7Q6F) is shown for comparison. Scale bars, $50 \mathrm{~nm}, 10 \mathrm{~nm}$ (inset), $5 \mathrm{~nm}$ (2D class averages). f, Based on the VmFtsA crystal structure (PDB 7Q6F), a lateral interface mutant of E. coli FtsA, EcFtsA ${ }^{M 96 E}$, R153D, was designed. EcFtsA $A^{M 96 E, ~ R 153 D ~ i s ~ d e f i c i e n t ~ i n ~ F t s N ~}{ }^{1-32}$-dependent double filament formation as determined by negative stain electron microscopy on a supported lipid monolayer. Scale bar, $50 \mathrm{~nm}, 20 \mathrm{~nm}$ (inset). g, Negative stain electron micrographs of EcFtsA and EcFtsA mutants on supported lipid monolayers with increasing concentrations of EcFtsN ${ }^{1-32}$. EcFtsA forms "mini-rings" in the absence of 
bioRxiv preprint doi: https://doi.org/10.1101/2021.11.08.467742; this version posted November 8,2021 . The copyright holder for this preprint (which was not certified by peer review) is the author/funder, who has granted bioRxiv a license to display the preprint in perpetuity. It is made available under aCC-BY 4.0 International license.

FtsA-FtsN antiparallel double filaments

Nierhaus 2021

FtsN peptide, as described previously (Krupka et al., 2017). With increasing EcFtsN ${ }^{1-}$ 32 concentrations, EcFtsA forms fewer "mini-rings" and more double filaments, until only double filaments are present at ten-fold molar excess of EcFtsN ${ }^{1-32}$. The FtsN suppressor mutants $\mathrm{Fts} \mathrm{A}^{\mathrm{E} 124 \mathrm{~A}}$ and $\mathrm{Fts} \mathrm{A}^{1143 \mathrm{~L}}$ more readily form double filaments at lower EcFtsN ${ }^{1-32}$ concentrations than wildtype FtsA. Introduction of the G50E or R286W mutations into EcFtsA decreases the number of "mini-rings" formed in the absence of EcFtsN ${ }^{1-32}$. Both mutations also facilitate FtsA double filament formation at lower concentrations of EcFtsN ${ }^{1-32}$, compared to wildtype. See Figure 1c for the position of the mutations in the double FtsA filament. Scale bar, $20 \mathrm{~nm}$. 
bioRxiv preprint doi: https://doi.org/10.1101/2021.11 08.467742; this version posted November 8,2021 . The copyright holder for this preprint (which was not certified by peer review) is the author/funder, who has granted bioRxiv a license to display the preprint in perpetuity. It is made available under aCC-BY 4.0 International license.

a

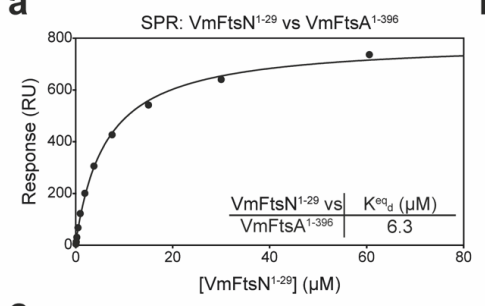

C

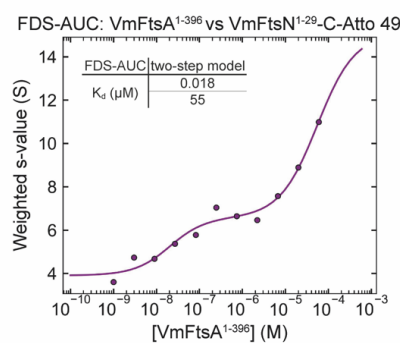

g

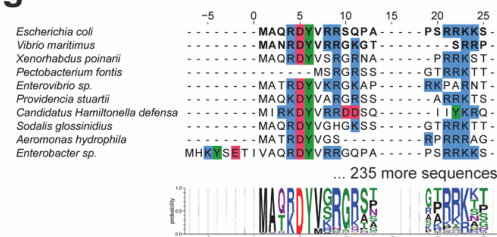

f

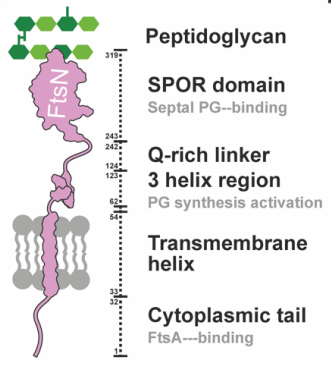

h
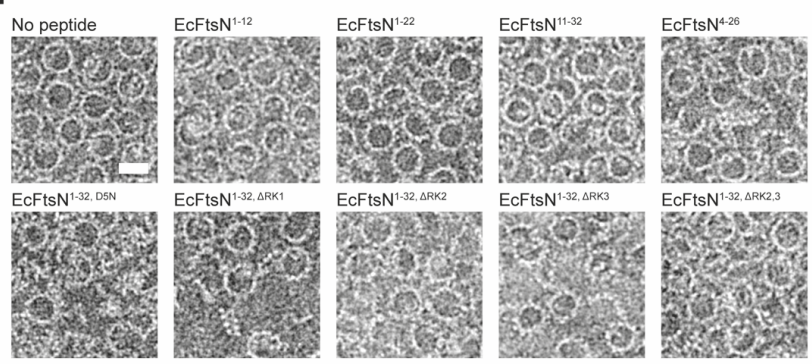

EcFtsN'132

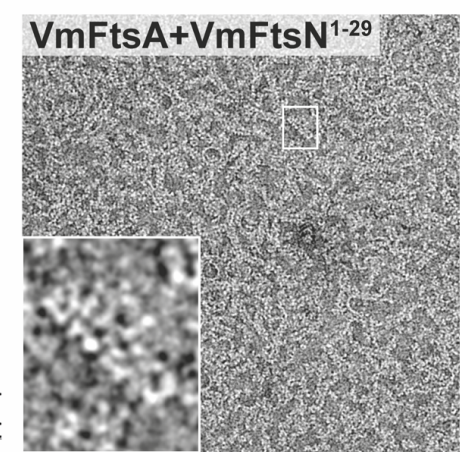

i

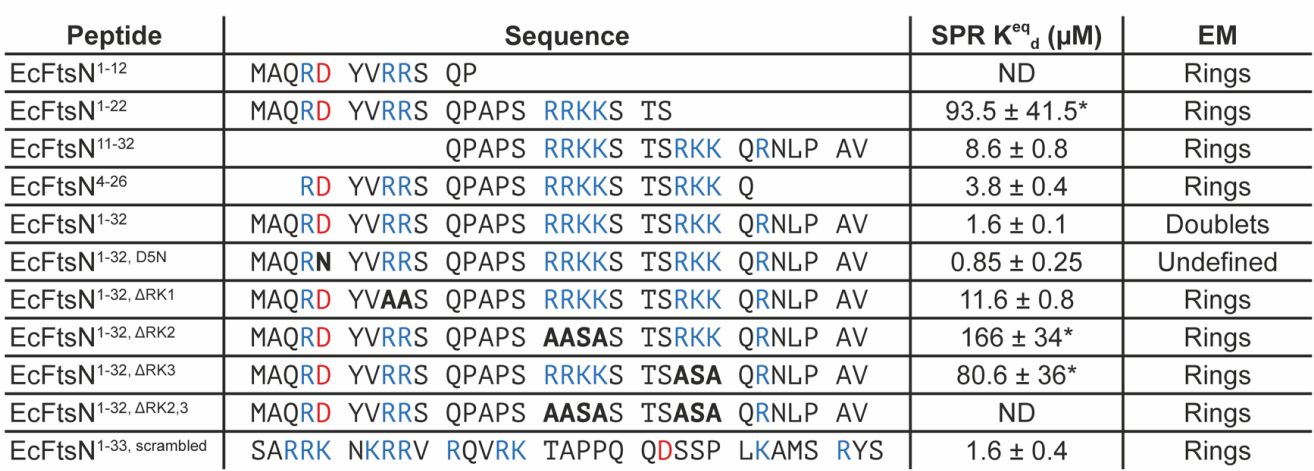


bioRxiv preprint doi: https://doi.org/10.1101/2021.11.08.467742; this version posted November 8,2021 . The copyright holder for this preprint (which was not certified by peer review) is the author/funder, who has granted bioRxiv a license to display the preprint in perpetuity. It is made available under aCC-BY 4.0 International license.

FtsA-FtsN antiparallel double filaments

Nierhaus 2021

\section{Supplementary Figure S2.}

a, SPR equilibrium response titration of $\mathrm{VmFtsN}^{1-29}$ binding to immobilised $\mathrm{VmFts} \mathrm{A}^{1-}$ 396. Binding affinity is about three-fold lower than for the EcFtsA $\mathrm{A}^{1-405}-\mathrm{EcFts} \mathrm{N}^{1-32}$ interaction (Figure 2a). b, VmFtsA $\mathrm{A}^{1-396}$ titration into fluorescently labelled $\mathrm{VmFtsN}^{1-29}$ C-Atto 495. Data were fitted with a two-step model with transitions being indicative of FtsN binding and polymerisation (panel c). $\mathrm{K}_{d} \mathrm{~S}$ are given as mean $\pm \mathrm{SEM}$. c, Change in the weight-averaged sedimentation coefficient of a VmFtsA ${ }^{1-396}$ titration into fluorescently labelled $\mathrm{VmFtsN}^{1-29}-\mathrm{C}-\mathrm{Atto} 495$ by FDS-AUC shows that $\mathrm{VmFtsN}^{1-29}$ is part of higher order FtsA polymers. Data were fitted to a two-step model, recapitulating the FP data in panel b. $\mathbf{d}$, Co-pelleting assay of $\mathrm{VmFts}^{1-29}$ titrated into $\mathrm{VmFtsA}^{1-396}$. The fraction of FtsA in the pellet (orange) increases with increasing amounts of $\mathrm{VmFtsN}^{1-29}$, indicating that $\mathrm{VmFts}^{1-29}$ induces polymerisation of $\mathrm{VmFtsA}$. Given are mean \pm sd (black lines) of technical duplicates. e, Negative stain electron micrographs of $\mathrm{VmFtsA}$ with and without $\mathrm{VmFtsN}^{1-29}$ on supported lipid monolayers. Similar to E. coli FtsA, V. maritimus FtsA forms "mini-rings" in the absence of FtsN and double filaments at ten-fold molar excess of $\mathrm{VmFtsN}^{1-29}$. Scale bar, $50 \mathrm{~nm}, 20 \mathrm{~nm}$ (inset). $\mathbf{f}$, Schematic overview of EcFtsN, illustrating domain boundaries. g, Multiple sequence alignment of $245 \mathrm{FtsN}$ sequences comprising cytoplasmic and transmembrane domains. Ten exemplary sequences are shown including Fts $N$ sequences from the organisms used in this study, namely E. coli, V. maritimus and X.poinarii. The sequences of EcFtsN $\mathrm{N}^{1-32}$ and $\mathrm{VmFtsN}^{1-29}$ are highlighted in bold. $\mathbf{h}$, Mapping of the FtsA-interacting region in $\mathrm{EcFtsN}^{1-32}$ using the lipid monolayer assay. EcFts $\mathrm{N}^{1-32}$ truncations and mutants were in ten-fold molar excess of FtsA. In contrast to EcFtsN ${ }^{1-}$ 32, EcFtsN ${ }^{1-32, \text { D5N }}$ did not facilitate FtsA double filament formation. EcFtsN ${ }^{4-26}$ and

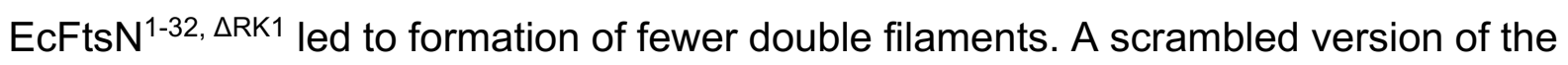


bioRxiv preprint doi: https://doi.org/10.1101/2021.11.08.467742; this version posted November 8,2021 . The copyright holder for this preprint (which was not certified by peer review) is the author/funder, who has granted bioRxiv a license to display the preprint in perpetuity. It is made available under aCC-BY 4.0 International license.

FtsA-FtsN antiparallel double filaments

Nierhaus 2021

FtsN peptide (Baranova et al., 2020) did not induce double filaments. Scale bar, 20 $\mathrm{nm}$. i, Summary of EcFtsN ${ }^{1-32}$ peptides. Mutations are highlighted in bold. Equilibrium dissociation constants $\left(\mathrm{K}^{\mathrm{eq}} \mathrm{d}\right)$ are given for SPR experiments as mean \pm SEM $(\mathrm{n} \geq 2$ for each construct). For weak binders the maximum response was fixed during fitting, hence these are only approximate values as indicated by asterisks. "ND", not determinable. The predominant higher order polymer observed in the monolayer assay is given in the "EM" column. Note that $\mathrm{EcFtsN}^{4-26}$ and EcFtsN"1-32, $\Delta \mathrm{RK} 1$ still lead to formation of a few FtsA double filaments. EcFtsN ${ }^{1-33}$, scrambled matches a previously described version bearing an additional $\mathrm{N}$-terminal cysteine and a C-terminal hexahistidine tag, which were removed for this study (Baranova et al., 2020). 
bioRxiv preprint doi: https://doi org/10.1101/2021.11.08.467742· this version posted November 8,2021 . The copyright holder for this preprint (which was not certified by peer review) is the author/funder, who has granted bioRxiv a license to display the preprint in perpetuity. It is made available under aCC-BY 4.0 International license.

a

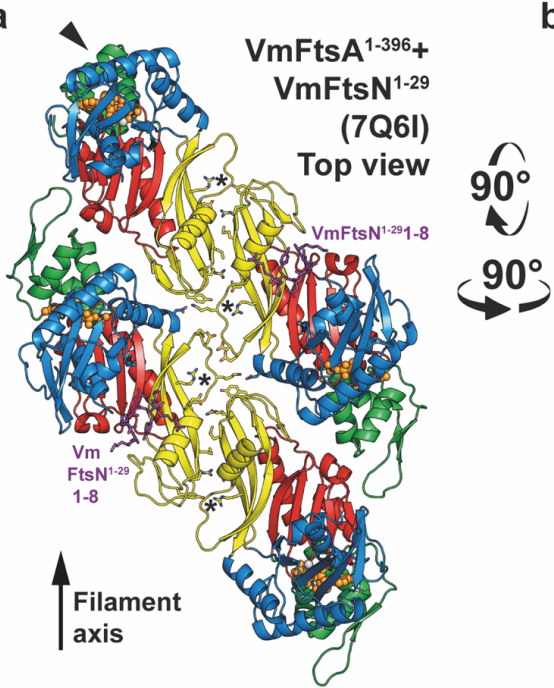

C

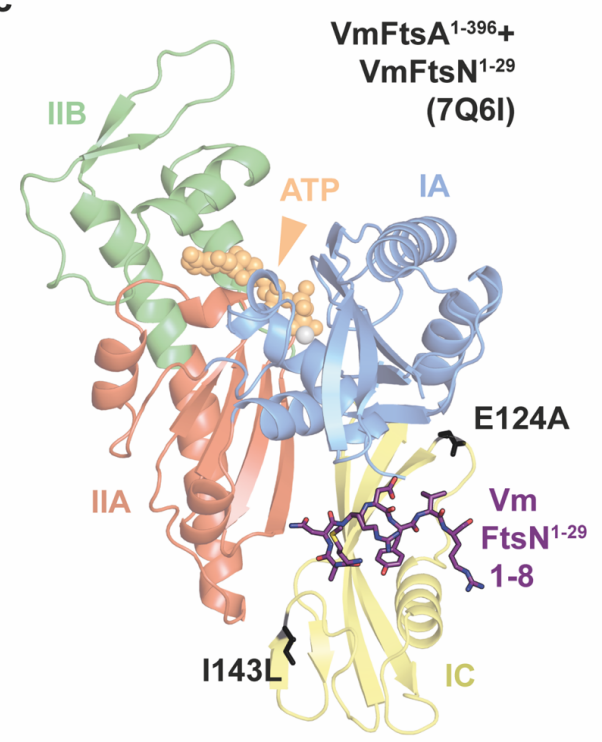

b

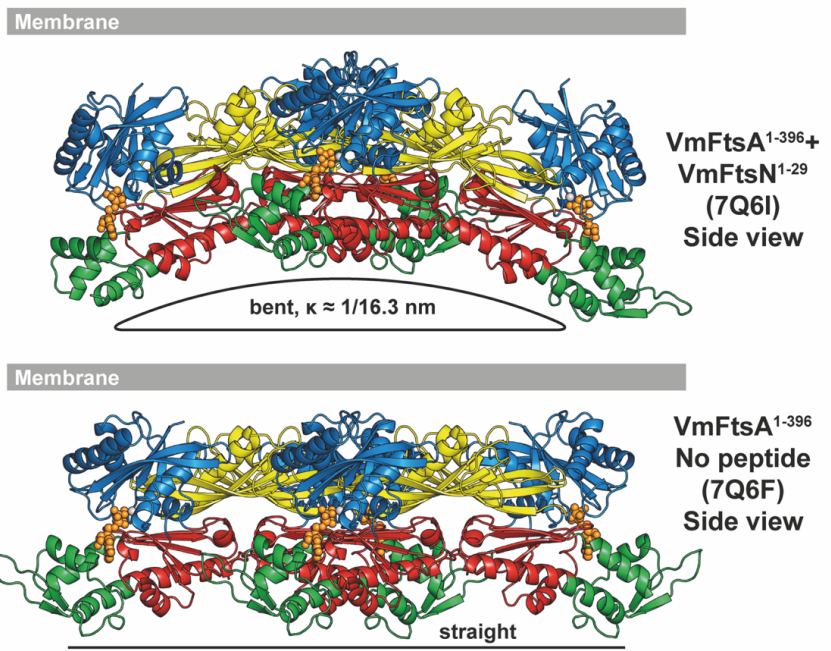

d
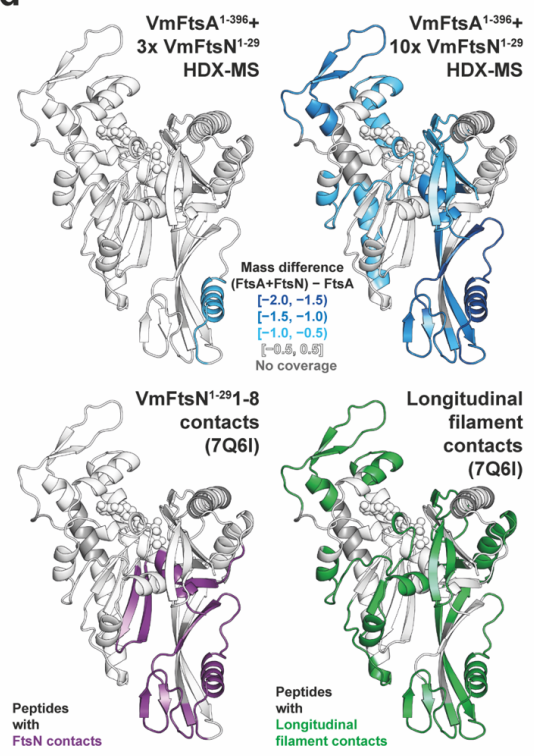

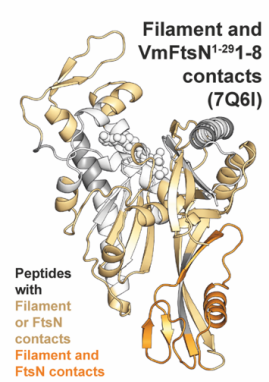

(2)

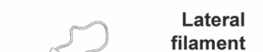


bioRxiv preprint doi: https://doi.org/10.1101/2021.11.08.467742; this version posted November 8,2021 . The copyright holder for this preprint (which was not certified by peer review) is the author/funder, who has granted bioRxiv a license to display the preprint in perpetuity. It is made available under aCC-BY 4.0 International license.

FtsA-FtsN antiparallel double filaments

Nierhaus 2021

Figure 3. VmFtsA ${ }^{1-396}$ and $\mathrm{VmFts}^{1-29}$ co-crystallise as short, bent double filaments, with VmFts ${ }^{1-29}$ binding FtsA in the IA-IC interdomain cleft.

a, 16 FtsA monomers in the ASU of the co-crystal structure are organised into short, antiparallel, and curved tetramers. Top view of a representative tetramer (which requires crystal symmetry to be applied to the PDB coordinates) from the membraneproximal side. Residues 1-8 of $\mathrm{VmFtsN}^{1-29}$ (purple sticks) are present in the closed subunit of each protofilament. IC domains are tilted against each other compared to the VmFtsA ${ }^{1-396}$ double filament structure (PDB 7Q6F), presumably destabilising the R91-Y139 interaction (asterisks) in the lateral interface. The IIB domain of the top left monomer (chain D) is partially disordered (arrowhead). b, A comparison of the side views of the PDB 7Q6I and PDB 7Q6F crystal structures illustrates that the 7Q6I tetramer is bent along the filament axis. c, Residues 1-8 of $\mathrm{VmFtsN}^{1-29}$ bind in the IAIC interdomain cleft of $\mathrm{VmFts} \mathrm{A}^{1-396}$. Positions of FtsN suppressor mutations $\mathrm{E} 124 \mathrm{~A}$ (Bernard et al., 2007) and I143L (Liu et al., 2015) are shown in black. d, HDX-MS analysis of $\mathrm{VmFtsA} \mathrm{A}^{1-396}$ with three- $(30 \mu \mathrm{M})$ or ten-fold molar excess $(100 \mu \mathrm{M})$ of VmFtsN ${ }^{1-29}$, confirming $V m F t s N^{1-29}$ to bind in the IA-IC interdomain cleft of FtsA. Peptides that are protected in the presence of $\mathrm{VmFtsN}^{1-29}$ (slower exchange of hydrogen for deuterium) are highlighted in blue. Presumably because high concentrations of $\mathrm{VmFtsN}^{1-29}$ induce polymerisation of $\mathrm{VmFtsA}^{1-396}$ (Supplementary Figure S2c, d), peptides mapping to the filament interfaces are protected as well. For orientation, peptides are coloured according to their involvement in different interfaces of the VmFtsA ${ }^{1-396}-V_{m F t s N}{ }^{1-29}$ co-polymer (PDB 7Q6I). 
bioRxiv preprint doi: https:/doi.org/10.1101/2021.11.08.467742; this version posted November 8, 2021. The copyright holder for this preprint (which was not certified by peer review) is the author/funder, who has granted bioRxiv a license to display the preprint in perpetuity. It is made available under aCC-BY 4.0 International license.

a

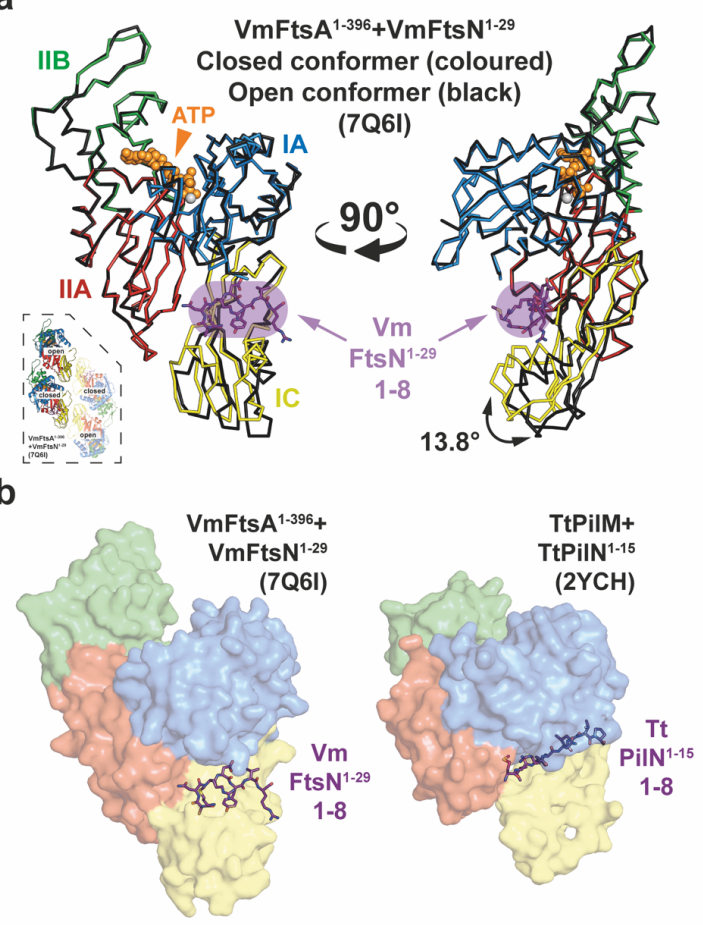

C

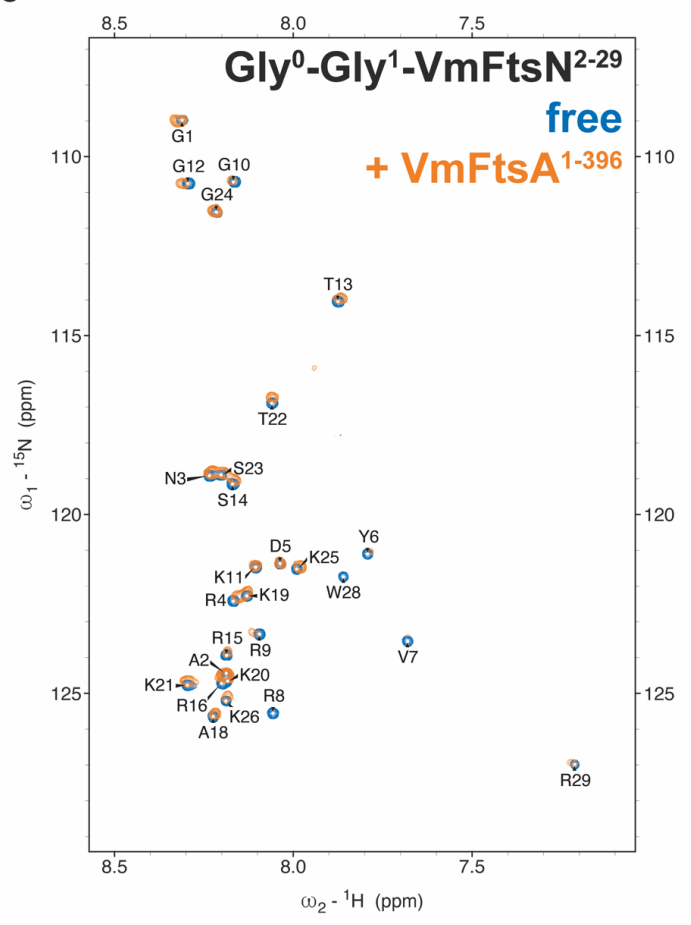

d

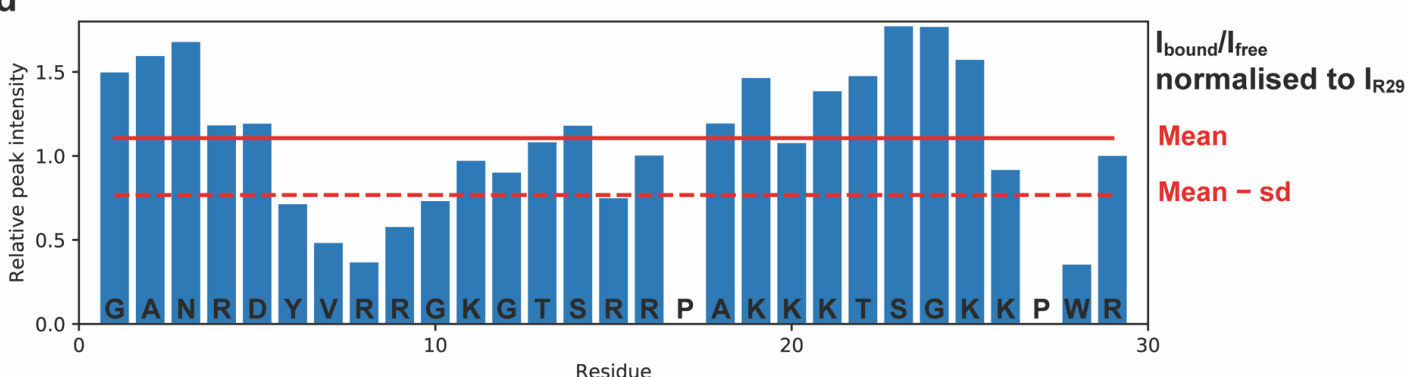

e

VmFtsA $A^{1-396}+\mathrm{VmFtsN}^{1-29}(7 \mathrm{Q} 6 \mathrm{l})$ Density-guided VmFtsN $\mathrm{N}^{1-29}$ modelling: M1-R8
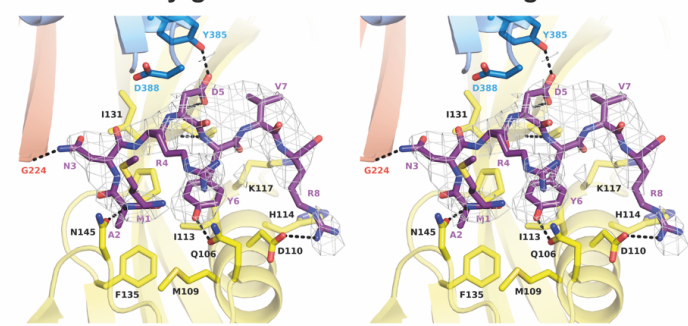

VmFtsA $A^{1-396}+\mathrm{VmFts}^{1-29}$ (7Q6I) NMR-guided VmFts N1-29 modelling: Y6-K11

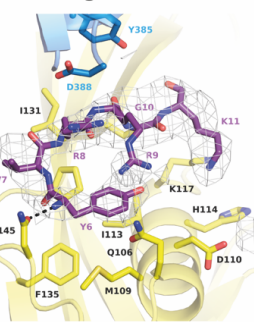


bioRxiv preprint doi: https://doi.org/10.1101/2021.11.08.467742; this version posted November 8, 2021. The copyright holder for this preprint (which was not certified by peer review) is the author/funder, who has granted bioRxiv a license to display the preprint in perpetuity. It is made available under aCC-BY 4.0 International license.

FtsA-FtsN antiparallel double filaments

Nierhaus 2021

\section{Supplementary Figure S3.}

a, Comparison between the peptide-bound closed (coloured) and peptide-free open conformer (black) of FtsA in the $\mathrm{VmFtsA}{ }^{1-396}-\mathrm{VmFtsN}^{1-29}$ co-crystal structure (PDB 7Q6I). The IC domain of the open conformer is rotated $13.8^{\circ}$ downwards compared to the closed conformer, as determined by analysis with DynDom (Hayward and Lee, 2002). Consequently, the open conformation is likely incompatible with $\mathrm{VmFts} \mathrm{N}^{1-29}$ binding. The inset shows the position of open and closed conformers within the tetramer. b, Comparison between the V. maritimus FtsA-FtsN and Thermus thermophilus PilM-PiIN (PDB 2YCH) interaction sites (Karuppiah and Derrick, 2011). While both binding sites are in the IA-IC interdomain cleft of FtsA and PilM, they occupy distinct subspaces. FtsN predominantly contacts the IC domain of FtsA, whereas PilN binds closer to the IA domain of PilM. c, ${ }^{1} \mathrm{H},{ }^{15} \mathrm{~N} 2 \mathrm{D}-\mathrm{HSQC}$ NMR spectrum of free Gly-Gly-VmFtsN ${ }^{2-29}$ (blue) and with equimolar amounts of FtsA added (orange). To follow VmFtsN numbering, the first glycine of Gly-Gly-VmFtsN ${ }^{2-29}$ is assigned as G0. d, Changes in relative peak intensity expressed as $I_{\text {bound }} / I_{\text {free }}$ with intensities normalised to $I_{R 29}$, which is assumed not to be involved in the VmFtsA-FtsN interaction. e, Stereo images of the FtsA-FtsN interaction site in the VmFtsA ${ }^{1-396}$ VmFtsN ${ }^{1-29}$ co-crystal structure (PDB 7Q6I). Left: our preferred interpretation of the electron density corresponding to $\mathrm{VmFtsN}^{1-29}$, with residues M1-R8 modelled (purple) and electron density map (grey) shown at 1.2 sigma. Side chains of FtsA residues in the interaction site are shown as sticks and polar contacts are marked with black, dashed lines. Right: electron density interpretation guided by the NMR data instead (panels $\mathrm{c}$ and $\mathrm{d}$ ), with residues $\mathrm{Y} 6-\mathrm{K} 11$ of $\mathrm{VmFtsN}^{1-29}$ modelled (purple). Electron density map (grey) is shown at 1.2 sigma. 
bioRxiv preprint doi: https://doi org/10.1101/2021.11.08.467742 this version posted November 8 2021. The copyright holder for this preprint (which was not certified by peer review) is the author/funder, who has granted bioRxiv a license to display the preprint in perpetuity. It is made available under aCC-BY 4.0 International license.

FtsA-FtsN antiparallel double filaments

Nierhaus 2021

a

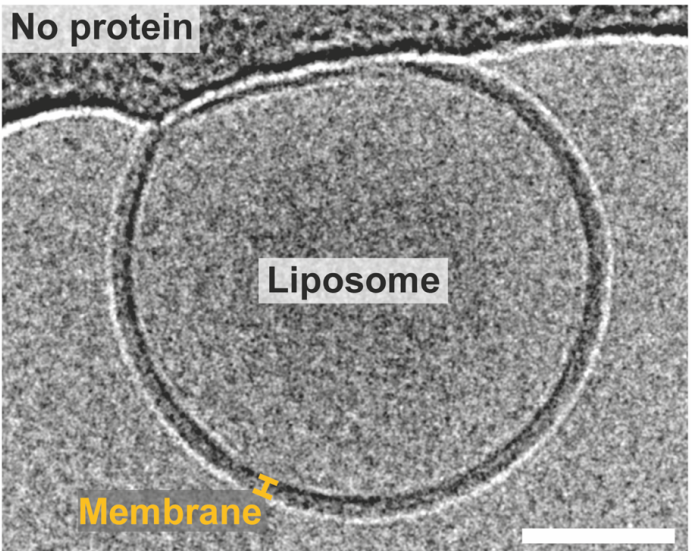

b
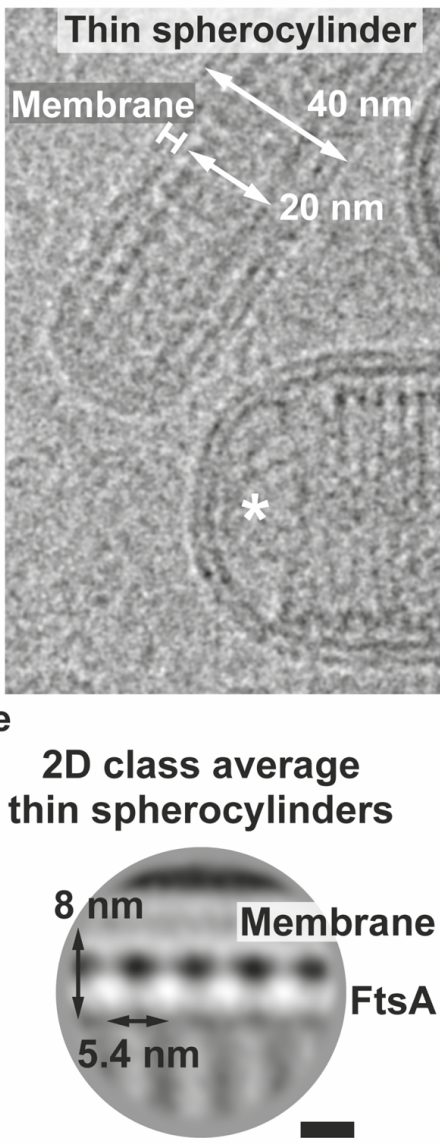
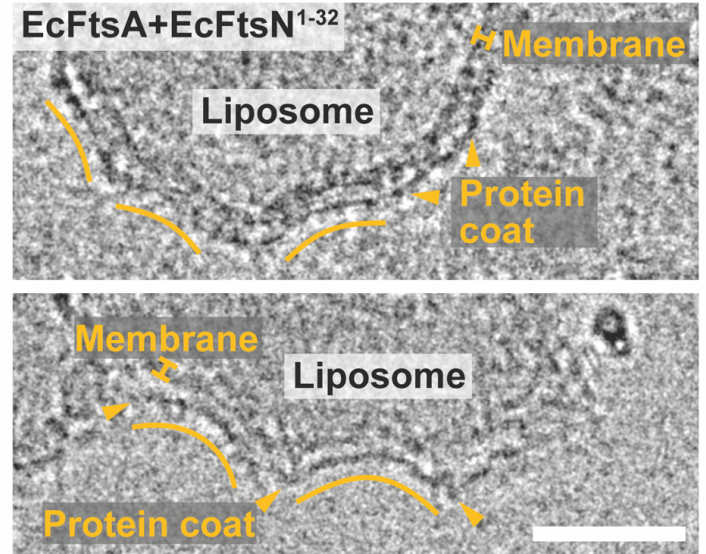

C

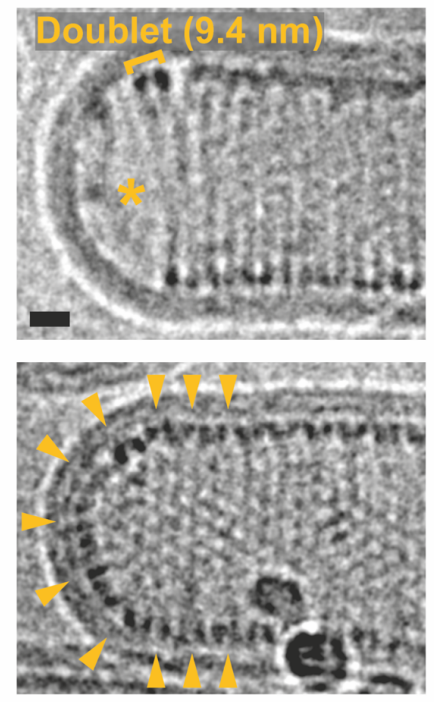

d

2D class average thick spherocylinders

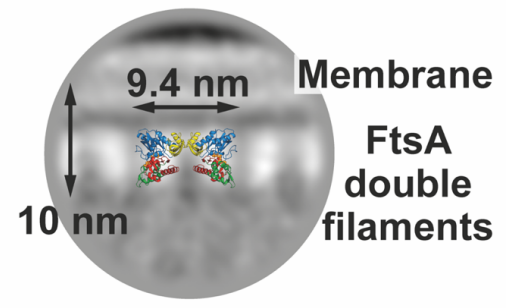

7Q6F structure to scale

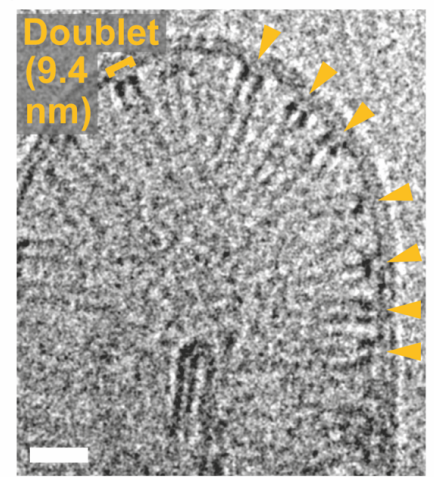


bioRxiv preprint doi: https://doi.org/10.1101/2021.11.08.467742; this version posted November 8, 2021. The copyright holder for this preprint (which was not certified by peer review) is the author/funder, who has granted bioRxiv a license to display the preprint in perpetuity. It is made available under aCC-BY 4.0 International license.

FtsA-FtsN antiparallel double filaments

Nierhaus 2021

Figure 4. EcFtsA-Fts $\mathrm{N}^{1-32}$ double filaments assembled on and in liposomes show a preference for negative Gaussian curvature.

a, Right: cryo-EM micrograph showing a spherical liposome with no proteins added. The carbon edge of the grid is visible at the top of the image. Left: cryo-EM micrographs of liposomes with EcFtsA-FtsN ${ }^{1-32}$ filaments (arrowheads) bound to the outside. Liposomes show indentations with negative Gaussian curvature. See Salje et al. for a comparison with MreB filaments added to liposomes (Salje et al., 2011). Scale bars, $50 \mathrm{~nm}$. b, Encapsulation of EcFtsA and $\mathrm{EcFtsN}^{1-32}$ proteins in liposomes produces thin and thick protein-filled spherocylinders (rods) with diameters of $\sim 40 \mathrm{~nm}$ and $\sim 70 \mathrm{~nm}$, respectively. EcFtsA-FtsN ${ }^{1-32}$ filaments are aligned with the short axis of the spherocylinders. Note that there are no filaments in the hemisphere of a thick spherocylinder (asterisk). See Hussain et al. for a comparison with MreB filaments encapsulated into liposomes (Hussain et al., 2018). Scale bar, $20 \mathrm{~nm}$. c, Cryo-EM micrographs of EcFtsA-FtsN ${ }^{1-32}$ double filaments in thick spherocylinders. Top: Thick spherocylinders are filled with EcFtsA-FtsN ${ }^{1-32}$ double filaments that are aligned with the short axis. Note that there are no filaments in the hemisphere of the spherocylinder (asterisk). Bottom: EcFtsA-FtsN ${ }^{1-32}$ double filaments are aligned with the short axis in the cylindrical part of the spherocylinder but are randomly oriented in the hemisphere (arrowheads). Scale bar, $10 \mathrm{~nm}$. d, Liposome with few EcFtsA-FtsN ${ }^{1-32}$ double filaments inside. EcFtsA-FtsN ${ }^{1-32}$ double filaments are randomly oriented in the semicircular part of the liposome but are more aligned in the cylindrical part (arrowheads). Scale bar, $20 \mathrm{~nm}$. e, 2D class averages of FtsA membrane attachment sites in thin and thick spherocylinders. EcFtsA-FtsN ${ }^{1-32}$ are organised into single protofilaments in thin spherocylinders, possibly due to lower amounts of EcFtsN $\mathrm{N}^{1-32}$ being entrapped in these liposomes. Thick spherocylinders contain EcFtsA-Fts $\mathrm{N}^{1-32}$ double filaments. End 
bioRxiv preprint doi: https://doi.org/10.1101/2021.11.08.467742; this version posted November 8, 2021. The copyright holder for this preprint (which was not certified by peer review) is the author/funder, who has granted bioRxiv a license to display the preprint in perpetuity. It is made available under aCC-BY 4.0 International license.

FtsA-FtsN antiparallel double filaments

Nierhaus 2021

view of the VmFtsA ${ }^{1-396}$ double filament structure (PDB 7Q6F) shown to scale. Scale bar, $5 \mathrm{~nm}$. 
bioRxiv preprint doi: https://doi org/10.1101/2021 11.08.467742· this version posted November 8,2021 . The copyright holder for this preprint (which was not certified by peer review) is the author/funder, who has granted bioRxiv a license to display the preprint in perpetuity. It is made available under aCC-BY 4.0 International license.

FtsA-FtsN antiparallel double filaments

Nierhaus 2021

a

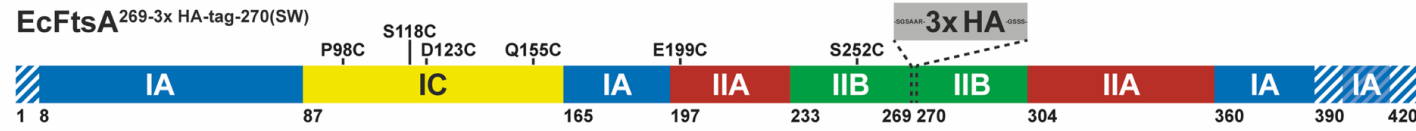

b

d

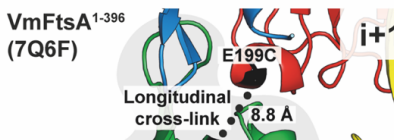

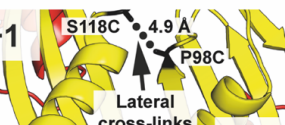
Pogc Lass-links $i^{*}$
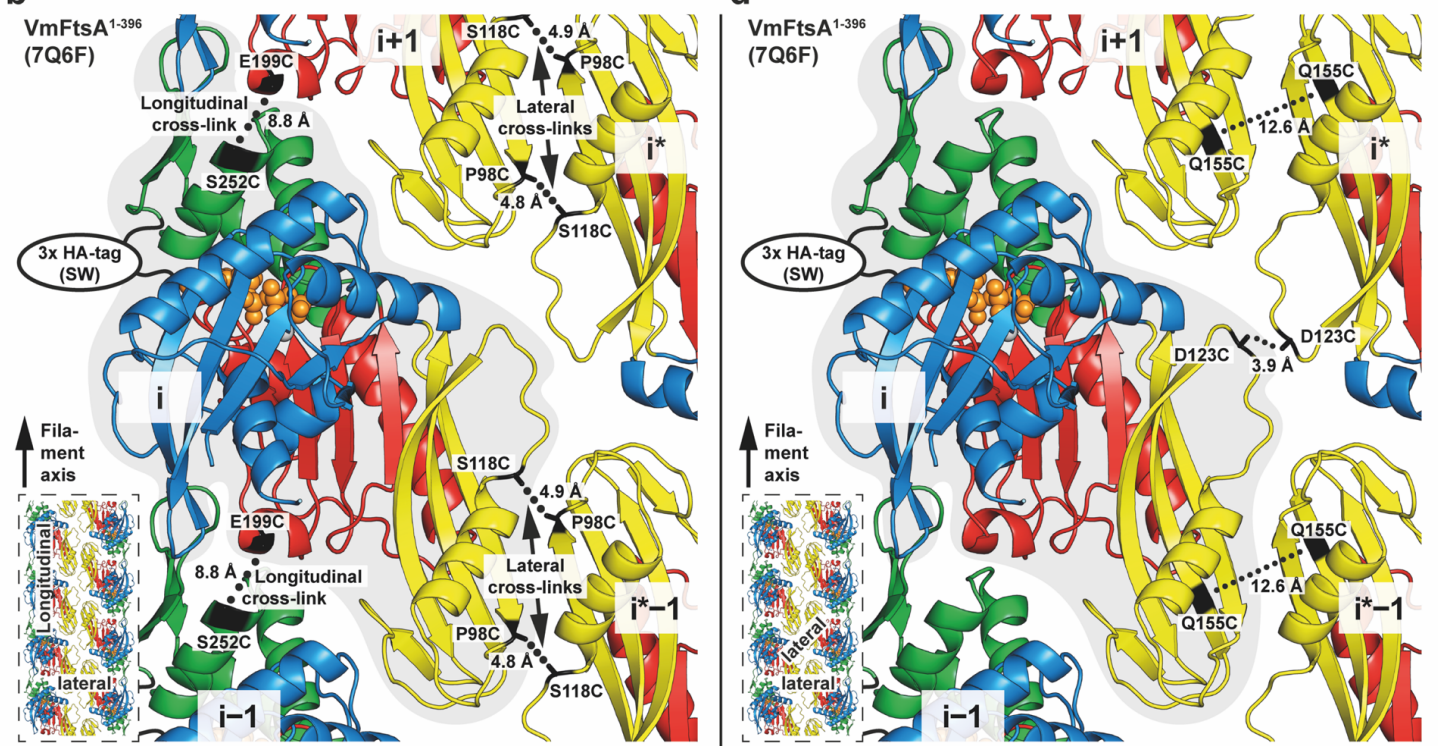

+ BMOE

- BMOE

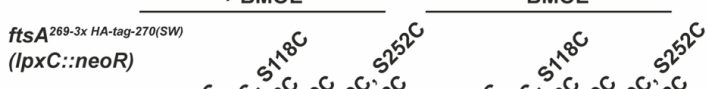

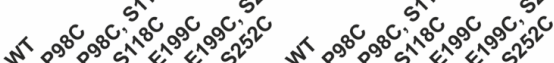
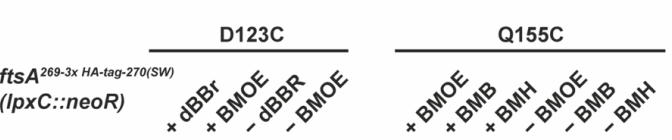

Oligomers

Dimers $\quad-\quad=\begin{aligned} & -180- \\ & -130-\end{aligned}$

Monomer $\overline{\text { Lateral }} \frac{\text { Longitudinal }_{\text {Western Blot: } \alpha-H A-H R P}^{-40-}}{-70-}$

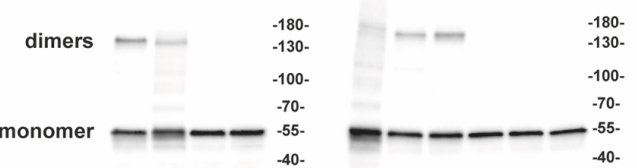

Western Blot: $\alpha-H A-H R P$

Western Blot: $\alpha$-HA-HRP

f

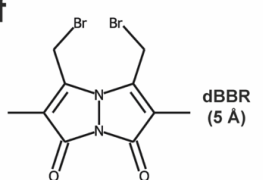<smiles>O=C1C=CC(=O)C1CCC1C(=O)C=CC1=O</smiles><smiles>O=C1C=CC(=O)C1CCCCC1C(=O)C=CC1=O</smiles><smiles>O=C1CCC(=O)C1CCCCCCC1C(=O)CCC1=O</smiles> 
bioRxiv preprint doi: https://doi.org/10.1101/2021.11.08.467742; this version posted November 8, 2021. The copyright holder for this preprint (which was not certified by peer review) is the author/funder, who has granted bioRxiv a license to display the preprint in perpetuity. It is made available under aCC-BY 4.0 International license.

FtsA-FtsN antiparallel double filaments

Nierhaus 2021

Figure 5. Site-specific cysteine-cross-linking in E. coli confirms that FtsA forms antiparallel double filaments in vivo.

a, Schematic overview of the domain architecture of E. coli FtsA (domain boundaries and amino acids positions are the same for $V$. maritimus FtsA). Positions of cysteine mutations and the 3x HA-tag (comprising 40 amino acids including linkers, grey), which was inserted for visualisation via Western blotting, are indicated. Striped areas correspond to residues that are disordered in the $\mathrm{VmFts} \mathrm{A}^{1-396}$ double filament structure (PDB 7Q6F). b, Cysteine mutation pairs fts $A^{3 \times H A, P 98 C, S 118 C}$ and ftsA $A^{3 \times H A, E 199 C,}$ S252C probing the lateral and longitudinal filament interfaces, respectively, are highlighted on the $V m F t s A$ double filament structure (PDB 7Q6F). $\quad C_{\beta}-C_{\beta}$ distances between cysteines are indicated. The position of the 3x HA-tag is also shown. The inset highlights the probed interfaces in the context of the double filament. c, Western blot of cell lysate from FtsA cysteine mutant $E$. coli strains after in vivo cysteine crosslinking (+ BMOE) or without cross-linking (- BMOE). Signal for covalent FtsA dimers can be detected for the double cysteine mutants probing the lateral (fts $A^{3 \times H A, P 98 C, S 118 C}$ ) and longitudinal (fts ${ }^{3 \times H A, E 199 C, S 252 C}$ ) filament interfaces, but not for the respective single cysteine mutant controls. For the (fts $\left.A^{3 \times H A, E 199 C, ~ s 252 C}\right)$ mutant, higher order oligomers can also be detected because of the open symmetry of the longitudinal contact, which leads to chaining. d, Cysteine mutations fts $A^{3 \times H A, D 123 C}$ and fts $A^{3 x} H A, Q 155 C$ probing the lateral $F$ ts $A_{i}-F t s A_{i^{*}}$ and $F t s A_{i}-F t s A_{i^{*}-1}$ filament interfaces, respectively, are highlighted on the VmFtsA double filament structure (PDB 7Q6F). $\mathrm{C}_{\beta}-\mathrm{C}_{\beta}$ distances between cysteines are indicated. Both single cysteine mutations utilise the local C2 symmetry of the respective lateral interface for cross-linking. The position of the 3x HA-tag is also shown. The inset highlights the probed interfaces in the context of the double filament. e, Western blot of cell lysate from FtsA cysteine 
bioRxiv preprint doi: https://doi.org/10.1101/2021.11.08.467742; this version posted November 8,2021 . The copyright holder for this preprint (which was not certified by peer review) is the author/funder, who has granted bioRxiv a license to display the preprint in perpetuity. It is made available under aCC-BY 4.0 International license.

FtsA-FtsN antiparallel double filaments

Nierhaus 2021

mutant E. coli strains after in vivo cysteine cross-linking with thiol-directed crosslinkers of different lengths ("+ cross-linker") or without cross-linking (“- cross-linker"). Signal for a FtsA dimer can be detected after using $\mathrm{dBBr}$ and, to a lesser extent, BMOE cross-linking in the $f t s A^{3 x} H A, D 123 C$ mutant. For the fts $A^{3 x} H A, Q 155 C$ mutation $\left(C_{\beta}-C_{\beta}\right.$ distance $12.6 \AA ̊$ ), FtsA dimers can be detected after cross-linking with $\mathrm{BMB}$ or $\mathrm{BMH}$, but not with BMOE. f, Structures and estimated cross-linking distances for crosslinkers used in this study. $\mathrm{dBBr}$ : dibromobimane, BMOE: bismaleimidoethane, BMB: 1,4-bismaleimidobutane, $\mathrm{BMH}$ : bismaleimidohexane. 
bioRxiv preprint doi: https://doi.org/10.1101/2021.11.08.467742; this version posted November 8,2021 . The copyright holder for this preprint (which was not certified by peer review) is the author/funder, who has granted bioRxiv a license to display the preprint in perpetuity. It is made available under aCC-BY 4.0 International license.

FtsA-FtsN antiparallel double filaments

Nierhaus 2021

a

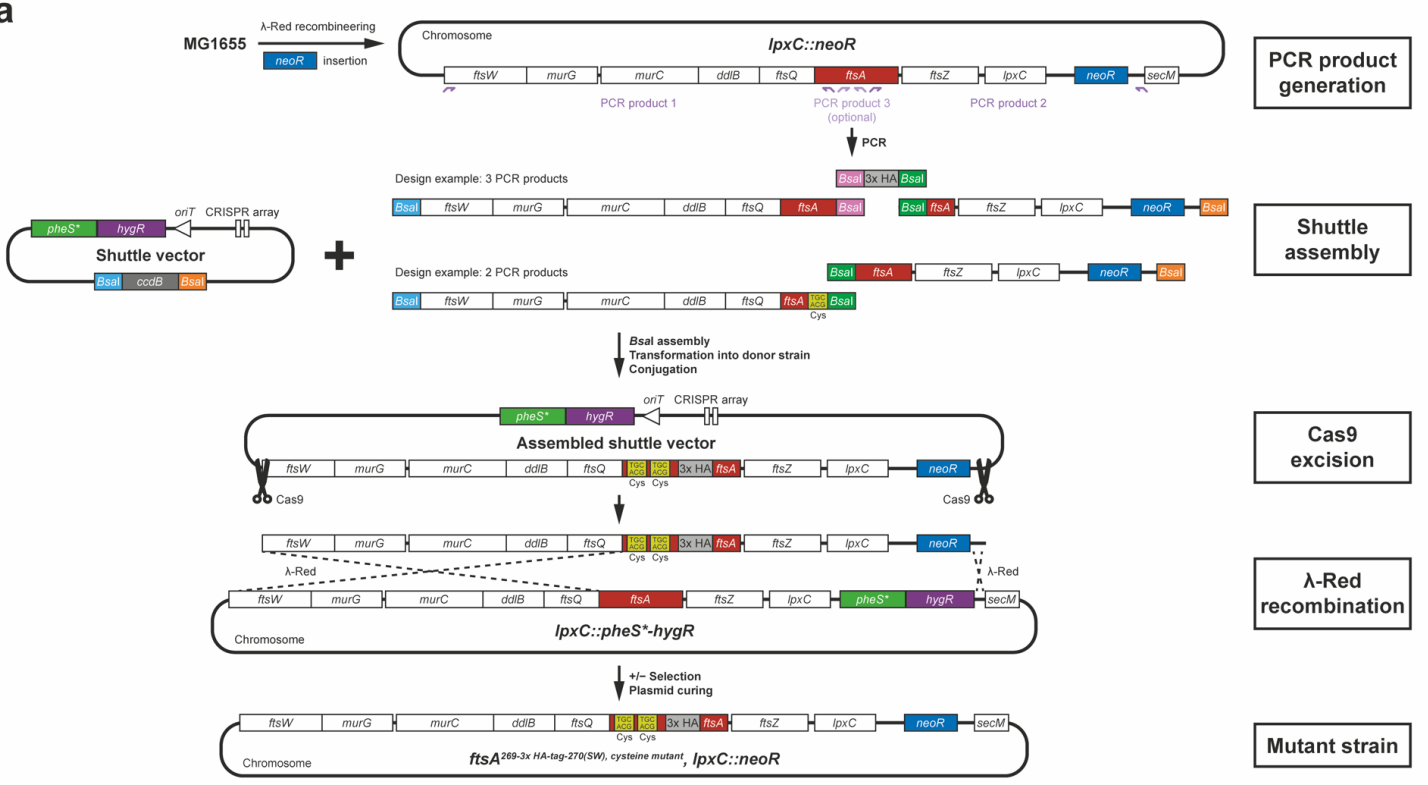

b

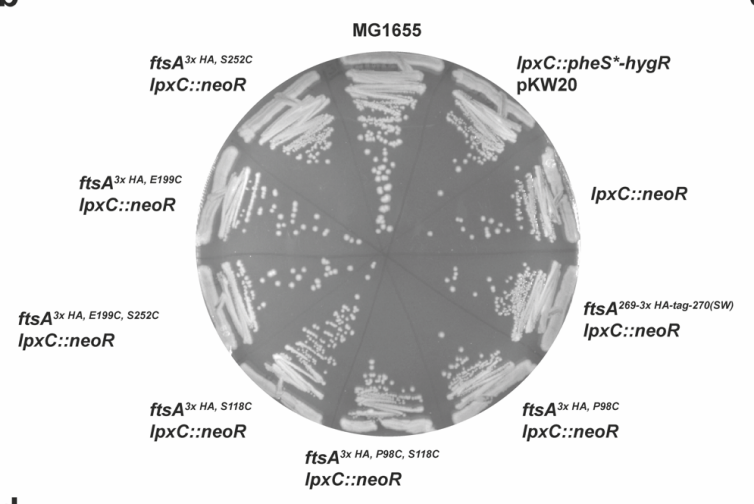

d

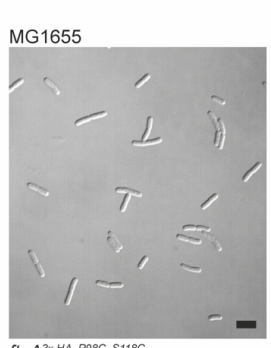

fts $A^{3 \times H A, P 98 C, ~ S 118 C ~}$

IpxC::neoR

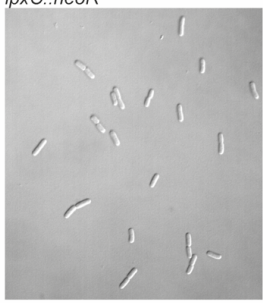

IpxC: phe $S^{*}$-hygR

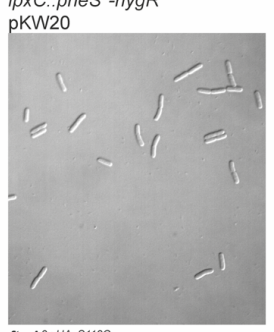

ftsA $3 \times$ HA, S118C

IpXC::neoR

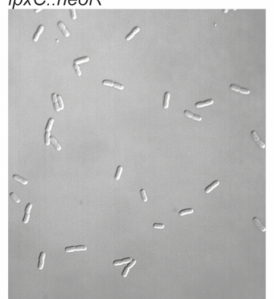

C

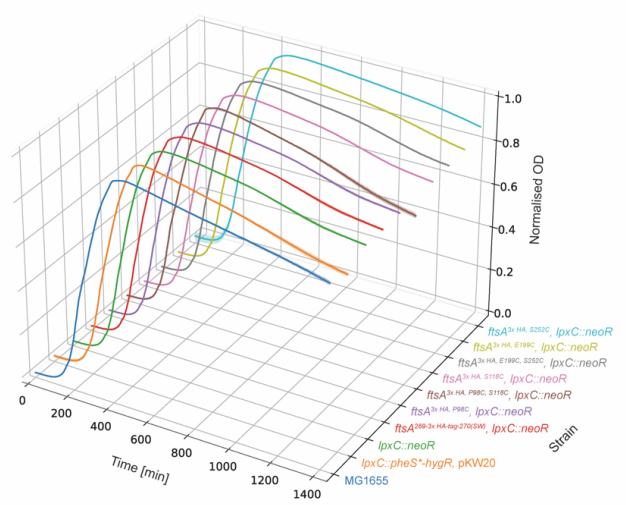

ftsA $A^{3 \times H A}, P 98 \mathrm{C}$

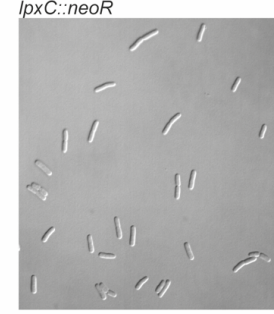

ftsA $A^{3 \times H A, ~ S 252 C ~}$

IpXC::neoR

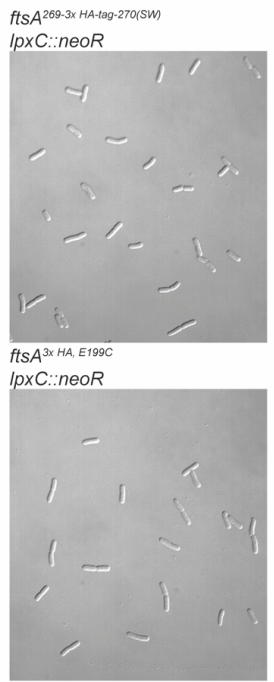

ftSA $A^{3 \times}$ HA, P98C

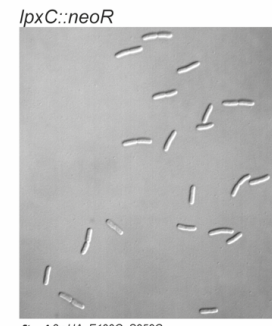

ftsA ${ }^{3 x}$ HA, E199C, S252C

fts $A^{3 \times}$ HA, E199C
IpXC::neoR

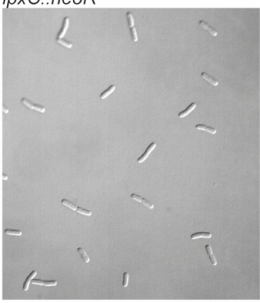


bioRxiv preprint doi: https://doi.org/10.1101/2021.11.08.467742; this version posted November 8,2021 . The copyright holder for this

preprint (which was not certified by peer review) is the author/funder, who has granted bioRxiv a license to display the preprint in perpetuity. It is made available under aCC-BY 4.0 International license.

FtsA-FtsN antiparallel double filaments

Nierhaus 2021

\section{Supplementary Figure S4.}

a, Workflow for REXER 2-based strain construction. PCR products containing the 3x HA-tag or cysteine point mutations were inserted into a shuttle vector by Golden Gate assembly (Engler et al., 2008). Assembled shuttle vectors were transformed into the donor strain, conjugated, and excised in vivo using Cas9. Targeting constructs contain homology regions for $\lambda$-Red mediated recombination into the target locus. Recombinants were selected for neoR and tetR markers and against the phe $S^{*}$ marker. Strains were cured of the helper plasmid pKW20 by growth in absence of selection. $\mathbf{b}$, Growth of strains containing single or double cysteine point mutations and a $3 x \mathrm{HA}-$ tag in the endogenous ftsA gene, and a kanamycin resistance cassette inserted after the IpxC gene. Parent strains and the original MG1655 strain are also shown. c, Growth curves of the same strains in liquid LB medium. Plotted are mean $\pm s d$ (technical octuplicates). d, DIC images of the same strains in exponential phase $\left(\mathrm{OD}_{600}=0.2-0.3\right)$ demonstrating the absence of elongated cells. 
bioRxiv preprint doi: https://doi.org/10.1101/2021.11.08.467742; this version posted November 8,2021 . The copyright holder for this preprint (which was not certified by peer review) is the author/funder, who has granted bioRxiv a license to display the preprint in perpetuity. It is made available under aCC-BY 4.0 International license.

FtsA-FtsN antiparallel double filaments

Nierhaus 2021

a

$\begin{array}{ccc}\begin{array}{c}\text { Unaligned FtsZ } \\ \text { at midcell }\end{array} & \begin{array}{c}\text { Aligned and con- } \\ \text { densed FtsA-FtsZ }\end{array} & \text { Cell constriction }\end{array}$

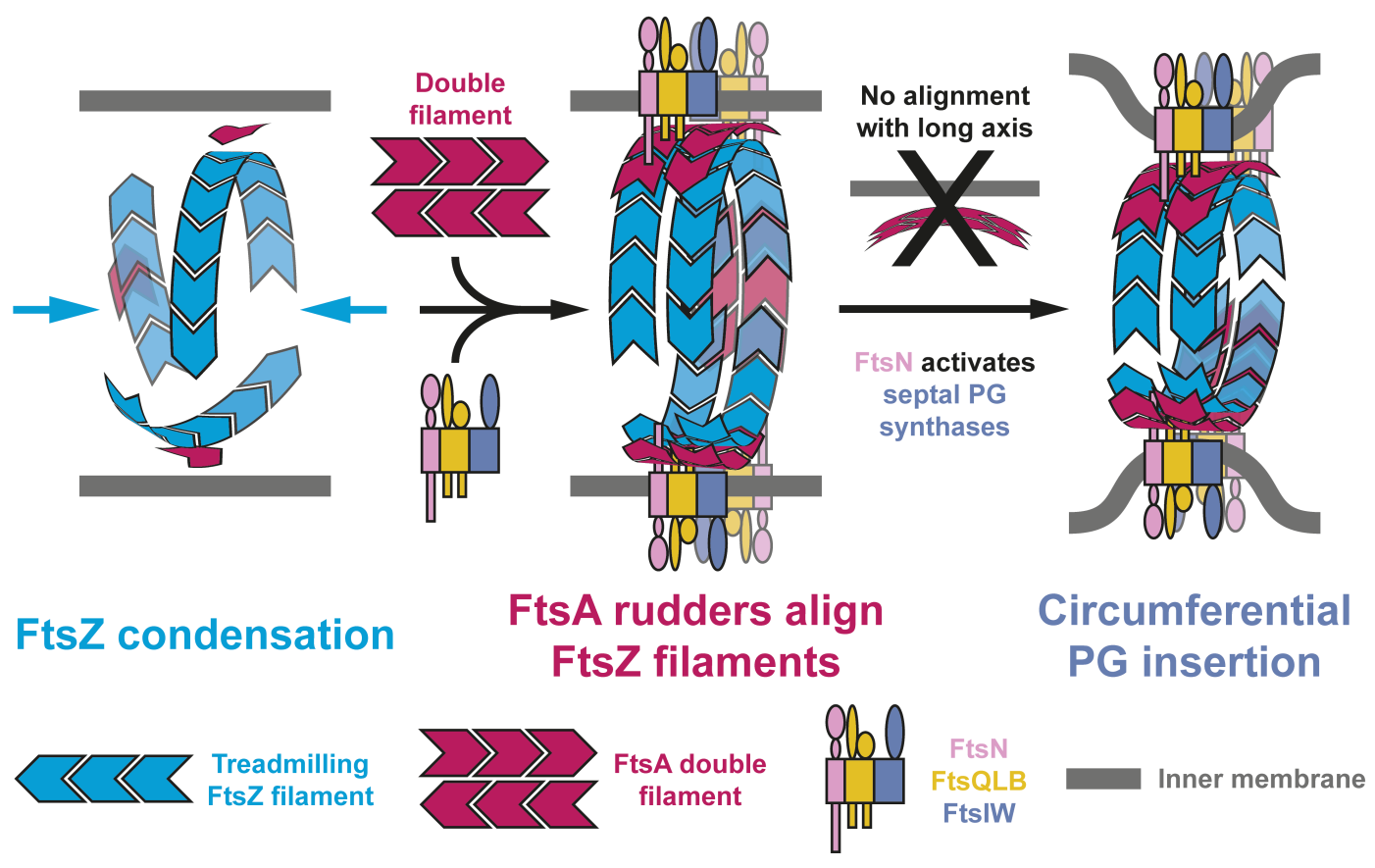

b

Divisome

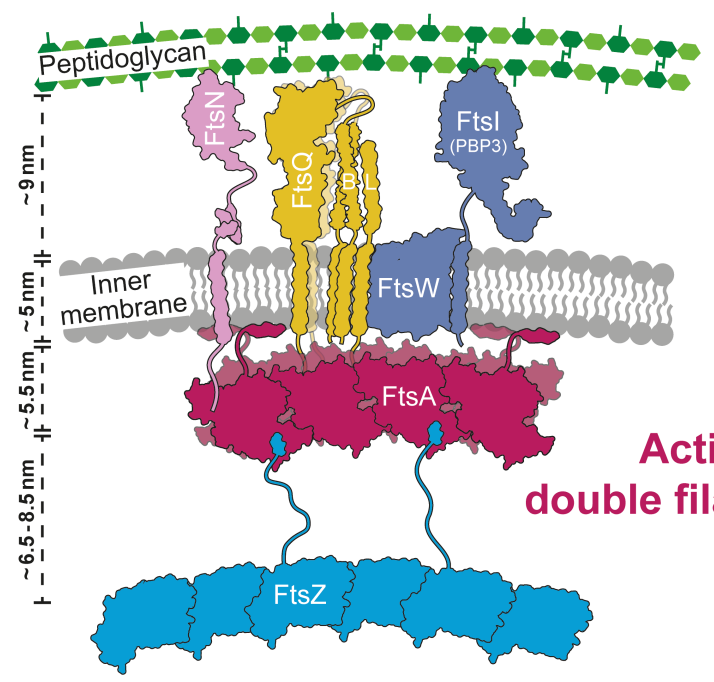

Elongasome (Rod complex)

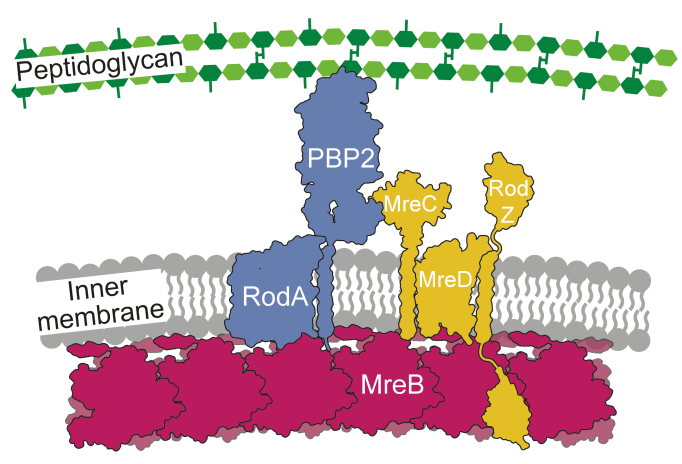

No midcell localisation No constriction 
bioRxiv preprint doi: https://doi.org/10.1101/2021.11.08.467742; this version posted November 8,2021 . The copyright holder for this preprint (which was not certified by peer review) is the author/funder, who has granted bioRxiv a license to display the preprint in perpetuity. It is made available under aCC-BY 4.0 International license.

FtsA-FtsN antiparallel double filaments

Nierhaus 2021

Figure 6. Model for curvature-guided septal PG synthesis and cell constriction mediated by FtsA double filaments.

a, Logical steps towards a divisome primed for curvature-guided septal PG synthesis. The temporal order of events remains to be determined. FtsZ filaments recruited to midcell are unaligned (left). Downstream divisome proteins are recruited and condensed into the narrow midcell plane by treadmilling FtsZ filaments that themselves will also be aligned through their interaction with curvature-sensing FtsA filaments (middle). Condensed complexes are aligned with the short axis of the cell by FtsA double filaments because of their curvature-sensing mechanism, which we propose here they share with MreB. Finally, FtsZ filaments distribute divisome components via treadmilling and might thereby reinforce their alignment with the short axis of the cell. FtsN is required for FtsA double filament formation and activation of septal PG synthases. By coordinating both activities across the inner membrane, FtsN might constitute a synchronising activation switch for the divisome, which allows circumferential synthesis of septal peptidoglycan through the alignment activity, and at the same time cell constriction to commence through the activation of PG synthesis (right). b, Schematic overview of core components of the divisome and elongasome highlighting the evolutionary relationship between the two complexes. We propose here that both complexes utilise the curvature-sensing properties of their cytoplasmic actin double filament scaffolds (red) to direct peptidoglycan synthesis around the cell's circumference. The bipartite PG synthases (FtsWI and RodA-PBP2, purple) are connected to the actin double filaments via integral membrane proteins that serve as structural and regulatory subunits (yellow), or potentially even directly. Unlike the elongasome, the divisome, in $\mathrm{FtsN}$, possesses an additional regulatory subunit that might be necessary since cell division is regulated during the cell cycle. FtsZ is absent 
bioRxiv preprint doi: https://doi.org/10.1101/2021.11.08.467742; this version posted November 8, 2021. The copyright holder for this preprint (which was not certified by peer review) is the author/funder, who has granted bioRxiv a license to display the preprint in perpetuity. It is made available under aCC-BY 4.0 International license.

FtsA-FtsN antiparallel double filaments

Nierhaus 2021

in the elongasome. FtsZ localises the divisome and its activities to midcell and probably more importantly into a narrow plane, an activity that is neither required nor desired in the elongasome. 
bioRxiv preprint doi: https://doi.org/10.1101/2021.11.08.467742; this version posted November 8, 2021. The copyright holder for this preprint (which was not certified by peer review) is the author/funder, who has granted bioRxiv a license to display the preprint in perpetuity. It is made available under aCC-BY 4.0 International license.

FtsA-FtsN antiparallel double filaments

Nierhaus 2021

\section{SUPPLEMENTS}

\section{Supplementary Table T 1. Crystallographic data.}

\begin{tabular}{|c|c|c|c|c|}
\hline \multicolumn{5}{|l|}{ Statistics } \\
\hline Sample & Escherichia coli FtsA & Xenorhabdus poinarii FtsA & $\begin{array}{l}\text { Vibrio maritimus FtsA } \\
\text { (double filament) }\end{array}$ & $\begin{array}{l}\text { Vibrio maritimus FtsA and Fts } N^{1-29} \\
\text { (bent tetramers, some with Fts } N^{1-29} \text { density) }\end{array}$ \\
\hline NCBI database ID & AMK99051.1 & WP_045957782.1 & WP_042501243.1 & FtsA: WP_042501243.1, FtsN: WP_042502685.1 \\
\hline Constructs & 1-405, no tag & 1-396, no tag & 1-396, no tag & FtsA: $1-396$, no tag; FtsN: $1-29$, no tag \\
\hline Crystallisation & $7 \mathrm{mg} / \mathrm{ml}, 2 \mathrm{mM}$ ATP; $20 \%$ w/v PEG 4K, & $7 \mathrm{mg} / \mathrm{ml}, 2 \mathrm{mM}$ ATP; $1 \mathrm{M}$ sodium succinate & $5 \mathrm{mg} / \mathrm{ml}, 2 \mathrm{mM}$ ATP; $25.236 \% \mathrm{v} / \mathrm{v}$ & VmFtsA: 3 mg/ml, VmFtsN 1-29: $0.353 \mathrm{~mm}(5 \mathrm{x}$ \\
\hline (sample; crystallisation & 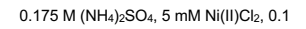 & $\mathrm{pH} 7.0,0.1$ M bis-tris-propane pH 7.0 & PEG 400, $2 \%$ v/v 2-propanol, $0.17 \mathrm{M}$ & molar excess), $2 \mathrm{mM}$ ATP; $21.645 \%$ v/v PEG \\
\hline condition) & $\begin{array}{c}\text { M Tris/HAc pH 7.5, } 0.017 \mathrm{M} \mathrm{MES} / \mathrm{NaOH} \\
\mathrm{pH} 5.9\end{array}$ & & $\begin{array}{c}\mathrm{MgCl}_{2}, 0.04 \mathrm{M} \mathrm{CaAc}, 0.08 \mathrm{M} \text { Tris/HCl } \\
\mathrm{pH} 8.5,0.02 \mathrm{M} \mathrm{MES} / \mathrm{NaOH} \mathrm{pH} 6.0\end{array}$ & $600,0.125 \mathrm{M} \mathrm{MgCl}, 0.1 \mathrm{M} \mathrm{Tris/} / \mathrm{HCl} \mathrm{pH} 8.5$ \\
\hline Cryoprotectant & $\begin{array}{c}20 \% \text { w/v PEG } 4 \mathrm{~K}, 0.262 \mathrm{M}\left(\mathrm{NH}_{4}\right)_{2} \mathrm{SO}_{4}, 5 \\
\mathrm{mM} \mathrm{Ni(II)Cl}, 0.1 \mathrm{M} \mathrm{Tris} / \mathrm{HAc} \mathrm{pH} .5 \\
0.011 \mathrm{M} \mathrm{MES} / \mathrm{NaOH} \text { pH } 5.9,25 \% \\
\text { glycerol }\end{array}$ & reservoir solution $+25 \%$ glycerol & $\begin{array}{c}2 \mathrm{mM} \mathrm{ATP}, 31.545 \% \text { v/v PEG 400, } \\
0.212 \mathrm{M} \mathrm{MgCl}, 0.1 \mathrm{M} \text { Tris//HCl pH } 8.5, \\
0.1 \mathrm{M} \mathrm{KCl}, 5 \mathrm{mM} \text { TCEP, } 20 \% \text { glycerol }\end{array}$ & $\begin{array}{c}0.353 \mathrm{mM} \text { VmFts N } 1-29,2 \mathrm{mM} \text { ATP, } 22.518 \% \text { v/v } \\
\text { PEG 600, } 0.129 \mathrm{M} \mathrm{MgCl}, 0.1 \mathrm{M} \mathrm{Tris} / \mathrm{HCl} \mathrm{pH} 8.5 \\
0.1 \mathrm{M} \mathrm{KCl}, 5 \mathrm{mM} \text { TCEP, } 20 \% \text { glycerol, } 2 \mathrm{mM} \\
\text { EMTS (soaked for } 1 \mathrm{~h} \text { ) }\end{array}$ \\
\hline \multicolumn{5}{|l|}{ Method } \\
\hline Method & crystallography & crystallography & crystallography & crystallography \\
\hline \multirow[t]{3}{*}{ Phasing } & MR & MR & MR & MR \\
\hline & model 3WQT without IC domain, & model 7Q6D & model 7Q6D & model 7Q6F, \\
\hline & which later was added manually & & & then dimer from first Phaser run \\
\hline \multicolumn{5}{|l|}{ Data collection } \\
\hline Beamline & DLS 104 & DLS 104 & DLS 103 & DLS 104 \\
\hline Wavelength (§̊) & 0.97948 & 1.00915 & 0.97625 & 1.00915 \\
\hline \multicolumn{5}{|l|}{ Crystal } \\
\hline Space / point group & $\mathrm{P} 22_{1}$ & $\mathrm{C} 2$ & $\mathrm{P} 22_{1}$ & $\mathrm{P} 22_{1}$ \\
\hline $\operatorname{Cell}\left(\AA ;{ }^{\circ}\right)$ & $51.1,64.2,65.3 ; 96.1$ & $142.2,70.7,50.8 ; 101.0$ & $48.6,109.8,92.6 ; 102.1$ & $98.8,119.9,330.9 ; 93.81$ \\
\hline \multicolumn{5}{|l|}{ Data } \\
\hline Resolution ( $(\AA)$ & 2.7 & 2.8 & 3.3 & 3.6 \\
\hline Completeness $(\%)^{1}$ & 99.8 (99.9) & 99.9 (99.9) & $99.4(99.0)$ & $100.0(100.0)$ \\
\hline Multiplicity ${ }^{1}$ & $3.4(3.4)$ & $3.4(3.0)$ & $6.9(6.4)$ & $6.9(7.1)$ \\
\hline$(\mathrm{I}) / \sigma(I)^{1}$ & $6.8(1.4)$ & $4.4(1.1)$ & $5.9(2.2)$ & $8.6(1.8)$ \\
\hline$R_{\text {merge }}{ }^{1}$ & $0.142(0.863)$ & $0.257(0.857)$ & $0.297(1.309)$ & $0.163(1.197)$ \\
\hline $\mathrm{R}_{\mathrm{pim}}{ }^{1}$ & $0.091(0.552)$ & $0.165(0.584)$ & $0.120(0.544)$ & $0.067(0.489)$ \\
\hline $\mathrm{CC} 1 / 2$ & $0.991(0.659)$ & $0.796(0.636)$ & $0.978(0.954)$ & $0.997(0.983)$ \\
\hline \multicolumn{5}{|l|}{ Refinement } \\
\hline$R /$ Rree $^{2}$ & $0.217 / 0.269$ & $0.218 / 0.260$ & $0.230 / 0.269$ & $0.239 / 0.285$ \\
\hline \multirow[t]{8}{*}{ Models } & $1 \mathrm{FtsA}$ monomer/ASU: & $1 \mathrm{FtsA}$ monomer/ASU: & $2 \mathrm{FtsA}$ monomers/ASU: & $16 \mathrm{FtsA}$ monomers and \\
\hline & & & & $\begin{array}{l}\text { modelled backbones for } 2 \mathrm{FtsN}^{1-29} \\
\text { monomers/ASU: }\end{array}$ \\
\hline & A: $6-388$ & A: 5-392 & A: 8-389 & FtsA: A, C, E-P: 8-389, B: 7-389, D: 8-269, 290- \\
\hline & & & B: 8-389 & 389 \\
\hline & & & & FtsN1-29: X-Y: polyAla1-8 (refined as M1-R8) \\
\hline & & & & 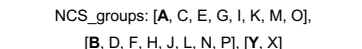 \\
\hline & & & & $\begin{array}{c}\text { (FtsN 1-29 density: strong: A, C; weak: E, G, I, K, M, } \\
\text { O; none: B, D, F, H, J, L, N, P) }\end{array}$ \\
\hline & 1 ATP, $1 \mathrm{Mg}, 3 \mathrm{Ni}$, no waters & $1 \mathrm{ADP}, 1 \mathrm{Mg}$, no waters & 2 ATP, $2 \mathrm{Mg}$, no waters & 16 ATP, 16 Mg, no waters \\
\hline Bond length rmsd (§̊) & 0.003 & 0.002 & 0.002 & 0.004 \\
\hline Bond angle rmsd $\left({ }^{\circ}\right)$ & 0.511 & 0.538 & 0.632 & 0.755 \\
\hline Favoured $(\%)^{3}$ & 99.1 & 99.7 & 100.0 & 99.2 \\
\hline Disallowed $(\%)^{3}$ & 0.0 & 0.0 & 0.0 & 0.0 \\
\hline MOLPROBITY score & 99th percentile & 100th percentile & 100th percentile & 100th percentile \\
\hline PDB IDs & $7 Q 6 \mathrm{D}$ & $7 \mathrm{Q6G}$ & $7 \mathrm{Q6F}$ & $7 Q 61$ \\
\hline
\end{tabular}

1 Values in parentheses refer to the highest recorded resolution shell. ${ }^{2} 5 \%$ of reflections were randomly selected before refinement. ${ }^{3}$ Percentage of residues in the Ramachandran plot (CCP4 PROCHECK: "most favoured" and "additionally allowed" added together). ${ }^{4}$ Data collection was optimised for a native dataset, not SAD. Some density for mercury is however observed at C347 for chains A-F, H, J-L, N, P. The mercury density was used to verify the solution obtained by molecular replacement. 
bioRxiv preprint doi: https://doi.org/10.1101/2021.11.08.467742; this version posted November 8, 2021. The copyright holder for this preprint (which was not certified by peer review) is the author/funder, who has granted bioRxiv a license to display the preprint in perpetuity. It is made available under aCC-BY 4.0 International license.

FtsA-FtsN antiparallel double filaments

Nierhaus 2021

\section{Supplementary Table T 2. Plasmids.}

\begin{tabular}{|c|c|c|c|}
\hline ID & Plasmid & Features & Source \\
\hline \multirow[t]{2}{*}{ pFB483 } & pCONEX-Gate4 & Shuttle plasmid for targeting the ftsA locus ranging & This study \\
\hline & CRISPR(ftsW secM) ccdB & from ftsW to secM (Bsal acceptor) & \\
\hline pJF146 & RK24 lux apR bsd & Conjugative plasmid, NCBI ID: MN927219.1 & (Fredens et al., 2019) \\
\hline \multirow[t]{2}{*}{ pKW20 } & Para lambda-red cas9 & REXER helper plasmid, NCBI ID: MN927219.1 & (Wang et al., 2016) \\
\hline & tetR tracrRNA & & \\
\hline \multirow[t]{2}{*}{ pTN_AN_001 } & $\mathrm{pTXB1}(\mathrm{C} 12 \mathrm{H}) \mathrm{EcFtsA}$ & Expression plasmid for EcFtsA-intein-CBD-12H & This study \\
\hline & & under T7 promotor & \\
\hline \multirow[t]{2}{*}{ pTN_AN_003 } & pTXB1(C12H) EcFtsA ${ }^{\mathrm{E} 124 \mathrm{~A}}$ & Expression plasmid for EcFtsA ${ }^{E 124 A}$-intein-CBD- & This study \\
\hline & & $12 \mathrm{H}$ under $\mathrm{T} 7$ promotor & \\
\hline \multirow[t]{2}{*}{ pTN_AN_004 } & pTXB1 $(\mathrm{C} 12 \mathrm{H}) \mathrm{EcFts} \mathrm{A}^{1143 \mathrm{~L}}$ & Expression plasmid for EcFtsA ${ }^{1143 L}$-intein-CBD-12H & This study \\
\hline & & under T7 promotor & \\
\hline \multirow[t]{2}{*}{ pTN_AN_005 } & pTXB1 $(\mathrm{C} 12 \mathrm{H})$ & Expression plasmid for EcFtsA ${ }^{R 286 \mathrm{~W}} / \mathrm{EcF} \mathrm{Fts} \mathrm{A}^{*}-$ & This study \\
\hline & EcFtsA ${ }^{\text {R286W/EcFtsA* }}$ & intein-CBD-12H under $\mathrm{T} 7$ promotor & \\
\hline \multirow[t]{2}{*}{ pTN_AN_022 } & pOPINS EcFtsA ${ }^{1-405}$ & Expression plasmid for $6 \mathrm{H}-\mathrm{SUMO}-\mathrm{EcFts}^{1-405}$ & This study \\
\hline & & under T7 promotor & \\
\hline pTN_AN_024 & pTXB1(C12H) EcFtsA ${ }^{G 50 E}$ & $\begin{array}{l}\text { Expression plasmid for EcFtsA }{ }^{\mathrm{G} 50 \mathrm{E}} \text {-intein-CBD-12H } \\
\text { under } \mathrm{T7} \text { promotor }\end{array}$ & This study \\
\hline pTN_AN_050 & pOPINS XpFtsA ${ }^{1-396}$ & $\begin{array}{l}\text { Expression plasmid for } 6 \mathrm{H}-\mathrm{SUMO}-\mathrm{XpFts} \mathrm{A}^{1-396} \\
\text { under T7 promotor }\end{array}$ & This study \\
\hline pTN_AN_052 & pOPINS VmFtsA ${ }^{1-396}$ & $\begin{array}{l}\text { Expression plasmid for } 6 \mathrm{H}-\mathrm{SUMO}-\mathrm{VmFts} \mathrm{A}^{1-396} \\
\text { under } \mathrm{T7} \text { promotor }\end{array}$ & This study \\
\hline pTN_AN_057 & pTXB1 $(\mathrm{C} 12 \mathrm{H}) \mathrm{VmFtsA}$ & $\begin{array}{l}\text { Expression plasmid for } \mathrm{VmFtsA} \text {-intein-CBD-12H } \\
\text { under T7 promotor }\end{array}$ & This study \\
\hline \multirow[t]{2}{*}{ pTN_AN_059 } & pTXB1 $(\mathrm{C} 12 \mathrm{H})$ & Expression plasmid for EcFtsA $\mathrm{A}^{\mathrm{M} 96 \mathrm{E}, \mathrm{R} 153 \mathrm{D} \text {-intein- }}$ & This study \\
\hline & EcFtsA ${ }^{\text {M96E, R153D }}$ & $\mathrm{CBD}-12 \mathrm{H}$ under $\mathrm{T} 7$ promotor & \\
\hline \multirow[t]{3}{*}{ pTN_AN_069 } & pOPINSb VmFtsN $N^{1-29}$ & Expression plasmid for $\mathrm{VmFtsN}^{1-29}$-TEV-lipoyl tag- & This study \\
\hline & ENLYFQ & $6 \mathrm{H}$ under $\mathrm{T} 7$ promotor in the pOPINS backbone & \\
\hline & & (6H-SUMO tag was removed) & \\
\hline \multirow[t]{3}{*}{ pTN_AN_071 } & pOPINSb Gly-Gly- & Expression plasmid for $6 \mathrm{H}$-lipoyl tag-TEV-G- & This study \\
\hline & VmFtsN $\mathrm{N}^{2-29}$ & VmFtsN ${ }^{2-29}$ under T7 promotor in the pOPINS & \\
\hline & & backbone (6H-SUMO tag was removed) & \\
\hline \multirow[t]{2}{*}{ pTN_AN_901 } & pET-24b(+) 6H-TEV & Expression plasmid for $6 \mathrm{H}-\mathrm{TEV}$ (PolG* catalytic & Aricescu lab, MRC \\
\hline & & domain) under tac promotor & LMB \\
\hline \multirow[t]{2}{*}{ pTN_AN_902 } & pGEX-6p-1 GST-SENP1 & Expression plasmid for GST-SENP1 (C-terminal & (van den Ent et al., \\
\hline & & catalytic domain) under tac promotor & 2014) \\
\hline
\end{tabular}


bioRxiv preprint doi: https://doi.org/10.1101/2021.11.08.467742; this version posted November 8,2021 . The copyright holder for this preprint (which was not certified by peer review) is the author/funder, who has granted bioRxiv a license to display the preprint in perpetuity. It is made available under aCC-BY 4.0 International license.

FtsA-FtsN antiparallel double filaments

Nierhaus 2021

\section{Supplementary Table T 3. Protein sequences.}

EcFtsA: Escherichia coli MG1655 FtsA, NCBI ID: AMK99051.1

EcFtsN: Escherichia coli MG1655 FtsA, NCBI ID: NP_418368.1

VmFtsA: Vibrio maritimus FtsA, NCBI ID: WP_042501243.1

VmFtsN: Vibrio maritimus FtsA, NCBI ID: WP_042502685.1

XpFtsA: Xenorhabdus poinarii G6 FtsA, NCBI ID: WP_045957782.1

Cleavage sites are marked with "I/l", with the target protein sequence after cleavage highlighted in bold. Mutations from wildtype are underlined.

\section{EcFtsA from EcFtsA-intein-CBD-12H (pTN_AN_001)}

MIKATDRKLVVGLEIGTAKVAALVGEVLPDGMVNIIGVGSCPSRGMDKGGVNDLESVVKCVQRAIDQAELMAD CQISSVYLALSGKHISCQNEIGMVPISEEEVTQEDVENVVHTAKSVRVRDEHRVLHVIPQEYAIDYQEGIKNPVGL SGVRMQAKVHLITCHNDMAKNIVKAVERCGLKVDQLIFAGLASSYSVLTEDERELGVCVVDIGGGTMDIAVYTG GALRHTKVIPYAGNVVTSDIAYAFGTPPSDAEAIKVRHGCALGSIVGKDESVEVPSVGGRPPRSLQRQTLAEVIE PRYTELLNLVNEEILQLQEKLRQQGVKHHLAAGIVLTGGAAQIEGLAACAQRVFHTQVRIGAPLNITGLTDYAQE PYYSTAVGLLHYGKESHLNGEAEVEKRVTASVGSWIKRLNSWLRKEF///CITGDALVALPEGESVRIADIVPGAR PNSDNAIDLKVLDRHGNPVLADRLFHSGEHPVYTVRTVEGLRVTGTANHPLLCLVDVAGVPTLLWKLIDEIKPGDY AVIQRSAFSVDCAGFARGKPEFAPTTYTVGVPGLVRFLEAHHRDPDAQAIADELTDGRFYYAKVASVTDAGVQP VYSLRVDTADHAFITNGFVSHATGLTGLNSGLTTNPGVSAWQVNTAYTAGQLVTYNGKTYKCLQPHTSLAGWEP SNVPALWQLQGSSGGHHHHHHHHHHHH

\section{EcFtsA ${ }^{E 124 A}$ from EcFtsA ${ }^{E 124 A}$-intein-CBD-12H (pTN_AN_003)}

MIKATDRKLVVGLEIGTAKVAALVGEVLPDGMVNIIGVGSCPSRGMDKGGVNDLESVVKCVQRAIDQAELMAD CQISSVYLALSGKHISCQNEIGMVPISEEEVTQEDVENVVHTAKSVRVRDAHRVLHVIPQEYAIDYQEGIKNPVGL SGVRMQAKVHLITCHNDMAKNIVKAVERCGLKVDQLIFAGLASSYSVLTEDERELGVCVVDIGGGTMDIAVYTG GALRHTKVIPYAGNVVTSDIAYAFGTPPSDAEAIKVRHGCALGSIVGKDESVEVPSVGGRPPRSLQRQTLAEVIE PRYTELLNLVNEEILQLQEKLRQQGVKHHLAAGIVLTGGAAQIEGLAACAQRVFHTQVRIGAPLNITGLTDYAQE PYYSTAVGLLHYGKESHLNGEAEVEKRVTASVGSWIKRLNSWLRKEF///CITGDALVALPEGESVRIADIVPGAR PNSDNAIDLKVLDRHGNPVLADRLFHSGEHPVYTVRTVEGLRVTGTANHPLLCLVDVAGVPTLLWKLIDEIKPGDY AVIQRSAFSVDCAGFARGKPEFAPTTYTVGVPGLVRFLEAHHRDPDAQAIADELTDGRFYYAKVASVTDAGVQP VYSLRVDTADHAFITNGFVSHATGLTGLNSGLTTNPGVSAWQVNTAYTAGQLVTYNGKTYKCLQPHTSLAGWEP SNVPALWQLQGSSGGHHHHHHHHHHHH

\section{EcFts $A^{I 143 L}$ from EcFtsA ${ }^{l 143 L}$-intein-CBD-12H (pTN_AN_004)}

MIKATDRKLVVGLEIGTAKVAALVGEVLPDGMVNIIGVGSCPSRGMDKGGVNDLESVVKCVQRAIDQAELMAD CQISSVYLALSGKHISCQNEIGMVPISEEEVTQEDVENVVHTAKSVRVRDEHRVLHVIPQEYAIDYQEGLKNPVG LSGVRMQAKVHLITCHNDMAKNIVKAVERCGLKVDQLIFAGLASSYSVLTEDERELGVCVVDIGGGTMDIAVYT GGALRHTKVIPYAGNVVTSDIAYAFGTPPSDAEAIKVRHGCALGSIVGKDESVEVPSVGGRPPRSLQRQTLAEVI EPRYTELLNLVNEEILQLQEKLRQQGVKHHLAAGIVLTGGAAQIEGLAACAQRVFHTQVRIGAPLNITGLTDYAQ EPYYSTAVGLLHYGKESHLNGEAEVEKRVTASVGSWIKRLNSWLRKEF//CITGDALVALPEGESVRIADIVPGA RPNSDNAIDLKVLDRHGNPVLADRLFHSGEHPVYTVRTVEGLRVTGTANHPLLCLVDVAGVPTLLWKLIDEIKPGD YAVIQRSAFSVDCAGFARGKPEFAPTTYTVGVPGLVRFLEAHHRDPDAQAIADELTDGRFYYAKVASVTDAGVQ 
bioRxiv preprint doi: https://doi.org/10.1101/2021.11.08.467742; this version posted November 8,2021 . The copyright holder for this preprint (which was not certified by peer review) is the author/funder, who has granted bioRxiv a license to display the preprint in perpetuity. It is made available under aCC-BY 4.0 International license.

FtsA-FtsN antiparallel double filaments

Nierhaus 2021

PVYSLRVDTADHAFITNGFVSHATGLTGLNSGLTTNPGVSAWQVNTAYTAGQLVTYNGKTYKCLQPHTSLAGWE PSNVPALWQLQGSSGGHHHHHHHHHHHH

\section{EcFtsA $A^{R 286 \mathrm{~W}} /$ EcFtsA* from EcFtsA ${ }^{R 286 \mathrm{~W}}$-intein-CBD-12H (pTN_AN_005)}

MIKATDRKLVVGLEIGTAKVAALVGEVLPDGMVNIIGVGSCPSRGMDKGGVNDLESVVKCVQRAIDQAELMAD CQISSVYLALSGKHISCQNEIGMVPISEEEVTQEDVENVVHTAKSVRVRDEHRVLHVIPQEYAIDYQEGIKNPVGL SGVRMQAKVHLITCHNDMAKNIVKAVERCGLKVDQLIFAGLASSYSVLTEDERELGVCVVDIGGGTMDIAVYTG GALRHTKVIPYAGNVVTSDIAYAFGTPPSDAEAIKVRHGCALGSIVGKDESVEVPSVGGRPPWSLQRQTLAEVI EPRYTELLNLVNEEILQLQEKLRQQGVKHHLAAGIVLTGGAAQIEGLAACAQRVFHTQVRIGAPLNITGLTDYAQ EPYYSTAVGLLHYGKESHLNGEAEVEKRVTASVGSWIKRLNSWLRKEF//CITGDALVALPEGESVRIADIVPGA RPNSDNAIDLKVLDRHGNPVLADRLFHSGEHPVYTVRTVEGLRVTGTANHPLLCLVDVAGVPTLLWKLIDEIKPGD YAVIQRSAFSVDCAGFARGKPEFAPTTYTVGVPGLVRFLEAHHRDPDAQAIADELTDGRFYYAKVASVTDAGVQ PVYSLRVDTADHAFITNGFVSHATGLTGLNSGLTTNPGVSAWQVNTAYTAGQLVTYNGKTYKCLQPHTSLAGWE PSNVPALWQLQGSSGGHHHHHHHHHHHH

\section{EcFtsA ${ }^{G 50 E}$ from EcFtsA ${ }^{G 50 E}$-intein-CBD-12H (pTN_AN_024)}

MIKATDRKLVVGLEIGTAKVAALVGEVLPDGMVNIIGVGSCPSRGMDKGEVNDLESVVKCVQRAIDQAELMAD CQISSVYLALSGKHISCQNEIGMVPISEEEVTQEDVENVVHTAKSVRVRDËHRVLHVIPQEYAIDYQEGIKNPVGL SGVRMQAKVHLITCHNDMAKNIVKAVERCGLKVDQLIFAGLASSYSVLTEDERELGVCVVDIGGGTMDIAVYTG GALRHTKVIPYAGNVVTSDIAYAFGTPPSDAEAIKVRHGCALGSIVGKDESVEVPSVGGRPPRSLQRQTLAEVIE PRYTELLNLVNEEILQLQEKLRQQGVKHHLAAGIVLTGGAAQIEGLAACAQRVFHTQVRIGAPLNITGLTDYAQE PYYSTAVGLLHYGKESHLNGEAEVEKRVTASVGSWIKRLNSWLRKEF//CITGDALVALPEGESVRIADIVPGAR PNSDNAIDLKVLDRHGNPVLADRLFHSGEHPVYTVRTVEGLRVTGTANHPLLCLVDVAGVPTLLWKLIDEIKPGDY AVIQRSAFSVDCAGFARGKPEFAPTTYTVGVPGLVRFLEAHHRDPDAQAIADELTDGRFYYAKVASVTDAGVQP VYSLRVDTADHAFITNGFVSHATGLTGLNSGLTTNPGVSAWQVNTAYTAGQLVTYNGKTYKCLQPHTSLAGWEP SNVPALWQLQGSSGGHHHHHHHHHHHH

\section{VmFtsA from VmFtsA-intein-CBD-12H (pTN_AN_057)}

MTKTTDDNIIVGLDIGTATVSALVGEVLPDGQVNIIGAGSSPSRGMDKGGVNDLESVVKSVQRAVDQAELMAEC QISSVFISLSGKHIASRIEKGMGTISEEEVSQDDMDRAIHTAKSIKIGDEQRILHVIPQEFTIDYQEGIKNPLGLSGV RMEVSVHLISCHNDMARNIIKAVERCGLKVEQLVFSGLASSNAVITEDERELGVCVVDIGAGTMDISIWTGGALR HTEVFSYAGNAVTSDIAFAFGTPLSDAEEIKVKYGCALSELVSKDDTVNVPSVGGRPSRSLQRQTLAEVIEPRYT ELMGLVNQTIDNVQAKLRENGVKHHLAAGVVLTGGAAQIEGVVECAERVFRNQVRVGKPLEVSGLTDYVKEPY HSTAVGLLHYARDSQDNDDNDYNEPKRQSVSTIFGKLRNWIQKEF///CITGDALVALPEGESVRIADIVPGARPN SDNAIDLKVLDRHGNPVLADRLFHSGEHPVYTVRTVEGLRVTGTANHPLLCLVDVAGVPTLLWKLIDEIKPGDYAV IQRSAFSVDCAGFARGKPEFAPTTYTVGVPGLVRFLEAHHRDPDAQAIADELTDGRFYYAKVASVTDAGVQPVY SLLVDTADHAFITNGFVSHATGLTGLNSGLTTNPGVSAWQVNTAYTAGQLVTYNGKTYKCLQPHTSLAGWEPSN VPALWQLQGSSGGHHHHHHHHHHHH

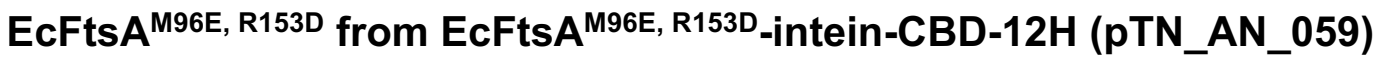

MIKATDRKLVVGLEIGTAKVAALVGEVLPDGMVNIIGVGSCPSRGMDKGGVNDLESVVKCVQRAIDQAELMAD CQISSVYLALSGKHISCQNEIGEVPISEEEVTQEDVENVVHTAKSVRVRDEHRVLHVIPQEYAIDYQEGIKNPVGL SGVDMQAKVHLITCHNDMAKNIVKAVERCGLKVDQLIFAGLASSYSVLTEDERELGVCVVDIGGGTMDIAVYTG GALRHTKVIPYAGNVVTSDIAYAFGTPPSDAEAIKVRHGCALGSIVGKDESVEVPSVGGRPPRSLQRQTLAEVIE PRYTELLNLVNEEILQLQEKLRQQGVKHHLAAGIVLTGGAAQIEGLAACAQRVFHTQVRIGAPLNITGLTDYAQE PYYSTAVGLLHYGKESHLNGEAEVEKRVTASVGSWIKRLNSWLRKEF///CITGDALVALPEGESVRIADIVPGAR PNSDNAIDLKVLDRHGNPVLADRLFHSGEHPVYTVRTVEGLRVTGTANHPLLCLVDVAGVPTLLWKLIDEIKPGDY AVIQRSAFSVDCAGFARGKPEFAPTTYTVGVPGLVRFLEAHHRDPDAQAIADELTDGRFYYAKVASVTDAGVQP VYSLRVDTADHAFITNGFVSHATGLTGLNSGLTTNPGVSAWQVNTAYTAGQLVTYNGKTYKCLQPHTSLAGWEP SNVPALWQLQGSSGHHHHHHHHHHHH 
bioRxiv preprint doi: https://doi.org/10.1101/2021.11.08.467742; this version posted November 8, 2021. The copyright holder for this preprint (which was not certified by peer review) is the author/funder, who has granted bioRxiv a license to display the preprint in perpetuity. It is made available under aCC-BY 4.0 International license.

FtsA-FtsN antiparallel double filaments

Nierhaus 2021

\title{
EcFtsA ${ }^{1-405}$ from 6H-SUMO-EcFtsA ${ }^{1-405}$ (pTN_AN_022)
}

MGSSHHHHHHGSDSEVNQEAKPEVKPEVKPETHINLKVSDGSSEIFFKIKKTTPLRRLMEAFAKRQGKEMDSLRF LYDGIRIQADQTPEDLDMEDNDIIEAHREQIGG///MIKATDRKLVVGLEIGTAKVAALVGEVLPDGMVNIIGVGSCP SRGMDKGGVNDLESVVKCVQRAIDQAELMADCQISSVYLALSGKHISCQNEIGMVPISEEEVTQEDVENVVHTA KSVRVRDEHRVLHVIPQEYAIDYQEGIKNPVGLSGVRMQAKVHLITCHNDMAKNIVKAVERCGLKVDQLIFAGL ASSYSVLTEDERELGVCVVDIGGGTMDIAVYTGGALRHTKVIPYAGNVVTSDIAYAFGTPPSDAEAIKVRHGCAL GSIVGKDESVEVPSVGGRPPRSLQRQTLAEVIEPRYTELLNLVNEEILQLQEKLRQQGVKHHLAAGIVLTGGAA QIEGLAACAQRVFHTQVRIGAPLNITGLTDYAQEPYYSTAVGLLHYGKESHLNGEAEVEKRVTASV

\section{XpFtsA ${ }^{1-396}$ from 6H-SUMO-XpFtsA ${ }^{1-396}$ (pTN_AN_050)}

MGSSHHHHHHGSDSEVNQEAKPEVKPEVKPETHINLKVSDGSSEIFFKIKKTTPLRRLMEAFAKRQGKEMDSLRF LYDGIRIQADQTPEDLDMEDNDIIEAHREQIGG///MIKSTDRKLVVGLEIGTAKVSALVGEILPDGMVNIIGVGNCPS RGMDKGGVNDLESVVKCVQRAIDQAELMADCQISSVYLALSGKHISCQNEIGMVPVSEEEVTQDDVDSVVHTA KSVRVRDEHRILHVIPQEYAIDYQEGIKNPVGLSGVRMQAKVHLITCHNDMAKNIVKAVERCGLKVDQLIFAGLA ASYAVLTEDERELGVCVVDIGGGTMDVAVYTGGALRHTKVIPYAGNVVTSDIAYAFGTPPSDAETIKVRHGCAL GSIVSKDESVEVPSVGGRPPRSLQRQTLAEVIEPRYTELLNLVNDEILRLQEQLRQQGVKHHLAAGIVLTGGGA QIDGLAECAQRVFHTQVRIGRPLNITGLTDYVQAPCYSTAVGLLHYGKESHLGGDSD

\section{VmFtsA ${ }^{1-396}$ from $6 \mathrm{H}-\mathrm{SUMO}-\mathrm{VmFts} \mathrm{A}^{1-396}$ (pTN_AN_052)}

MGSSHHHHHHGSDSEVNQEAKPEVKPEVKPETHINLKVSDGSSEIFFKIKKTTPLRRLMEAFAKRQGKEMDSLRF LYDGIRIQADQTPEDLDMEDNDIIEAHREQIGG///MTKTTDDNIIVGLDIGTATVSALVGEVLPDGQVNIIGAGSSPS RGMDKGGVNDLESVVKSVQRAVDQAELMAECQISSVFISLSGKHIASRIEKGMGTISEEEVSQDDMDRAIHTAK SIKIGDEQRILHVIPQEFTIDYQEGIKNPLGLSGVRMEVSVHLISCHNDMARNIIKAVERCGLKVEQLVFSGLASSN AVITEDERELGVCVVDIGAGTMDISIWTGGALRHTEVFSYAGNAVTSDIAFAFGTPLSDAEEIKVKYGCALSELVS KDDTVNVPSVGGRPSRSLQRQTLAEVIEPRYTELMGLVNQTIDNVQAKLRENGVKHHLAAGVVLTGGAAQIEG VVECAERVFRNQVRVGKPLEVSGLTDYVKEPYHSTAVGLLHYARDSQDNDDND

\section{VmFts ${ }^{1-29}$-ENLYFQ from VmFts ${ }^{1-29}$-TEV-lipoyl tag-6H (pTN_AN_069)}

M¥///ANRDYVRRGKGTSRRPAKKKTSGKKPWRENLYFQ///GGSSGAFEFKLPDIGEGIHEGEIVKWFVKPGDEV NEDDVLCEVQNDKAVVEIPSPVKGKVLEILVPEGTVATVGQTLITLDAPGYENMTTGSDTGSHHHHHH ${ }_{\ddagger} \mathrm{N}$-terminal methionine was cleaved off in vivo according to ESI-TOF mass spectrometry

\author{
Gly-Gly-VmFts N2-29 from 6H-lipoyl tag-TEV-G-VmFtsN2-29 (pTN_AN_071) \\ MGSSHHHHHHSGAFEFKLPDIGEGIHEGEIVKWFVKPGDEVNEDDVLCEVQNDKAVVEIPSPVKGKVLEILVPEG
} TVATVGQTLITLDAPGYENMTTGSDTGSENLYFQ///GGANRDYVRRGKGTSRRPAKKKTSGKKPWR 


\section{Supplementary Table T 4. Fts N peptide sequences.}

\begin{tabular}{|c|c|c|}
\hline Peptide & Sequence & $\mathrm{MW}(\mathrm{Da})$ \\
\hline EcFtsN ${ }^{1-12}$ & MAQRD YVRRS QP & 1506.70 \\
\hline EcFtsN ${ }^{1-22}$ & MAQRD YVRRS QPAPS RRKKS TS & 2605.96 \\
\hline EcFtsN $^{11-32}$ & QPAPS RRKKS TSRKK QRNLP AV & 2533.97 \\
\hline EcFtsN ${ }^{4-26}$ & RD YVRRS QPAPS RRKKS TSRKK Q & 2816.23 \\
\hline EcFtsN $^{1-32}$ & MAQRD YVRRS QPAPS RRKKS TSRKK QRNLP AV & 3797.41 \\
\hline EcFtsN ${ }^{1-32, ~ D 5 N}$ & MAQRN YVRRS QPAPS RRKKS TSRKK QRNLP AV & 3796.42 \\
\hline $\mathrm{EcFtsN}^{1-32, \Delta \mathrm{RK} 1}$ & MAQRD YVAAS QPAPS RRKKS TSRKK QRNLP AV & 3627.19 \\
\hline EcFtsN $^{1-32 ; \Delta R K 2}$ & MAQRD YVRRS QPAPS AASAS TSRKK QRNLP AV & 3529.00 \\
\hline $\mathrm{EcFtsN}^{1-32, \Delta \mathrm{RK} 3}$ & MAQRD YVRRS QPAPS RRKKS TSASA QRNLP AV & 3614.11 \\
\hline EcFtsN $N^{1-32, \Delta R K 2,3}$ & MAQRD YVRRS QPAPS AASAS TSASA QRNLP AV & 3345.70 \\
\hline EcFtsN $^{1-33, \text { scrambled }}$ & SARRK NKRRV RQVRK TAPPQ QDSSP LKAMS RYS & 3884.48 \\
\hline EcFtsN $^{1-32}-\mathrm{C}$ & MAQRD YVRRS QPAPS RRKKS TSRKK QRNLP AVC & 3900.55 \\
\hline VmFtsN ${ }^{1-29}$ & MANRD YVRRG KGTSR RPAKK KTSGK KPWR & 3417.00 \\
\hline VmFtsN $N^{1-29}-\mathrm{C}$ & MANRD YVRRG KGTSR RPAKK KTSGK KPWRC & 3520.14 \\
\hline
\end{tabular}




\section{Supplementary Table T 5. E. coli strains.}

\begin{tabular}{|c|c|c|c|}
\hline Strain & Genotype & Source & WGS* \\
\hline E. coli & F- ompT hsdSB (rB- mB-) gal dcm (DE3); & Lucigen or Sigma & No \\
\hline C41(DE3) & BL21(DE3) derivative & & \\
\hline E. coli MAX & $\mathrm{F}-\varphi 80 / a c Z \Delta \mathrm{M} 15 \Delta($ lacZYA-argF) U169 recA1 & ThermoFisher & No \\
\hline Efficiency & endA1 hsdR17 (rk-, mk+) phoA supE44 $\lambda-$ & & \\
\hline $\mathrm{DH} 5 \mathrm{a}$ & thi-1 gyrA96 relA1 & & \\
\hline MDS42 & $\begin{array}{l}\text { MG1655, } \triangle e n d A, \triangle f h u A B C D \text {, deletion of IS } \\
\text { elements, prophages etc }\end{array}$ & $\begin{array}{l}\text { Chin lab, MRC LMB } \\
\text { (Posfai et al., 2006) }\end{array}$ & No \\
\hline MG1655 & $\mathrm{F}-\lambda-r p h-1 \mathrm{fnr}+$ & DSMZ (DSM 18039) & $r c / C^{G 169 C}$ \\
\hline SFB123 & $\begin{array}{l}\text { MG1655, IpxC::phe } S^{T 251 A, A 294 G}-h y g R, \text { pkW20 } \\
\text { Para lambda-red cas9 tetR tracrRNA }\end{array}$ & This study & $\begin{array}{l}r c / C^{G 169 C} \\
p_{p i D^{D 134 G}}\end{array}$ \\
\hline SFB143 & MDS42, $\Delta$ thiF, pJF146 RK24 lux apR bsd & This study & No \\
\hline SFB148 & $\begin{array}{l}\text { MG1655, IpxC::neoR, pkW20 Para lambda-red } \\
\text { cas9 tetR tracrRNA }\end{array}$ & This study & No \\
\hline sTN001 & MG1655, ftsA ${ }^{269-3 x}$ HA-tag-270(SW), IpxC::neoR & This study & $\begin{array}{l}r c / C^{G 169 C} \\
\operatorname{ppiD}^{D 134 G}\end{array}$ \\
\hline sTN003 & MG1655, ftsA ${ }^{P 98 C,}$ 269-3x HA-tag-270(SW), IpxC::neoR & This study & $\begin{array}{l}r c / C^{G 169 C} \\
\text { ppiD }^{D 134 G}\end{array}$ \\
\hline sTN005 & $\begin{array}{l}\text { MG1655, fts } A^{P 98 C, ~ S 118 C, ~ 269-3 x ~ H A-t a g-270(S W), ~} \\
\text { IpxC::neoR }\end{array}$ & This study & $\begin{array}{l}r c / C^{G 169 C} \\
\operatorname{ppiD}^{D 134 G}\end{array}$ \\
\hline sTN008 & MG1655, ftsA $A^{S 118 C, 269-3 \times \text { HA-tag-27o(SW) }, ~ I p x C:: n e o R}$ & This study & $\begin{array}{l}r c / C^{G 169 C}, \\
p p i D^{D 134 G}\end{array}$ \\
\hline sTN010 & $\begin{array}{l}\text { MG1655, ftsA } A^{E 199 C, ~ S 252 C, ~ 269-3 x ~ H A-t a g-27 o(S W), ~} \\
\text { IpxC::neoR }\end{array}$ & This study & $\begin{array}{l}r c / C^{G 169 C} \\
p_{p i D^{D 134 G}}\end{array}$ \\
\hline sTN011 & MG1655, ftsA ${ }^{E 199 C,}$ 269-3x HA-tag-270(SW), IpxC::neoR & This study & $\begin{array}{l}r c / C^{G 169 C} \\
\operatorname{ppiD}^{D 134 G}\end{array}$ \\
\hline sTN014 & MG1655, ftsA $A^{S 252 C,}$ 269-3x HA-tag-270(SW), IpxC::neoR & This study & $\begin{array}{l}r c / C^{G 169 C} \\
p_{p i D^{D 134 G}}\end{array}$ \\
\hline sTN015 & 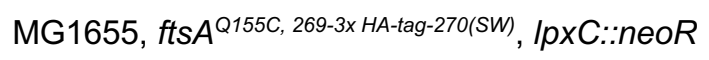 & This study & No \\
\hline sTN017 & MG1655, fts $A^{D 123 C,}$ 269-3x HA-tag-270(SW), IpxC::neoR & This study & No \\
\hline
\end{tabular}

